\title{
Evaluation of Reforestation Efforts on Two Reclaimed Surface Mines in West Virginia
}

\author{
Curtis A. DeLong \\ West Virginia University
}

Follow this and additional works at: https://researchrepository.wvu.edu/etd

\section{Recommended Citation}

DeLong, Curtis A., "Evaluation of Reforestation Efforts on Two Reclaimed Surface Mines in West Virginia" (2010). Graduate Theses, Dissertations, and Problem Reports. 3055.

https://researchrepository.wvu.edu/etd/3055

This Thesis is protected by copyright and/or related rights. It has been brought to you by the The Research Repository @ WVU with permission from the rights-holder(s). You are free to use this Thesis in any way that is permitted by the copyright and related rights legislation that applies to your use. For other uses you must obtain permission from the rights-holder(s) directly, unless additional rights are indicated by a Creative Commons license in the record and/ or on the work itself. This Thesis has been accepted for inclusion in WVU Graduate Theses, Dissertations, and Problem Reports collection by an authorized administrator of The Research Repository @ WVU. For more information, please contact researchrepository@mail.wvu.edu. 


\title{
Evaluation of Reforestation Efforts on Two Reclaimed Surface Mines in West Virginia
}

\author{
Curtis A. DeLong \\ Thesis submitted to \\ College of Agriculture, Natural Resources and Design \\ at West Virginia University \\ in partial fulfillment of the requirements \\ for the degree of \\ Master of Science \\ In \\ Plant and Soil Sciences \\ Dr. Jeffrey G. Skousen, Chair \\ Dr. Eugenia M. Pena-Yewtukhiw \\ Dr. Kathryn B. Piatek \\ Division of Plant and Soil Sciences \\ Morgantown, West Virginia \\ 2010
}

Keywords: surface mine reforestation, unweathered gray sandstone, soil bulk density, herbaceous ground cover, compaction, bark mulch, survival, volume. 


\section{ABSTRACT \\ Evaluation of Reforestation Efforts on \\ Two Reclaimed Surface Mines in West Virginia}

Curtis A. DeLong

Coal mining has disturbed approximately 2.4 million hectares (6 million acres) since 1930 in the United States. West Virginia is located in the Eastern Coal Region where surface mining has disturbed large areas of eastern deciduous forest. As coal operators and land owners are moving toward restoring forests on mined lands, techniques are being developed and tested to increase tree survival and growth to ensure disturbed land is converted back to forest in a timely fashion. To aid in successful reforestation, the Office of Surface Mining Reclamation and Enforcement adopted reclamation techniques called the Forestry Reclamation Approach which provides recommendations on substrate selection, grading, ground covers, tree species selection, and proper tree planting. This study was implemented to provide additional scientific data on the implementation of these techniques especially related to substrate selection. Studies were conducted at Catenary Coal's Samples mine in Kanawha County, WV and ICG Eastern, LLC's Birch River mine in Webster County, WV. Both of these sites have been surface mined for coal and reclaimed using either Commercial Forestry or Forestry post mining land uses. Following FRA guidelines, demonstration plots were constructed at both locations; 2005 at the Samples mine and 2007 at Birch River. Demonstration plots at the Samples mine had treatments of substrate (brown vs. gray), depth of substrate $(1.2 \mathrm{~m}$ vs. $1.5 \mathrm{~m}$ ), and compaction (compacted vs. noncompacted), while plots at Birch River had treatments of substrate (brown vs. gray), bark mulch (with vs. without), and hydroseeding (with vs. without). After final construction of the plots, a mixture of hardwood trees was planted at both sites. The objectives of this research were to assess physical and chemical properties of mine soils after three years at ICG and five years at Samples, and to determine tree volume and survival in various treatment combinations. Gray sandstone substrates at both sites had high $\mathrm{pH}$ ranging from 7.7 to 8.3 while brown substrates $\mathrm{pH}$ ranged from 4.4 to 5.4, which were consistent throughout the study at both sites. After five years at Samples, there were only a few significant changes in soil properties and extractable element concentrations. Electrical conductivity decreased in all treatment combinations with the exception of the $1.2 \mathrm{~m}$ brown sandstone noncompacted (4B-NC) with totals ranging from 0.10 to $0.53 \mathrm{dS} \mathrm{m}^{-1}$ and decreases ranging from 0.10 to $0.40 \mathrm{dS} \mathrm{m}^{-1}$. Extractable potassium concentrations ranged from 0.17 to $0.20 \mathrm{cmol}_{\mathrm{c}} \mathrm{kg}^{-1}$ in 2005 and 0.05 to $0.10 \mathrm{cmol}_{\mathrm{c}} \mathrm{kg}^{-1}$ in 2009 with significant decreases in all treatment combinations. After five growing seasons at Samples, the average survival across all tree species was $66 \%$ with an average volume of $1328 \mathrm{~cm}^{3}$. No significant differences were found for total tree survival between substrate, compaction and depth treatments. Survival by species ranged from $50 \%$ for white pine to $77 \%$ for black locust. Trees in the brown sandstone substrates had significantly greater volume at $1840 \mathrm{~cm}^{3}$ compared to $176 \mathrm{~cm}^{3}$ in the gray sandstone. Black locust significantly outperformed all other species with a volume of $7361 \mathrm{~cm}^{3}$ while the species with the next closest volume was black cherry at $998 \mathrm{~cm}^{3}$. After three years at Birch River, the gray sandstone treatments and treatments with bark mulch had a soil $\mathrm{pH}$ of 7.2 to 8.0, while brown sandstone treatments without bark mulch had a soil $\mathrm{pH}$ of 4.6 and 4.9. Electrical conductivity was significantly higher in treatments that received bark mulch. After three growing seasons at Birch River, average tree survival across all species was 
$69 \%$ and there were no tree survival differences between substrate, bark mulch, or hydroseeding. Average survival across all trees in all treatment combinations ranged from $41 \%$ for sycamore to $85 \%$ for sugar maple. Trees planted in brown sandstone had significantly greater volume of 313 $\mathrm{cm}^{3}$ compared to gray sandstone at $100 \mathrm{~cm}^{3}$. Black locust outperformed all other tree species with a volume of $806 \mathrm{~cm}^{3}$ with the next closest species being tulip poplar at $319 \mathrm{~cm}^{3}$.

In a separate study at Samples, four bulk density measurement techniques were used to determine bulk density in five substrates (four sandstone mine soils and one unmined native forest soil) and comparisons for accuracy and in-field efficiency were made among the four techniques. The techniques used were the frame apparatus, polyurethane foam, radiation, and sand-cone techniques. Bulk density measurements ranged from 1.35 to $1.76 \mathrm{~g} \mathrm{~cm}^{-3}$ for the four measurement techniques. Bulk density in the unmined native forest soil was significantly lower than the four sandstone substrates and no significant differences were found among the four sandstone substrates. The unmined native forest soil had a bulk density that was approximately 38 to $43 \%$ lower than the sandstone substrates. Bulk density ranged from 1.05 to $1.84 \mathrm{~g} \mathrm{~cm}^{-3}$ in the five substrates. The bulk density determined by the sand-cone technique was significantly lower than the other three determination techniques and no significant differences were found among the frame, polyurethane foam, and radiation techniques. The sand-cone technique produced a bulk density that was approximately 18 to $23 \%$ lower than the other techniques used. Significantly different in-field efficiency times were recorded for each of the four determination techniques. The radiation technique had the greatest in-field efficiency (345 s) while the frame had the lowest (1605 s) with the polyurethane foam and sand-cone techniques being intermediate between the two (612 and $837 \mathrm{~s})$. 


\section{ACKNOWLEDGMENTS}

I would like to extend a very heartfelt thank you to my committee members of Dr. Jeff Skousen, Dr. Eugenia Pena-Yewtukhiw, and Dr. Kate Piatek. I will forever be grateful to Dr. Skousen for providing me the opportunity to continue my education and taking a chance on me to embark into the field of mine reclamation. I'd like to thank Joan Wright for instruction on instruments in the lab and for analyzing numerous samples. Special thanks go to Mr. Travis Keene for countless hours spent in the field and on the road and for being a great sounding board in the office. I would like to thank Keith O’Dell and the employees from ICG Eastern, LLC and Gina Bays, Mitch Kalos, and the employees from Catenary Coal for their support with my study sites and ensuring my safety while on the mines. I'd like to thank my fellow graduate students and the friends that I've been lucky enough to meet in Morgantown. I want to thank them for putting up with me during stressful times and for always encouraging me to stay on the ball. Last but not least I want to thank my family for supporting my decision to go to graduate school and for encouraging me to follow my dreams. 


\section{TABLE OF CONTENTS}

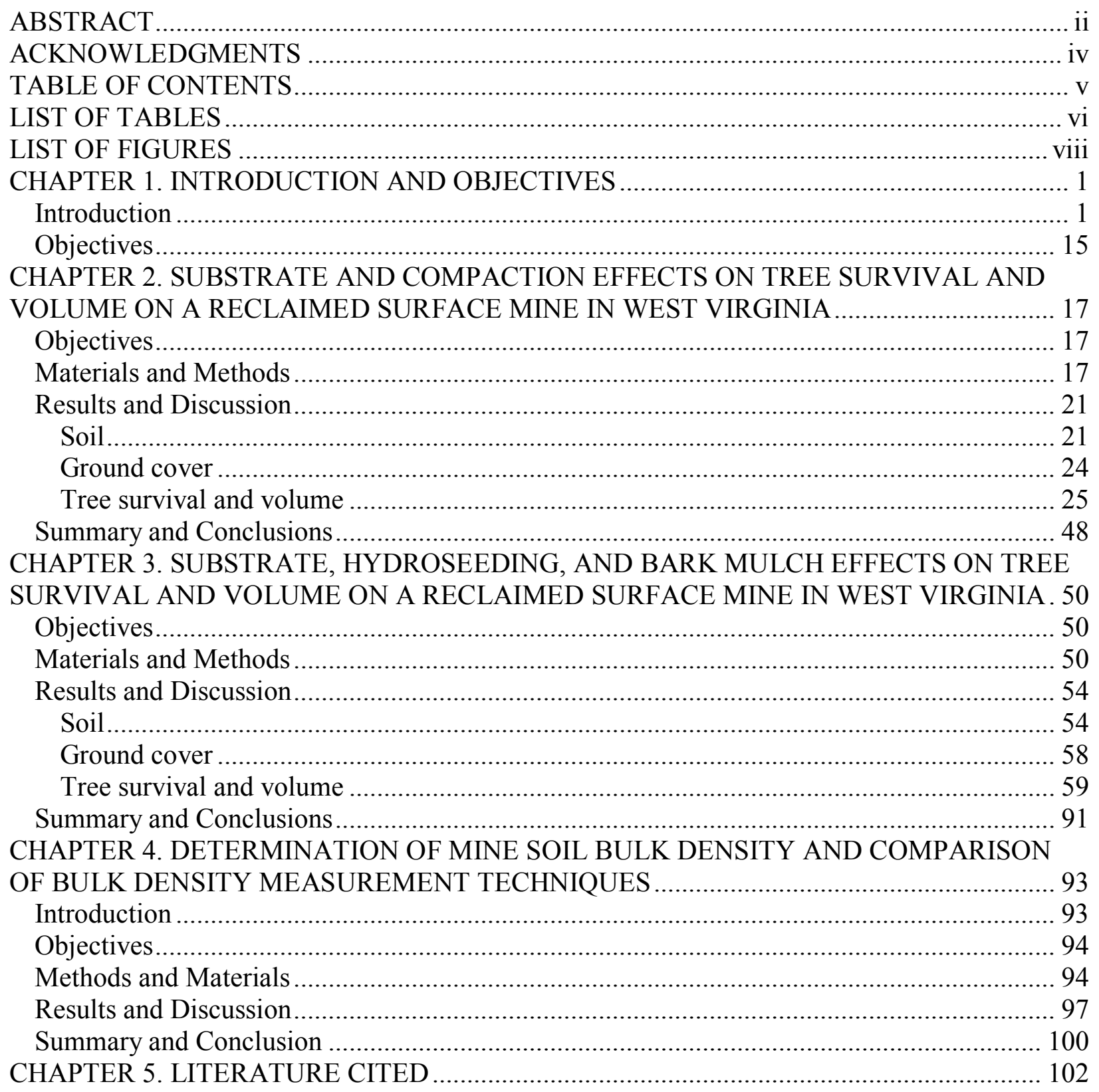




\section{LIST OF TABLES}

Table 2-1. Soil treatment combinations at Catenary Coal's Samples mine operation in Mine in Kanawha County, West Virginia

Table 2-2. Species and number of trees planted at Catenary Coal's Samples mine operation in Kanawha County, West Virginia. .18

Table 2-3. Species and rate of ground cover hydroseeded at Catenary Coal's Samples mine operation in Kanawha County, West Virginia. .18

Table 2-4. Vigor rating criteria used at Catenary Coal's Samples mine operation in Kanawha County, West Virginia.

Table 2-5. 2005 and 2009 soil properties in six soil treatments at Catenary Coal's Samples mine in Kanawha County, WV. .22

Table 2-6. 2005 and 2009 Elemental concentrations in six soil treatments at Catenary Coal's Samples mine in Kanawha County, WV. 24

Table 2-7. 2009 ground cover on six soil treatments at Catenary Coal's Samples mine in Kanawha County, WV. .25

Table 2-8. Number of trees sampled after five growing season in six soil treatments at Catenary Coal's Samples mine in Kanawha County, WV. .26

Table 2-9 Treatment effects for volume and survival after five growing season in six soil treatments at Catenary Coal's Samples mine in Kanawha County, WV....

Table 2-10. Survival of tree species after five growing season in six soil treatments at Catenary Coal's Samples mine in Kanawha County, WV.... .28

Table 2-11. Volume of tree species after five growing season in six soil treatments at Catenary Coal's Samples mine in Kanawha County, WV.... 28

Table 2-12. Vigor of tree species after five growing season in six soil treatments at Catenary Coal's Samples mine in Kanawha County, WV...

Table 3-1. Soil treatment combinations at ICG Eastern, LLC's Birch River Operation in Webster County, WV... 50

Table 3-2. Species and number of trees planted at ICG Eastern, LLC's Birch River Operation in Webster County, WV. .51

Table 3-3. Species and rate of ground cover hydroseeded at ICG Eastern, LLC's Birch River Operation in Webster County, WV... 
Table 3-4. Area and transect coverage soil treatment combinations at ICG Eastern, LLC's Birch River Operation in Webster County, WV

Table 3-5. Vigor rating criteria used at ICG Eastern, LLC's Birch River Operation in Webster County, WV.

Table 3-6. 2007-2009 soil properties in eight soil treatment combinations at ICG Eastern, LLC's Birch River Operation in Webster County, WV... .56

Table 3-7. 2007-2009 Elemental concentrations in eight soil treatment combinations at ICG Eastern, LLC's Birch River Operation in Webster County, WV

Table 3-8. 2009 Ground cover on eight soil treatment combinations at ICG Eastern, LLC's Birch River Operation in Webster County, WV

Table 3-9 Number of trees sampled after three growing seasons in eight soil treatment combinations at ICG Eastern, LLC's Birch River Operation in Webster County, WV..... 60

Table 3-10 Main treatment effects (substrate, bark, hydro) and species survival and volume after three growing seasons in eight soil treatment combinations at ICG Eastern, LLC's Birch River Operation in Webster County, WV. 61

Table 3-11 Survival of eleven species of trees after three growing seasons in eight soil treatment combinations at ICG Eastern, LLC's Birch River Operation in Webster County, WV....

Table 3-12 Volume of eleven species of trees after three growing seasons in eight soil treatment combinations at ICG Eastern, LLC's Birch River Operation in Webster County, WV ......63

Table 3-13 Vigor of eleven species of trees after three growing seasons in eight soil treatment combinations at ICG Eastern, LLC's Birch River Operation in Webster County, WV.... 63

Table 4-1. Substrates used for bulk density determination at Catenary Coal's Samples mine operation in Mine in Kanawha County, West Virginia.

Table 4-2. Soil bulk density and in-field efficiency for four soil bulk density determination techniques in five substrates at Catenary Coal's Samples mine operation in Kanawha County, West Virginia. 


\section{LIST OF FIGURES}

Figure 2-1a. Average survival of black cherry for three growing seasons in six soil treatments at Catenary Coal's Samples mine in Kanawha County, WV 30

Figure 2-1b. Average height of black cherry for five growing seasons in six soil treatments at Catenary Coal's Samples mine in Kanawha County, WV 30

Figure 2-1c. Average diameter of black cherry for five growing seasons in six soil treatments at Catenary Coal's Samples mine in Kanawha County, WV. 31

Figure 2-1d. Average volume of black cherry for five growing seasons in six soil treatments at Catenary Coal's Samples mine in Kanawha County, WV....

Figure 2-2a. Average survival of black locust for three growing seasons in six soil treatments at Catenary Coal's Samples mine in Kanawha County, WV. 32

Figure 2-2b. Average height of black locust for five growing seasons in six soil treatments at Catenary Coal's Samples mine in Kanawha County, WV. 32

Figure 2-2c. Average diameter of black locust for five growing seasons in six soil treatments at Catenary Coal's Samples mine in Kanawha County, WV

Figure 2-2d. Average volume of black locust for five growing seasons in six soil treatments at Catenary Coal's Samples mine in Kanawha County, WV .33

Figure 2-3a. Average survival of dogwood for three growing seasons in six soil treatments at Catenary Coal's Samples mine in Kanawha County, WV.... 34

Figure 2-3b. Average height of dogwood for five growing seasons in six soil treatments at Catenary Coal's Samples mine in Kanawha County, WV 34

Figure 2-3c. Average diameter of dogwood for five growing seasons in six soil treatments at Catenary Coal's Samples mine in Kanawha County, WV 35

Figure 2-3d. Average volume of dogwood for five growing seasons in six soil treatments at Catenary Coal's Samples mine in Kanawha County, WV 35

Figure 2-4a. Average survival of oak for three growing seasons in six soil treatments at Catenary Coal's Samples mine in Kanawha County, WV .36

Figure 2-4b. Average height of oak for five growing seasons in six soil treatments at Catenary Coal's Samples mine in Kanawha County, WV. 36

Figure 2-4c. Average diameter of oak for five growing seasons in six soil treatments at Catenary Coal's Samples mine in Kanawha County, WV... 
Figure 2-4d. Average volume of oak for five growing seasons in six soil treatments at Catenary Coal's Samples mine in Kanawha County, WV... 37

Figure 2-5a. Average survival of redbud for three growing seasons in six soil treatments at Catenary Coal's Samples mine in Kanawha County, WV. 38

Figure 2-5b. Average height of redbud for five growing seasons in six soil treatments at Catenary Coal's Samples mine in Kanawha County, WV. 38

Figure 2-5c. Average diameter of redbud for five growing seasons in six soil treatments at Catenary Coal's Samples mine in Kanawha County, WV.

Figure 2-5d. Average volume of redbud for five growing seasons in six soil treatments at Catenary Coal's Samples mine in Kanawha County, WV.

Figure 2-6a. Average survival of sugar maple for three growing seasons in six soil treatments at Catenary Coal's Samples mine in Kanawha County, WV. .40

Figure 2-6b. Average height of sugar maple for five growing seasons in six soil treatments at Catenary Coal's Samples mine in Kanawha County, WV

Figure 2-6c. Average diameter of sugar maple for five growing seasons in six soil treatments at Catenary Coal's Samples mine in Kanawha County, WV.

Figure 2-6d. Average volume of sugar maple for five growing seasons in six soil treatments at Catenary Coal's Samples mine in Kanawha County, WV. 41

Figure 2-7a. Average survival of tulip poplar for three growing seasons in six soil treatments at Catenary Coal's Samples mine in Kanawha County, WV.

Figure 2-7b. Average height of tulip poplar for five growing seasons in six soil treatments at Catenary Coal's Samples mine in Kanawha County, WV

Figure 2-7c. Average diameter of tulip poplar for five growing seasons in six soil treatments at Catenary Coal's Samples mine in Kanawha County, WV.... .43

Figure 2-7d. Average volume of tulip poplar for five growing seasons in six soil treatments at Catenary Coal's Samples mine in Kanawha County, WV.

Figure 2-8a. Average survival of white ash for three growing seasons in six soil treatments at Catenary Coal's Samples mine in Kanawha County, WV. .44

Figure 2-8b. Average height of white ash for five growing seasons in six soil treatments at Catenary Coal's Samples mine in Kanawha County, WV 
Figure 2-8c. Average diameter of white ash for five growing seasons in six soil treatments at Catenary Coal's Samples mine in Kanawha County, WV .45

Figure 2-8d. Average volume of white ash for five growing seasons in six soil treatments at Catenary Coal's Samples mine in Kanawha County, WV.

Figure 2-9a. Average survival of white pine for three growing seasons in six soil treatments at Catenary Coal's Samples mine in Kanawha County, WV.... .46

Figure 2-9b. Average height of white pine for five growing seasons in six soil treatments at Catenary Coal's Samples mine in Kanawha County, WV

Figure 2-9c. Average diameter of white pine for five growing seasons in six soil treatments at Catenary Coal's Samples mine in Kanawha County, WV

Figure 2-9d. Average volume of white pine for five growing seasons in six soil treatments at Catenary Coal's Samples mine in Kanawha County, WV. .48

Figure 3-1a. Average survival of black cherry for two growing seasons in eight soil treatment combinations at ICG Eastern, LLC's Birch River Operation in Webster County, WV....

Figure 3-1b. Average height of black cherry for three growing seasons in eight soil treatment combinations at ICG Eastern, LLC's Birch River Operation in Webster County, WV....

Figure 3-1c. Average diameter of black cherry for three growing seasons in eight soil treatment combinations at ICG Eastern, LLC's Birch River Operation in Webster County, WV.... .65

Figure 3-1d. Average volume of black cherry for three growing seasons in eight soil treatment combinations at ICG Eastern, LLC's Birch River Operation in Webster County, WV .......66

Figure 3-2a. Average survival of black locust for two growing seasons in eight soil treatment combinations at ICG Eastern, LLC's Birch River Operation in Webster County, WV .......67

Figure 3-2b. Average height of black locust for three growing seasons in eight soil treatment combinations at ICG Eastern, LLC's Birch River Operation in Webster County, WV .......67

Figure 3-2c. Average diameter of black locust for three growing seasons in eight soil treatment combinations at ICG Eastern, LLC's Birch River Operation in Webster County, WV....

Figure 3-2d. Average volume of black locust for three growing seasons in eight soil treatment combinations at ICG Eastern, LLC's Birch River Operation in Webster County, WV .......68

Figure 3-3a. Average survival of dogwood for two growing seasons in eight soil treatment combinations at ICG Eastern, LLC's Birch River Operation in Webster County, WV.... 
Figure 3-3b. Average height of dogwood for three growing seasons in eight soil treatment combinations at ICG Eastern, LLC's Birch River Operation in Webster County, WV .........70

Figure 3-3c. Average diameter of dogwood for three growing seasons in eight soil treatment combinations at ICG Eastern, LLC's Birch River Operation in Webster County, WV ........70

Figure 3-3d. Average volume of dogwood for three growing seasons in eight soil treatment combinations at ICG Eastern, LLC's Birch River Operation in Webster County, WV ........71

Figure 3-4a. Average survival of redbud for two growing seasons in eight soil treatment combinations at ICG Eastern, LLC's Birch River Operation in Webster County, WV .......72

Figure 3-4b. Average height of redbud for three growing seasons in eight soil treatment combinations at ICG Eastern, LLC's Birch River Operation in Webster County, WV ........72

Figure 3-4c. Average diameter of redbud for three growing seasons in eight soil treatment combinations at ICG Eastern, LLC's Birch River Operation in Webster County, WV ........73

Figure 3-4d. Average volume of redbud for three growing seasons in eight soil treatment combinations at ICG Eastern, LLC's Birch River Operation in Webster County, WV ........73

Figure 3-5a. Average survival of red oak for two growing seasons in eight soil treatment combinations at ICG Eastern, LLC's Birch River Operation in Webster County, WV .......74

Figure 3-5b. Average height of red oak for three growing seasons in eight soil treatment combinations at ICG Eastern, LLC's Birch River Operation in Webster County, WV ........75

Figure 3-5c. Average diameter of red oak for three growing seasons in eight soil treatment combinations at ICG Eastern, LLC's Birch River Operation in Webster County, WV ........75

Figure 3-5d. Average volume of red oak for three growing seasons in eight soil treatment combinations at ICG Eastern, LLC's Birch River Operation in Webster County, WV ........76

Figure 3-6a. Average survival of sugar maple for two growing seasons in eight soil treatment combinations at ICG Eastern, LLC's Birch River Operation in Webster County, WV .......77

Figure 3-6b. Average height of sugar maple for three growing seasons in eight soil treatment combinations at ICG Eastern, LLC's Birch River Operation in Webster County, WV ........77

Figure 3-6c. Average diameter of sugar maple for three growing seasons in eight soil treatment combinations at ICG Eastern, LLC's Birch River Operation in Webster County, WV ........78

Figure 3-6d. Average volume of sugar maple for three growing seasons in eight soil treatment combinations at ICG Eastern, LLC's Birch River Operation in Webster County, WV ........78 
Figure 3-7a. Average survival of sycamore for two growing seasons in eight soil treatment combinations at ICG Eastern, LLC's Birch River Operation in Webster County, WV......79

Figure 3-7b. Average height of sycamore for three growing seasons in eight soil treatment combinations at ICG Eastern, LLC's Birch River Operation in Webster County, WV .......80

Figure 3-7c. Average diameter of sycamore for three growing seasons in eight soil treatment combinations at ICG Eastern, LLC's Birch River Operation in Webster County, WV .......80

Figure 3-7d. Average volume of sycamore for three growing seasons in eight soil treatment combinations at ICG Eastern, LLC's Birch River Operation in Webster County, WV.......81

Figure 3-8a. Average survival of tulip poplar for two growing seasons in eight soil treatment combinations at ICG Eastern, LLC's Birch River Operation in Webster County, WV ......82

Figure 3-8b. Average height of tulip poplar for three growing seasons in eight soil treatment combinations at ICG Eastern, LLC's Birch River Operation in Webster County, WV .......82

Figure 3-8c. Average diameter of tulip poplar for three growing seasons in eight soil treatment combinations at ICG Eastern, LLC's Birch River Operation in Webster County, WV .......83

Figure 3-8d. Average volume of tulip poplar for three growing seasons in eight soil treatment combinations at ICG Eastern, LLC's Birch River Operation in Webster County, WV .......83

Figure 3-9a. Average survival of white ash for two growing seasons in eight soil treatment combinations at ICG Eastern, LLC's Birch River Operation in Webster County, WV .......84

Figure 3-9b. Average height of white ash for three growing seasons in eight soil treatment combinations at ICG Eastern, LLC's Birch River Operation in Webster County, WV .......85

Figure 3-9c. Average diameter of white ash for three growing seasons in eight soil treatment combinations at ICG Eastern, LLC's Birch River Operation in Webster County, WV .......85

Figure 3-9d. Average volume of white ash for three growing seasons in eight soil treatment combinations at ICG Eastern, LLC's Birch River Operation in Webster County, WV .......86

Figure 3-10a. Average survival of white oak for two growing seasons in eight soil treatment combinations at ICG Eastern, LLC's Birch River Operation in Webster County, WV ......87

Figure 3-10b. Average height of white oak for three growing seasons in eight soil treatment combinations at ICG Eastern, LLC's Birch River Operation in Webster County, WV .......87

Figure 3-10c. Average diameter of white oak for three growing seasons in eight soil treatment combinations at ICG Eastern, LLC's Birch River Operation in Webster County, WV .......88 
Figure 3-10d. Average volume of white oak for three growing seasons in eight soil treatment combinations at ICG Eastern, LLC's Birch River Operation in Webster County, WV .........88

Figure 3-11a. Average survival of white pine for two growing seasons in eight soil treatment combinations at ICG Eastern, LLC's Birch River Operation in Webster County, WV....

Figure 3-11b. Average height of white pine for three growing seasons in eight soil treatment combinations at ICG Eastern, LLC's Birch River Operation in Webster County, WV ........90

Figure 3-11c. Average diameter of white pine for three growing seasons in eight soil treatment combinations at ICG Eastern, LLC's Birch River Operation in Webster County, WV ........90

Figure 3-11d. Average volume of white pine for three growing seasons in eight soil treatment combinations at ICG Eastern, LLC's Birch River Operation in Webster County, WV ........91 


\section{CHAPTER 1. INTRODUCTION AND OBJECTIVES}

\section{$\underline{\text { Introduction }}$}

Two important industries in West Virginia are timber harvesting and coal mining. Both play vital roles in the economy, employment, and social and cultural history of the state. West Virginia is the third most forested state in the U.S., which allows timber harvesting and the production of wood products throughout much of the state. Forest related-industries employ over 30,000 individuals and contribute $\$ 3.2$ billion dollars annually into the state economy (West Virginia Forestry Association, 2008). Mining for coal has been practiced commercially in West Virginia since the first commercial mine was established in 1834 (West Virginia Office of Miners' Health Safety and Training, 2010). In 2009, 144 million tons of coal were mined, and the coal industry employed over 30,000 workers through mining and supporting industries, with \$3.5 billion dollars contributed to the state economy (West Virginia Office of Miners' Health, Safety and Training, 2010). Together coal mining and timber harvesting contribute substantially to the economic stability of the state by providing a combined $\$ 6.7$ billion dollars to West Virginia's gross state product. This means that mining, forestry, and their supporting industries contributed an estimated $11 \%$ of West Virginia's 2008 gross state product of $\$ 61.6$ billion dollars (Bureau of Economical Analysis, 2009). This reveals the importance of the two industries in the West Virginia economy.

Coal mining has disturbed approximately 2.4 million hectares (6 million acres) since 1930 in the United States (Skousen et al., 2006). Early surface mining disturbed large areas of land but left it in a condition that was favorable for natural invasion and reestablishment of forest species. This was because no laws existed for compaction of the surface or for seeding herbaceous species to cover the ground. Therefore, the resulting mine soils were deep, nontoxic, 
loose and porous (noncompacted), and void of dense herbaceous competition (Torbert and Burger, 2000). This began to change as regulations in the 1940's started to call for the reclamation of mined lands. From the 1940's to 1977, regulations evolved into requiring more grading of the surface to create smooth landscapes and the seeding of ground cover to control erosion. A federal mining law titled the Surface Mining Control and Reclamation Act (SMCRA, 1977) was eventually passed in 1977.

SMCRA regulations require coal operators to reclaim land in a timely manner to conditions that are capable of supporting the same uses or higher and better uses than were supported before any mining occurred (Sect. 816.133). SMCRA states that coal operators must establish a vegetative cover that is diverse, effective, and permanent, and capable of stabilizing the soil surface from erosion (Sect. 816.111). The interpretation of SMCRA by mine regulators and operators led to pasture and hayland being the dominant types of post mining land use and reclamation practices were developed to optimize forage production. However, in many areas of Appalachia, reclaimed surface mines are remote and these pastures and haylands go unmanaged and provide little economic benefit to the land owner (Torbert and Burger, 2000).

Starting in the late 1990's, operators at the insistence of landowners began to restore forest on lands that were disturbed by mining (Torbert and Burger, 2000). However, current reclamation practices and interpretations by regulators made reforestation on mined lands difficult due to heavy soil compaction and the seeding of aggressive herbaceous ground covers. With this knowledge in mind, the Appalachian Regional Reforestation Initiative (ARRI) was formed to encourage and support the restoration of high quality forests on reclaimed coal mines in the eastern United States (Angel et al., 2005). ARRI emphasized the Forestry Reclamation Approach (FRA), which is a method for reclaiming coal-mined land under SMCRA to forest and 
is based on knowledge gained from both scientific research and experience (Angel et al., 2005). The FRA consists of five steps and is achieved by:

1) creating a suitable rooting medium for good tree growth that is no less than $1.2 \mathrm{~m}$ deep and comprised of topsoil, weathered sandstone, and/or the best available material; 2) loosely grading the topsoil or topsoil substitutes to create a non-compacted growth medium;

3) using ground covers that are compatible with growing trees;

4) planting two types of trees (early succession species for wildlife and soil stability and commercially valuable crop trees) and;

5) using proper tree planting techniques (Burger et al., 2005a).

Utilizing the five steps of the FRA can lead to successful establishment and growth of trees on reclaimed surface mines.

Surface mining in West Virginia is regulated by the West Virginia Surface Mining Reclamation Rule (WVDEP, 2002). Under this rule, two types of post mining land use, Commercial Forestry and Forestry, focus on restoring forests after mining. Commercial Forestry and Forestry post mining land uses are defined in subsection 2.31 of the West Virginia Surface Mining Reclamation Rule. In subsection 2.31.a., Commercial Forestry is defined as a long-term post mining land use designed to:

1) achieve greater forest productivity than that found on the mine site before mining;

2) minimize erosion and/or sediment yield and serve the hydrologic functions of infiltrating, holding, and yielding water commonly found in undisturbed forests;

3) result in biodiversity by facilitating rapid recruitment of native species of plants and animals via the process of natural succession; 
4) result in a premium forest that will thrive under stressful conditions and;

5) result in landscape, vegetation and water resources that create habitat for forestdwelling wildlife.

In subsection 2.31.b., Forestry is defined as a long-term post mining land use for the production of wood or wood products designed to:

1) achieve forest productivity equal to that found on the mine site before mining;

2) minimize erosion and/or sediment yield and serve the hydrologic functions of infiltrating, holding, and yielding water commonly found in undisturbed forests;

3) result in biodiversity by facilitating rapid recruitment of native species of plants and animals via the process of natural succession and;

4) result in landscape, vegetation and water resources that create habitat for forest dwelling wildlife.

In order to achieve the intended outcome of Commercial Forestry and Forestry postmining land uses, certain steps for each must be followed. For Commercial Forestry, the final surface material used as the planting and growth medium shall consist of a minimum of 1.2 $\mathrm{m}$, and an average of at least $1.5 \mathrm{~m}$, of soil or a mixture of materials consisting of no less than one-third soil and two-thirds selected overburden materials or soil substitutes, and for forestry areas, the final surface material used as the planting and growth medium shall consist of a minimum of $1.2 \mathrm{~m}$, or a mixture of soil and suitable soil substitutes (Section 7.4.b.1.D.8-9.) due to the limited depth of topsoil that is present before mining (WVDEP, 2002). This often means coal operators must use a soil substitute consisting of weathered brown sandstone which comes from within 5 to $10 \mathrm{~m}$ of the soil surface. The weathered brown sandstone must be removed from the surface at the beginning of the mining process and stock piled on the mine site out of the way 
of production. This equals added handling and labor costs that must be incurred by the coal operator. As a result, operators have preferred using the bottom most overburden layer (the material just above the lowest extracted coal seam) usually consisting of unweathered gray sandstone as the soil substitute.

There are a variety of overburden materials available when reclaiming surface mined land and the choice of material used for mine reclamation can often dictate the performance of the chosen post mining land use. SMCRA states that operators must demonstrate that the soil medium used is equal to or better than premining soil for sustaining vegetation, and is the best available material to support vegetation (Sect. 816.22 in SMCRA). Sandstone, siltstone, and shale are commonly present in overburdens on mined lands in West Virginia and are used as topsoil substitutes. Torbert et al. (1990) conducted a greenhouse study with sandstone, siltstone, and mixtures of both and found that pines planted in sandstone had five times greater volume than those planted in siltstone. They also found as siltstone proportion increased in the substrate, the growth of trees decreased. Similar results were also found by Casselman et al. (2006) in a field study across Virginia, West Virginia, and Ohio in which survival and growth were better on sites derived from sandstone as opposed to siltstone and shale. In West Virginia, there are two types of sandstone most commonly available for reclamation purposes, weathered brown sandstone and unweathered gray sandstone. In many research studies, weathered brown sandstone was shown to produce trees with significantly greater growth than unweathered gray sandstone (Emerson et al., 2009; Showalter et al., 2010). In an attempt to benefit from the availability of the unweathered gray sandstone and the favorable properties for growth found in the weathered brown sandstone, researchers have conducted studies by mixing the two substrates together. Angel et al. (2008) found that the survival of white oak, red oak, tulip poplar, and green 
ash were significantly lower in mixed sandstone than brown sandstone but found that the trees had significantly greater height and volume in weathered brown sandstone followed by the mixture and then unweathered gray sandstone. Opposite results for survival were found for American chestnut trees in which the highest survival (100\%) was found in a mixture of weathered and unweathered sandstones (French et al., 2007).

The physical and chemical properties of the final planting substrate depend on the overburden material that is left at the surface after reclamation and those properties can vary widely across materials. Some commonly analyzed physical properties and the ranges that can be found in mine soils include: rock fragment content from 2 to $88 \%, \mathrm{pH}$ from 3.2 to 8.5 , electrical conductivity from 0.02 to $4.72 \mathrm{dS} \mathrm{m}^{-1}$, bulk density from 0.61 to $1.94 \mathrm{~g} \mathrm{~cm}^{-3}$, (Andrews et al., 1998; Emerson et al., 2009; Showalter et al., 2007). In addition, some commonly analyzed chemical properties and the ranges that can be found in mine soils include: elemental concentrations for P from 0.92 to $34.86 \mathrm{mg} \mathrm{kg}^{-1}, \mathrm{~K}$ from 2 to $161 \mathrm{mg} \mathrm{kg}^{-1}, \mathrm{Ca}$ from 5 to $1426 \mathrm{mg}$ $\mathrm{kg}^{-1}$, Mn from 1.5 to $57.7 \mathrm{mg} \mathrm{kg}^{-1}$, and Fe from 0.05 to $138.9 \mathrm{mg} \mathrm{kg}^{-1}$ (Andrews et al., 1998; Emerson et al., 2009; Showalter et al., 2007). These parameters are important in many aspects of establishing and growing trees on surface mined lands. Many of these factors can change rapidly after reclamation as the overburden material weathers over time and soil formation begins. The chemical properties of the materials can become equal to or better than native unmined soils (Bussler et al., 1984; Haering et al., 1993; Haering et al., 2004).

The weathered brown sandstone and unweathered gray sandstone overburden materials commonly used in reclamation of surface mines in West Virginia have some distinctly different characteristics. Weathered brown sandstone is often more acidic with a $\mathrm{pH}$ of 4.3 to 6.5 while unweathered gray sandstone typically has a pH of 7.6 to 8.5 (Angel et al., 2008; Emerson et al., 
2009). This is important when looking at past research and the $\mathrm{pH}$ requirements of species found on mine sites and could be a predictive factor as to the species that will most likely colonize the site. Skousen et al. (2006) found that nonreclaimed mine sites with soil $\mathrm{pH}<5$ were most commonly dominated by trees, while sites with $\mathrm{pH}>5$ were dominated by herbaceous plants. This shows the importance of choosing a material with a $\mathrm{pH}$ that would be more favorable to trees to limit competition by herbaceous plants.

Percent rock fragments are also a parameter that is often different between brown and gray sandstone materials. Weathered brown sandstone has been shown to have rock fragment contents of 36 to $63 \%$ while unweathered gray sandstone if higher at 60 to $71 \%$ (Emerson et al., 2009). High rock fragment contents can produce mixed results on tree growth depending on the texture of the surrounding soil. High rock fragment contents in fine textured soils can increase the penetration of air and water to plant roots, but in coarse textured soils high rock fragment contents can result in a lower water holding and exchange capacity (Fisher and Binkley, 2000). Rodrigue and Burger (2004) found that the relationship of rock fragment content and water holding capacity to be the second and third most important factors in the productivity of mined lands planted with trees.

An additional parameter found to be important when discussing the productivity of these materials for trees is electrical conductivity (EC) (Andrews et al., 1998; Rodrigue and Burger, 2004). Electrical conductivity is used as a measure of the concentration of soluble salts found in the substrate material. Some research shows that EC is significantly different between weathered brown sandstone and unweathered gray sandstone; however, this varies greatly across studies. Electrical conductivity is important to the growth of trees though and levels of $2 \mathrm{dS} \mathrm{m}^{-1}$ are thought to be marginally detrimental and levels of $3 \mathrm{dS} \mathrm{m}^{-1}$ are considered toxic for plants on 
mined lands (Cummins et al., 1965).

After the passage of the Surface Mining Control and Reclamation Act of 1977, the majority of surface mined land in WV was reclaimed to pasture and hayland. For this type of reclamation, the land is often reclaimed by heavily compacting soils for stabilization, to minimize erosion, and to provide a good seed bed for pasture and hayland seeds. This heavy compaction has been referenced to be the most limiting factor in reclamation using trees on post SMCRA reclaimed lands (Larson and Vimmerstedt, 1983). Heavy soil compaction affects the tress mainly by impacting root growth. Compacted soils can lead to an increase in the soil resistance to penetration, poor aeration, slow movement of nutrients and water, and the buildup of toxic gases around the roots (Brady and Weil, 2002). Soil compaction can be limited if the soil is replaced by end-dumping the soil and minimizing travel of equipment over the soil surface at the start of reclamation (Sweigard et al., 2007a). Research has shown that by end-dumping the overburden material and minimizing grading, tree survival and growth is significantly better when compared to compacted sites (Angel et al., 2006; Michels et al., 2007; Torbert and Burger, 1990; Zeleznik and Skousen, 1996).

Another important aspect of reclamation with trees is the amount and type of ground cover on the site. State and federal regulations require coal operators to establish a vegetative cover that is diverse, effective, and permanent, and capable of stabilizing the soil surface from erosion (Sect. 816.111). Torbert and Burger (2000) state the use of dense herbaceous ground cover as being one of the main hindrances of tree establishment on mined lands. This effect of herbaceous ground cover on tree performance on surface mined lands has been extensively researched. Research has demonstrated that survival, height, and/or volume of trees show significant increases as competing vegetation is decreased through chemical control or by not 
being present (Ashby, 1997; Burger et al., 2005b; Burger et al., 2008; Chaney et al., 1995; Fields-Johnson et al., 2008; King and Skousen, 2003; Rizza et al., 2007; Skousen et al., 2006; Torbert et al., 1985; Torbert et al., 2000). Aggressive herbaceous ground cover such as K-31 tall fescue (Festuca arundinacea L.), red clover (Trifolium pratense L.), and sericea lespedeza (Lespedeza cuneata L.) impact trees by interfering with tree establishment, and by competing for light, nutrients, and water as well as providing cover for rodents that can girdle and kill young trees, or by attracting wildlife which can browse the trees (Torbert and Burger, 2000). The primary way to minimize these interactions from occurring is to plant tree compatible ground covers (Burger and Zipper, 2002; Burger et al., 2009; Skousen and Zipper, 2009). Species like birdsfoot trefoil (Lotus corniculatus L.), ladino clover (Trifolium repens L.), red top (Agrostis gigantean L.), and perennial ryegrass (Lolium perenne L.) can be planted during initial reclamation and are less competitive but will still provide cover that meets regulations. Aside from the substrate present or the ground cover used, the suitability and productivity of mine soils for trees can be influenced with the addition of soil amendments.

Aside from the substrate material and ground cover used for reclamation, the suitability and productivity of mine soils for trees can be influenced with the addition of soil amendments. Bark mulch, or wood waste, is an organic mulch that can often be acquired from sawmills and timbering operations and used on mined land as an amendment (Falk, 1997; Norland, 2000). Research has shown that the surface application of bark mulch significantly increases the survival and height of trees planted in mine soils (Angel et al., 2006; Ringe, 1988; Ringe et al., 1989). Schoenholtz et al. (1992) found that incorporating wood chips into the mine soil also showed a significant increase in tree growth. The addition of bark mulch has also been shown to be effective in the control of erosion when applied to the soil surface at depths $>2 \mathrm{~cm}$, which can 
decrease the need for vegetative cover for erosion control (Demars et al., 2000). Bark mulch increases suitability and productivity of mine soils for trees but it does not significantly alter mine soil physical properties such as bulk density, maximum penetration depth, penetration resistance, and total pore space (Conrad et al., 2008; Plass, 1982). Overall, bark mulch can be used to (i) prevent the loss of water from evaporation, increase water-holding capacity of the soil, and increase surface wetness; (ii) aid in soil stabilization by reducing surface erosion; (iii) increase soil organic matter; (iv) reduce soil surface temperature extremes; (v) decrease surface crust formation; (vi) increase structural stability and permeability of soil; and (vii) reduce germination and growth of weeds (Norland, 2000). In addition to the substrate material, ground cover, and any amendments that are used during reclamation, certain species of trees must be included when reclaiming to Commercial Forestry or Forestry post mining land uses.

Section 7.4.b.1.H.1. of The West Virginia Surface Mining Reclamation Rule (WVDEP, 2002) outline the species requirements for Commercial Forestry and Forestry post mining land uses. Tree species selection shall be based on site-specific characteristics and long-term goals outlined in the forest management plan. For Commercial Forestry, all areas suitable for hardwoods must be planted with native hardwoods at a rate of 500 seedlings per acre in continuous mixtures across the permitted area with at least six species from the following list: white oak (Quercus alba L.), chestnut oak (Quercus prinus L.), northern red oak (Quercus rubra L.), black oak (Quercus velutina Lam.), white ash(Fraxinus americana L.), tulip poplar (Liriodendron tulipifera L.), basswood (Tilia americana L.), cucumber magnolia (Magnolia acuminata L.), black walnut (Juglans nigra L.), sugar maple (Acer saccharum Marsh.), black cherry (Prunus serotina Ehrh.), or native hickories (Carya spp.). For Forestry all areas suitable for hardwoods must be planted with native hardwoods at a rate of 450 seedlings per acre in 
continuous mixtures across the permitted area with at least three or four species from the following list white oak, chestnut oak, northern red oak, black oak, white ash, tulip poplar, basswood, cucumber magnolia, black walnut, sugar maple, black cherry, or native hickories. Each of these species and many other species used for reclamation have varying growth habits and site requirements that are needed to achieve optimum performance.

Black cherry is a valuable timber species in West Virginia and the Appalachian region and is most often used for furniture and interior finishing (Fralish and Franklin, 2002; Hough, 1936). It's considered a medium-sized tree that commonly attains heights of 12 to $30 \mathrm{~m}$ with a diameter up to $1.5 \mathrm{~m}$, depending on site quality and surrounding trees (Preston, 1989; Harlow, 1935a; Hough, 1936). Black cherry is a relatively shade intolerant species and grows rapidly through the seedling and pole stages, which generally leads to it overtopping surrounding species such as sugar maple or American beech (Fralish and Franklin, 2002; Marquis, 1990; Preston, 1989). It grows best on rich, moist sites but throughout its range it's found on sites that are strongly acid, relatively infertile, and have high coarse fragment content (Harlow, 1935a; Marquis, 1990).

Black locust (Robinia pseudoacacia L.) has been extensively planted on surfaced mined lands throughout Appalachia for erosion control, nitrogen fixation, and revegetation (Fralish and Franklin, 2002; Huntley, 1990). It's a medium-sized tree that commonly attains heights of 12 to $24 \mathrm{~m}$ with a diameter up to one meter (Core, 1959; Harlow 1953a). It's a shade intolerant species that grows best on rich, moist limestone soils (Huntley, 1990; Preston, 1989). In those rich, moist limestone soils, black locust can attain an increase in height of approximately one meter per year and an increase in diameter of $1.3 \mathrm{~cm}$ per year but the growth rate declines quickly after 20 to 30 years of age (Harlow, 1953a). However, black locust is capable of colonizing harsh sites with the 
exception of poorly drained, heavily compacted, and excessively dry sites (Hicks 1998; Huntley, 1990).

Dogwood (Cornus racemosa Lam.) is a species with some commercial value but it's chiefly planted on surface mines as a wildlife tree in which birds, squirrels, and other wildlife feed on its berries (Core, 1959). It's a small tree that commonly grows to heights of 5 to $13 \mathrm{~m}$ with a diameter of approximately 0.4 m (Core, 1959; Fralish and Franklin, 2002). It's considered a slow growing tree and is often found thriving in the shade of other trees (Core, 1959; Hough, 1936). It grows on deep moist soils along streams to well-drained upland soils but does not grow well on upper slopes and ridges (McLemore, 1990). Skousen et al. (2006) found that dogwood grows well on surface mined lands and will colonize as a volunteer. However, Skousen's (2006) study site was 22 years of age which could indicate that dogwood is more likely to move into an area and have success after a forest canopy is established and the site conditions are more favorable.

White oak, one of the most valuable American hardwoods, is common throughout West Virginia and is used in furniture, veneer, railroad ties, and many other products (Core, 1959; Harlow, 1935a). It's considered a large tree that attains heights of 18 to $30 \mathrm{~m}$ with a diameter up to $1.2 \mathrm{~m}$ (Core, 1959; Harlow, 1935a). White oak is an intermediately shade tolerate species that is slow growing and often found with other oaks, hickories, and tulip poplar (Hicks, 1998, Hough, 1936). It grows well on a variety of soils and does best on north or east slopes and coves and does poorly on dry, shallow ridges, poorly drained flats, and wet bottom lands (Rogers, 1990).

Red oak is another species of tree that is common in West Virginia and Appalachia and is highly valued for interior furnishings and for a wildlife tree that provides hard mast (Core, 1959; 
Hicks, 1998). It's considered a medium sized tree that commonly attains heights of 18 to $33 \mathrm{~m}$ with a diameter up to $1.2 \mathrm{~m}$ (Core, 1959; Fralish and Franklin, 2002; Preston, 1989). Red oak is a moderate to fast growing species that is moderately shade intolerant (Hicks, 1998; Preston, 1989). It grows in a variety of soil types from clay to loamy sands and soils with high rock fragment contents and can be found in coves, well-drained slopes, and rich uplands (Fralish and Franklin, 2002; Hough, 1936). It prefers deep, fertile, well drained soils on lower and middle slopes with northerly or easterly aspects (Harlow, 1935a; Sander, 1990).

Chestnut oak is a very common tree in the hilly sections of West Virginia and is often harvested and used for the same purposes as similar upland white oaks (Core, 1959). It's considered a large tree that commonly attains heights of $30 \mathrm{~m}$ with a diameter up to 1.0 to $1.3 \mathrm{~m}$ (Core, 1959; Fralish and Franklin, 2002). Chestnut oak is a slow growing species that is intermediately shade intolerant (Hicks, 1998; Preston, 1989). It grows in best on well-drained fertile bottomlands but it is usually found on poorer sites on exposed upper slopes and ridges (Harlow, 1935a).

Redbud (Cercis canadensis L.), much like dogwood, has little commercial value and is chiefly planted on surface mines as a wildlife tree and to add diversity to the types of trees planted (Core, 1959). It is often a shrubby species but can attain a height of 12 to $15 \mathrm{~m}$ with a diameter of $0.6 \mathrm{~m}$ (Hough, 1936; Preston, 1989). Redbud is a shade tolerant species and is often found in the understory amongst taller trees (Hough, 1936; Preston, 1989). It shows good growth on moist well-drained sites with $\mathrm{pH}$ of 7.5 and is common along drainages, coves, and hollows (Dickson, 1990; Fralish and Franklin, 2002).

Sugar maple is one of West Virginia's best known and valuable trees and is highly prized as a timber species for the production of flooring and furniture (Core, 1959; Preston, 1989). It is 
considered a large tree that commonly attains heights of 18 to $33 \mathrm{~m}$ with a common diameter of $0.9 \mathrm{~m}$ (Godman et al., 1990; Harlow, 1935a). Sugar maple is a shade tolerant species and due to often developing under a closed canopy is slow growing (Godman et al., 1990; Preston, 1989). It grows on a variety of soils from strongly acid $(\mathrm{pH} 3.7)$ to slightly alkaline $(\mathrm{pH} 7.3)$ and in sands, loamy sands, sandy loams, loams and silt loams (Godman, 1965). However, best growth is seen on moist, rich, well-drained loam or sandy soils (Harlow, 1935a; Hicks, 1998

Tulip poplar, one of the tallest eastern hardwoods, is found throughout West Virginia and is a highly valued timber species used for furniture, exterior and interior trim, and in some cases high value veneer (Beck, 1990; Core, 1959). It is a large tree that commonly attains heights of 24 to $58 \mathrm{~m}$ with a diameter of 1 to 2 meters and greater (Hough, 1936; Preston, 1989). Tulip poplar is a fast growing, very shade intolerant species that is often found as a mixture with other hardwood species (Preston, 1989). It grows on a variety of soil types, with the exception of very wet or very dry soils, and grows best, showing a preference for, cool, deep, moist sites (Hicks, 1998; Hough, 1936).

White ash is the most common ash found in West Virginia and most often harvest as a timber tree for use as tool handles, baseball bats, and furniture (Core, 1959; Hough, 1936). It is a medium sized tree and commonly attains heights of 15 to $25 \mathrm{~m}$ with a diameter of 0.6 to $1.2 \mathrm{~m}$ and under exception conditions can grow to $37 \mathrm{~m}$ with a diameter of $1.8 \mathrm{~m}$ (Core, 1959; Hough, 1936; Preston, 1989). White ash is an intermediately shade tolerant species that is fast growing but can take as long as 15 years to reach a height of $1.5 \mathrm{~m}$ while its root system is becoming established (Hicks, 1998; Preston, 1989; Schlesinger, 1990). Once its roots are established it can often out grow many of the surrounding trees. It grows best on deep, moist soils on north slopes and is found less commonly in sandy soils (Harlow, 1935a; Fralish and Franklin, 2002; 
Schlesinger, 1990). White ash has been found to have exceptional survival and growth on mine soils by Skousen et al. (2009) and performed as well in our study.

White pine (Pinus strobus L.), one of the largest eastern conifers, is distributed sporadically throughout West Virginia and is typically used for construction purposes, box boards, and many other products (Core, 1959; Harlow, 1935b). It's considered a large tree that commonly attains heights of 18 to $30 \mathrm{~m}$ with a diameter of 0.6 to 1.2 meter and exceptional specimens attain heights of 50 to $60 \mathrm{~m}$ with diameters of $1.5 \mathrm{~m}$ (Core, 1959; Fralish and Franklin, 2002; Hough, 1936). White pine is fast growing species that is relatively shade tolerant when young but becomes shade intolerant as it matures (Hicks, 1998; Preston, 1989). It grows across a variety of soils and generally grows well on moist, well drained sandy soils and does not grow well on clay soils where it is often out competed by hardwood trees (Harlow, 1935b; Wendel and Smith, 1990). White pine is particularly important in Commercial Forestry post mining land use as a measure of successful reclamation. In order to meet bond release requirements, it must attain increases in height increments equal to or greater than $0.46 \mathrm{~m}$ on average for four or more consecutive years. This study was initiated to determine the suitability of brown and gray sandstone substrate material for the survival and growth of trees used for Commercial Forestry and Forestry post mining land uses in West Virginia.

\section{Objectives}

Chapter 2: Samples Mine

a. Determine growth and survival of trees growing in weathered brown and unweathered gray sandstone substrates in compacted and noncompacted conditions.

b. Assess the physical and chemical properties of mine soils five years after reclamation.

Chapter 3: Birch River Mine 
a. Determine growth and survival of trees growing in weathered brown and unweathered gray sandstone substrates with and without treatments of herbaceous ground cover and bark mulch.

b. Assess the physical and chemical properties of mine soils three years after reclamation.

Chapter 4: Bulk Density at Samples

a. Determine soil bulk density in mine soils composed of weathered brown sandstone and unweathered gray sandstone and to compare these to unmined native forest.

b. Compare four soil bulk density measurement techniques and evaluate their in-fieldefficiency. 


\section{CHAPTER 2. SUBSTRATE AND COMPACTION EFFECTS ON TREE SURVIVAL AND VOLUME ON A RECLAIMED SURFACE MINE IN WEST VIRGINIA}

\section{$\underline{\text { Objectives }}$}

a. Determine tree growth and survival of weathered brown and unweathered gray sandstone substrates in compacted and noncompacted conditions.

b. Assess the physical and chemical properties of mine soils five years after reclamation.

\section{Materials and Methods}

This study was conducted at Catenary Coal's Samples mine $\left(38^{\circ} 26^{\prime} 27^{\prime \prime}\right.$ N, 80³6 $33^{\prime \prime}$ W) near the town of Eskdale, in Kanawha County, West Virginia. In January 2005, Catenary Coal constructed three demonstration plots totaling 8.5 hectares. Each plot was constructed by end-dumping either weathered brown or unweathered gray sandstone overburden material in closely adjacent piles. The three plots consisted of weathered brown sandstone with a depth of $1.5 \mathrm{~m}$, weathered brown sandstone with a depth of $1.2 \mathrm{~m}$, and unweathered gray sandstone with a depth of $1.5 \mathrm{~m}$. After placement, one half of each plot was compacted by using a bulldozer to completely cover the surface with tracks (requiring three to four passes). The other half of the plot was graded with only one or two passes of the bulldozer to minimize compaction. Overall there were six soil treatment combinations (Table 2-1).

Table 2-1. Soil treatment combinations at Catenary Coal's Samples mine operation in Mine in Kanawha County, West Virginia

\begin{tabular}{ll}
\hline Treatment & Abbreviation \\
\hline 1.2-m weathered brown sandstone compacted & $4 \mathrm{~B}-\mathrm{C}$ \\
1.2-m weathered brown sandstone noncompacted & $4 \mathrm{~B}-\mathrm{NC}$ \\
1.5-m weathered brown sandstone compacted & $5 \mathrm{~B}-\mathrm{C}$ \\
$1.5-\mathrm{m}$ weathered brown sandstone noncompacted & $5 \mathrm{~B}-\mathrm{NC}$ \\
$1.5-\mathrm{m}$ unweathered gray sandstone compacted & $5 \mathrm{G}-\mathrm{C}$ \\
$1.5-\mathrm{m}$ unweathered gray sandstone noncompacted & $5 \mathrm{G}-\mathrm{NC}$ \\
\hline
\end{tabular}

In March of 2005, after final grading, eleven species of trees were manually planted by a tree planting company in a random fashion across the 8.5 hectare demonstration plots (Table 2- 
2). The trees were planted on a 2.4 by $2.4 \mathrm{~m}$ spacing equaling an initial density of 1680 trees per hectare across the three plots. In fall 2007, the three demonstration plots were hydroseeded with a seed mixture at $15.4 \mathrm{~kg} / \mathrm{ha}$ (Table 2-3).

Table 2-2. Species and number of trees planted at Catenary Coal's Samples mine operation in Kanawha County, West Virginia

\begin{tabular}{lcc}
\hline Species & No. Planted & \% of trees planted \\
\hline Black cherry & 465 & 3 \\
Black locust & 465 & 3 \\
Chestnut oak & 1,250 & 8 \\
Eastern redbud & 465 & 3 \\
Gray dogwood & 465 & 3 \\
Northern red oak & 3,400 & 22 \\
Sugar maple & 1,500 & 10 \\
Tulip poplar & 1,250 & 8 \\
White ash & 2,500 & 16 \\
White oak & 2,500 & 16 \\
White pine & 1,250 & 8 \\
Total & 15,510 & 100 \\
\hline
\end{tabular}

Table 2-3. Species and rate of ground cover hydroseeded at Catenary Coal's Samples mine operation in Kanawha County, West Virginia

\begin{tabular}{lc}
\hline Species & Rate \\
\hline & $\mathrm{kg} \mathrm{ha}-1$ \\
Birdsfoot trefoil & 11.0 \\
Perennial ryegrass & 2.2 \\
Redtop & 2.2 \\
Total & 15.4 \\
\hline
\end{tabular}

All data collected (soil, cover, and trees) was taken from within two 2.7-m wide and 195$\mathrm{m}$ long permanent transects that were arranged in an $\mathrm{X}$ pattern across each treatment. During August of each year (2005-2009), trees located inside the transect were identified to species, measured for height to the highest point of live growth, and measured for diameter $2.5 \mathrm{~cm}$ above the soil surface. Volume for each tree was determined by $\mathrm{HD}^{2}$ where $\mathrm{H}=$ height and $\mathrm{D}=$ diameter.

A vigor rating was also assigned to each tree sampled during 2008 and 2009. Vigor was based on a visual assessment and ranged from 1 to 5 with 1 being trees with $>75 \%$ leaves 
discolored and extensive dieback present and 5 being trees with $<25 \%$ leaves discolored and no visible dieback (Table 2-4).

Table 2-4. Vigor rating criteria used at Catenary Coal's Samples mine operation in Kanawha County, West Virginia

\begin{tabular}{cll}
\hline Rating & Modifier & \multicolumn{1}{c}{ Vigor criteria } \\
\hline 1 & very poor & $>75 \%$ leaves discolored; extensive dieback \\
2 & poor & $50 \%-75 \%$ discoloration; dieback present \\
3 & moderate & $25-50 \%$ leaves discolored; dieback present \\
4 & good & $25-50 \%$ leaves discolored; no dieback present \\
5 & very good & $<25 \%$ leaf discolored; no dieback present \\
\hline
\end{tabular}

During August 2008 and 2009, herbaceous ground cover was determined using 1-m² quadrats. Twenty randomly placed quadrat locations were sampled within the transect boundaries for each soil treatment combination for a total of 120 measurements. Percent plant cover, percent litter cover, and rock/bare ground were estimated within each quadrat.

Soil samples were collected during July-August 2005-2009. Soil sampling locations were randomly selected inside the transect boundaries and five samples were taken from each soil treatment combination for a total of 30 samples each year. Soil samples were collected from the top $15 \mathrm{~cm}$ with a trowel, placed in labeled bags, and transported from the field to the lab for air drying. After each sample was air dried, it was sieved through a \#10 U.S. standard (2mm) sieve. Each sample was separated into a $<2 \mathrm{~mm}$ portion (fines) and a $>2 \mathrm{~mm}$ portion (rock fragments), the data collected from 2005-2007 was separated into a $<2 \mathrm{~mm}$ portion and sandstone $>2 \mathrm{~mm}$. Percent fines and percent rock fragments were determined on a per weight basis by dividing the weight of the individual portion by the weight of the whole soil sample. The fines portion of the soil samples were used to determine $\mathrm{pH}$, electrical conductivity, and extractable elements.

Soil $\mathrm{pH}$ was determined by mixing soil and distilled deionized water at a 1:1 ratio. Samples were mixed at 180 oscillations per minute for approximately 50 minutes. The soil $\mathrm{pH}$ was then determined using a Beckman $43 \mathrm{pH}$ meter. Electrical conductivity (EC) was used to 
determine the presence of soluble salts (Bower and Wilcox, 1965). Soil samples were mixed on a 2:1 ratio with distilled deionized water, mixed at 180 oscillations per minute for 15 minutes, and then allowed to equilibrate over night. After equilibrating, samples were measured with a handheld Milwaukee C65 EC Meter. A Mehlich 1 solution composed of $0.05 \mathrm{~N} \mathrm{HCl}$ and $0.025 \mathrm{~N}$ $\mathrm{H}_{2} \mathrm{SO}_{4}$ was used to obtain the extractable elements found in the soil (Mehlich, 1953). The leachate from each sample was analyzed for aluminum, calcium, iron, magnesium, manganese, phosphorus, potassium, and zinc using a Perkin Elmer Plasma 400 emission spectrometer.

Soil data were analyzed by one-way ANOVA by treatment combinations within year for $\mathrm{pH}$, percent fines, percent rock, EC, and extractable elements. Tukey's multiple comparison test was used to determine significant differences at $P<0.05$. Soil data were also analyzed by t-test among years within treatment combinations.

Ground cover data were analyzed by one-way ANOVA to compare cover types (herbaceous, litter, tree, bare ground/rock, water, and total cover) by soil treatment combinations for 2009. Tukey's multiple comparison test was used to determine significant differences at $P<$ 0.05 .

Tree data were analyzed using Proc GLM by substrate, compaction, depth, interactions, and species. Due to issues in the field from transitioning between students and unequal number of trees sampled, analysis of tree data was based on means for each treatment by species instead of measurements taken for each tree. Survival for 2008 and 2009 was calculated from estimated survival between 2005 and 2007 data. Significant differences for survival and volume were determined at $P<0.05$. 


\section{$\underline{\text { Results and Discussion }}$}

$\underline{\text { Soil }}$

The gray sandstone plots, $1.5 \mathrm{~m}$ gray compact $(5 \mathrm{G}-\mathrm{C})$ and $1.5 \mathrm{~m}$ gray noncompacted (5G-NC), had significantly greater pH levels in 2005 (7.6 and 8.3) and 2009 (7.7 and 8.1) compared to the brown sandstone treatments (Table 2-5). The brown sandstone treatments had $\mathrm{pH}$ levels ranging from 4.7 to 6.0 in 2005 and 4.6 to 6.1 in 2009 . These $\mathrm{pH}$ levels are similar to Showalter at al. (2010) who found mine soils sampled in Virginia to have $\mathrm{pH}$ levels of 5.53 for weathered brown sandstone mine soil and 8.86 for unweathered gray sandstone mine soil. There were no significant differences in $\mathrm{pH}$ within each treatment combination between 2005 and 2009. No decrease in the soil $\mathrm{pH}$ was found by Haering et al. (1993) who showed an initial decrease in $\mathrm{pH}$ after three years but then $\mathrm{pH}$ levels rebounded to near initial levels due to continued carbonate weathering and exposure to additional climatic factors.

The 5G-C and 5G-NC treatment combinations had significantly lower percent fines in 2005 (40 and 36\%) and 2009 (37\% for both) than all the brown sandstone treatments with the exception of the $1.2 \mathrm{~m}$ brown noncompacted (4B-NC) treatment in 2005 and the $1.5 \mathrm{~m}$ brown noncompacted (5B-NC) treatment in 2009 (Table 2-5). The $1.5 \mathrm{~m}$ brown compacted (5B-C) treatment showed a significant increase in percent fines of 51 to $60 \%$ from 2005 to 2009 . The greater amount of fines found in the brown sandstone treatments was expected due to the presence of some native topsoil and a higher level of weathering of the brown sandstone substrates before being placed at the surface during reclamation. Both brown and gray sandstone substrates are expected to weather rapidly after being placed on the surface and a greater amount of change was expected between 2005 and 2009 since a freeze-thaw study conducted by Angel et al. (2008) found that brown sandstone samples lost $64 \%$ of its mass compared to $35 \%$ for gray 
sandstone. However, due to climatic variation and differences in sandstone material, these results may be seen in the future as this study continues. Results for percent rock fragments are the exact opposite of those found for percent fines.

There were no significant differences for EC values within treatments in both 2005 and 2009 (Table 2-5). However, EC decreased significantly from 2005 to 2009 in all treatments but the 4B-NC. Decreases ranged from 0.10 to $0.40 \mathrm{dS} \mathrm{m}^{-1}$ across the six treatment combinations. All EC values were less than $1.0 \mathrm{dS} \mathrm{m}^{-1}$ which is considered acceptable for trees since EC values of $2.0 \mathrm{dS} \mathrm{m}^{-1}$ are thought to be marginally detrimental and values $>3.0 \mathrm{dS} \mathrm{m}^{-1}$ are considered toxic for plants on mined lands (Cummins et al., 1965).

Table 2-5. 2005 and 2009 soil properties in six soil treatments at Catenary Coal's Samples mine in Kanawha County, WV.

\begin{tabular}{|c|c|c|c|c|c|c|}
\hline \multirow[b]{2}{*}{ Properties } & \multicolumn{6}{|c|}{ Treatments $\uparrow$} \\
\hline & 4B-C & 4B-NC & 5B-C & 5B-NC & 5G-C & 5G-NC \\
\hline \multicolumn{7}{|l|}{$\mathrm{pH}$} \\
\hline 2005 & $4.7^{\mathrm{c} \ddagger}$ & $5.2^{\mathrm{bc}}$ & $6.0^{\mathrm{b}}$ & $4.7^{\mathrm{c}}$ & $7.6^{\mathrm{a}}$ & $8.3^{\mathrm{a}}$ \\
\hline 2009 & $4.7^{\mathrm{cd}}$ & $4.6^{\mathrm{d}}$ & $6.1^{\mathrm{b}}$ & $5.8^{\mathrm{bc}}$ & $7.7^{\mathrm{a}}$ & $8.1^{\mathrm{a}}$ \\
\hline \multicolumn{7}{|l|}{ Percent fines } \\
\hline 2005 & $50^{\mathrm{ab}}$ & $48^{\mathrm{ab}}$ & ${ }^{*} 51^{\mathrm{a}}$ & $54^{\mathrm{a}}$ & $40^{\mathrm{bc}}$ & $36^{\mathrm{c}}$ \\
\hline 2009 & $56^{\mathrm{ab}}$ & $55^{\mathrm{ab}}$ & $60^{\mathrm{a}}$ & $47^{\mathrm{bc}}$ & $37^{\mathrm{c}}$ & $37^{\mathrm{c}}$ \\
\hline \multicolumn{7}{|l|}{ Percent rock } \\
\hline 2005 & $50^{\mathrm{bc}}$ & $52^{\mathrm{bc}}$ & ${ }^{*} 49^{c}$ & $46^{\mathrm{c}}$ & $60^{\mathrm{ab}}$ & $64^{\mathrm{a}}$ \\
\hline 2009 & $44^{\mathrm{bc}}$ & $45^{\mathrm{bc}}$ & $40^{\mathrm{ab}}$ & $53^{\mathrm{ab}}$ & $63^{\mathrm{a}}$ & $63^{\mathrm{a}}$ \\
\hline \multicolumn{7}{|c|}{ Electrical conductivity $\left(\mathrm{dS} \mathrm{m}{ }^{-1}\right)$} \\
\hline 2005 & $* 0.53$ & 0.28 & ${ }^{*} 0.40$ & ${ }^{*} 0.43$ & ${ }^{*} 0.21$ & ${ }^{*} 0.20$ \\
\hline 2009 & 0.13 & 0.17 & 0.09 & 0.16 & 0.10 & 0.10 \\
\hline \multicolumn{7}{|c|}{$\dagger$ see Table 2-1 for treatment descriptions } \\
\hline $\begin{array}{l}\text { dmeans for ea } \\
\text { different at } P \\
* \text { denotes sign }\end{array}$ & ty wi & $\begin{array}{l}\text { ows wit } \\
\text { ithin the }\end{array}$ & e $\mathrm{s}$ & ette & $\mathrm{s}$ & cantly \\
\hline
\end{tabular}

Concentrations of extractable elements varied across treatment combinations and some significant differences were found among treatments and among years. The most notable difference was for $\mathrm{K}$ in which extractable potassium concentrations ranged from 0.17 to 0.20 $\mathrm{cmol}_{\mathrm{c}} \mathrm{kg}^{-1}$ in 2005 and 0.05 to $0.10 \mathrm{cmol}_{\mathrm{c}} \mathrm{kg}^{-1}$ in 2009 with significant decreases in all treatment 
combinations that ranged from 0.07 to $0.12 \mathrm{cmol}_{\mathrm{c}} \mathrm{kg}^{-1}$ from 2005 to 2009 . This could be due to $\mathrm{K}$ being absorbed by plants in larger amounts than any other nutrient except $\mathrm{N}$ or due to leaching since $\mathrm{K}$ leaching is common in coarse-texture soils in humid regions (Havlin et al., 2005). Another notable difference was for $\mathrm{P}$, which was significantly higher in the gray sandstone treatments in $2005\left(59\right.$ and $\left.63 \mathrm{mg} \mathrm{kg}^{-1}\right)$ and in 2009 (109 and $\left.108 \mathrm{mg} \mathrm{kg}^{-1}\right)$ when compared to the brown sandstone treatments, which ranged from 20 to $36 \mathrm{mg} \mathrm{kg}^{-1}$ in 2005 to 12 to $48 \mathrm{mg} \mathrm{kg}^{-1}$ in 2009. The concentration of $\mathrm{P}$ in the gray sandstone treatments also significantly increased from 59 and $63 \mathrm{mg} \mathrm{kg}^{-1}$ in 2005 to 109 and $108 \mathrm{mg} \mathrm{kg}^{-1}$ in 2009. Even though there was a large increase in extractable P in some treatments from 2005 to 2009, the P may not be plant available which is shown by sequential leaching studies conducted by Skousen and Emerson (2010). Extractable $\mathrm{Mg}$ and $\mathrm{Zn}$ showed no differences among years by treatment but there were some significant differences between treatments in 2009. The most notable difference being that $\mathrm{Zn}$ was significantly higher in the gray sandstone treatments ( 4.1 and $\left.4.0 \mathrm{mg} \mathrm{kg}^{-1}\right)$ compared to the brown sandstone treatments $\left(1.5\right.$ to $\left.2.3 \mathrm{mg} \mathrm{kg}^{-1}\right)$ in 2009 . 
Table 2-6. 2005 and 2009 Elemental concentrations in six soil treatments at Catenary

Coal's Samples mine in Kanawha County, WV.

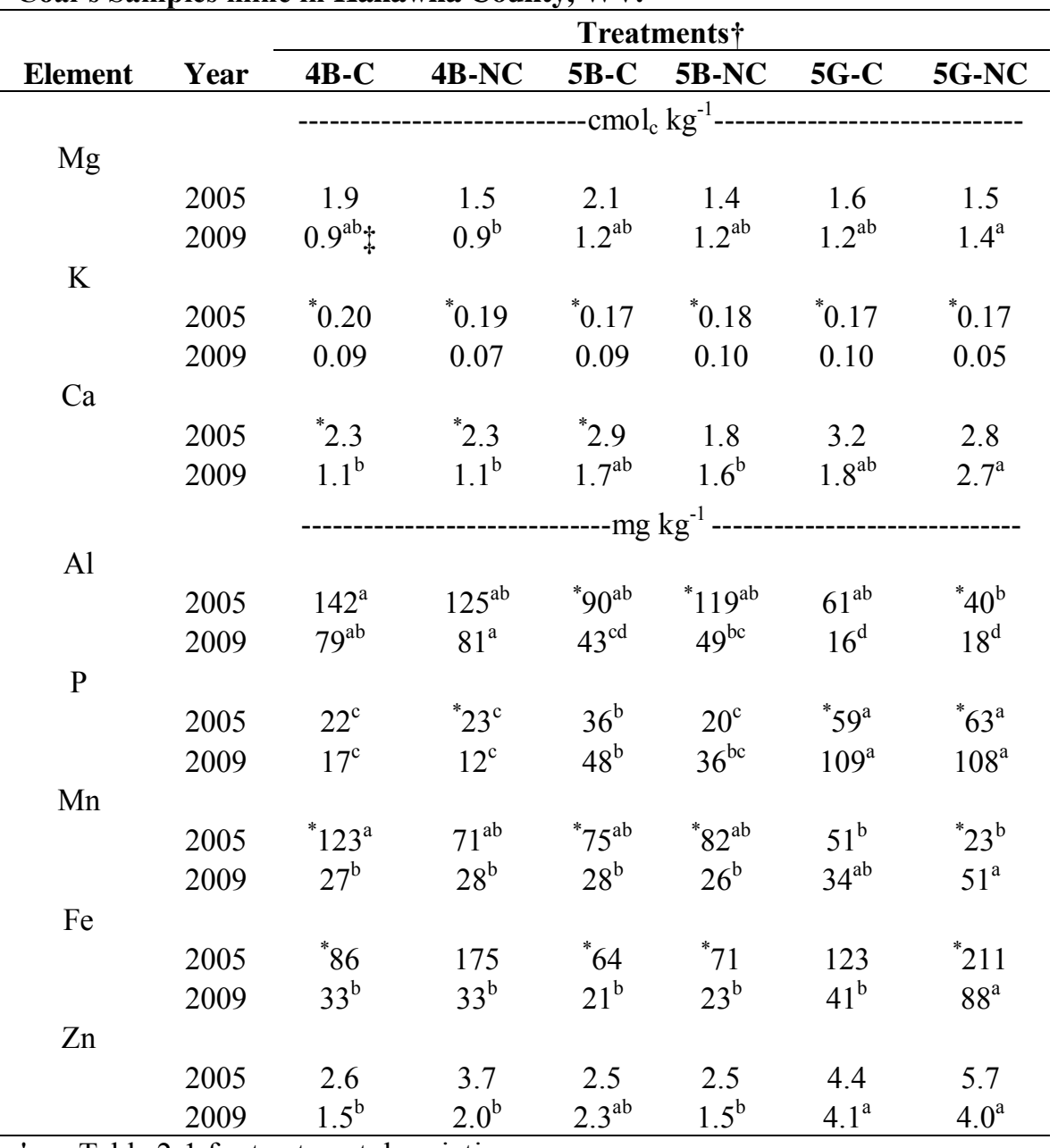

$\dagger$ see Table 2-1 for treatment descriptions

${ }^{\ddagger}$ means for each element within rows with the same letter are not significantly different at $P<0.05$

* denotes significantly different within that element between 2005 and 2009

\section{Ground cover}

The 5B-C treatment combination had significantly greater herbaceous ground cover at $80 \%$ while the remaining treatment combinations ranged from 3 to $47 \%$ (Table $2-7$ ). Due to the higher $\mathrm{pH}$ found in the gray sandstone treatments which is more favorable to herbaceous plants, the low amount of herbaceous ground cover was unexpected. It's possible that these treatments did not receive a hydroseed application like the brown treatment combinations. Few significant differences were found for litter cover and ranged from 0 to $2 \%$ across the six treatment 
combinations. No significant differences were found for the percentage of tree cover ( 0.3 to $7 \%)$ across the six soil treatment combinations. Total ground cover was significantly greater on the 5B-C treatment combination ( $84 \%$ ) while the $5 \mathrm{G}-\mathrm{C}$ and $5 \mathrm{G}-\mathrm{NC}$ treatment combinations were significantly less than the other brown treatment combinations. Results for the percentage of bare ground or rock were exact opposites of the total cover found in each treatment combination. The 5B-NC treatment combination had a significant amount of standing water covering the soil surface $(5 \%)$ which was greater than all other treatments.

Table 2-7. 2009 ground cover on six soil treatments at Catenary Coal's Samples mine in Kanawha County, WV.

\begin{tabular}{lccccccc}
\hline & \multicolumn{7}{c}{ Treatments $\dagger^{\dagger}$} \\
\cline { 2 - 8 } Cover & 4B-C & 4B-NC & 5B-C & 5B-NC & 5G-C & 5G-NC & Avg. \\
\hline Herbaceous & $44^{\mathrm{b}}$ & $32^{\mathrm{b}}$ & $80^{\mathrm{a}}$ & $47^{\mathrm{b}}$ & $3^{\mathrm{c}}$ & $5^{\mathrm{c}}$ & 38 \\
Litter & $0.4^{\mathrm{ab}}$ & $2^{\mathrm{a}}$ & $0^{\mathrm{b}}$ & $0.3^{\mathrm{b}}$ & $0^{\mathrm{b}}$ & $0.2^{\mathrm{b}}$ & 0.5 \\
Tree & $6^{\mathrm{a}}$ & $7^{\mathrm{a}}$ & $4^{\mathrm{a}}$ & $7^{\mathrm{a}}$ & $1^{\mathrm{a}}$ & $0.3^{\mathrm{a}}$ & 4 \\
Total & $50^{\mathrm{b}}$ & $41^{\mathrm{b}}$ & $84^{\mathrm{a}}$ & $54^{\mathrm{b}}$ & $3^{\mathrm{c}}$ & $5^{\mathrm{c}}$ & 43 \\
& & & & & & & \\
Bare/rock & $48^{\mathrm{b}}$ & $59^{\mathrm{b}}$ & $16^{\mathrm{c}}$ & $40^{\mathrm{b}}$ & $97^{\mathrm{a}}$ & $95^{\mathrm{a}}$ & 56 \\
Water & $0^{\mathrm{b}}$ & $0.3^{\mathrm{ab}}$ & $0^{\mathrm{b}}$ & $5^{\mathrm{a}}$ & $0^{\mathrm{b}}$ & $0^{\mathrm{b}}$ & 1 \\
\hline
\end{tabular}

†see Table 2-1 for treatment descriptions

means for each cover within rows with the same letter are not significantly different at $P<0.05$

$\underline{\text { Tree survival and volume }}$

After five growing seasons, there were 424 trees sampled across all species and soil treatment combinations (Table 2-8). This translates into an estimated 1342 trees per hectare but does not include volunteer species that have become established on the site. Trees sampled by species across treatment combinations ranged from 7 for black cherry to 179 for three combined oak species and by treatment across species with 58 for both the $5 \mathrm{G}-\mathrm{C}$ and $5 \mathrm{G}-\mathrm{NC}$ treatments to 87 for the 4B-NC treatment. Trees sampled by species and treatment combination ranged from zero for black cherry and redbud in the 5G-C treatment to 44 for the three combined oak species in the 4B-NC treatment. 
Table 2-8. Total number of trees sampled after five growing seasons in six soil treatments at Catenary Coal's Samples mine in Kanawha County, WV.

\begin{tabular}{lccccccc}
\hline & \multicolumn{7}{c}{ Treatments $\dagger$} \\
\cline { 2 - 8 } Species & 4B-C & 4B-NC & 5B-C & 5B-NC & 5G-C & 5G-NC & Total \\
\hline Black cherry & 1 & 1 & 2 & 2 & 0 & 1 & 7 \\
Black locust & 3 & 10 & 10 & 3 & 2 & 3 & 31 \\
Dogwood & 1 & 3 & 1 & 3 & 6 & 1 & 15 \\
Oak & 22 & 44 & 27 & 37 & 21 & 28 & 179 \\
Redbud & 1 & 5 & 2 & 2 & 0 & 2 & 12 \\
Sugar maple & 3 & 7 & 8 & 6 & 7 & 2 & 33 \\
Tulip poplar & 7 & 2 & 5 & 7 & 6 & 4 & 31 \\
White ash & 20 & 11 & 15 & 15 & 9 & 10 & 80 \\
White pine & 5 & 4 & 9 & 4 & 7 & 7 & 36 \\
Total & 63 & 87 & 79 & 79 & 58 & 58 & 424 \\
\hline
\end{tabular}

$\dagger$ see Table 2-1 for treatment descriptions

There were no significant differences found for survival by substrate, compaction, or depth of treatments and few significant differences were found by interactions and by species (Table 2-9). The survival in the 4B-NC treatment combination (79\%) was significantly greater than the 5B-NC treatment $(50 \%)$, while the remaining interactions showed no significant difference. Black locust had significantly greater survival (77\%) than white pine (50\%) and no significant differences were found for the remaining tree species. Volume was significantly greater in brown sandstone treatments at $1840 \mathrm{~cm}^{3}$ when compared to the gray sandstone treatments at $176 \mathrm{~cm}^{3}$. There were no significant differences for volume by compaction or depth of treatments. There were significant differences for volume by treatment interactions with brown and gray main treatments being significantly different. Black locust had significantly greater volume $\left(7361 \mathrm{~cm}^{3}\right)$ than all other species which had volumes ranging from $111 \mathrm{~cm}^{3}$ to $998 \mathrm{~cm}^{3}$. 
Table 2-9 Treatment effects for volume and survival after

five growing seasons in six soil treatments at Catenary Coal's

Samples mine in Kanawha County, WV.

\begin{tabular}{llcc}
\hline & & Survival & Volume \\
\hline Substrate & & $\%$ & $\mathrm{~cm} 3$ \\
& Brown & $66^{\mathrm{a}}$ & $1840^{\mathrm{a}}$ \\
Compaction & Gray & $68^{\mathrm{a}}$ & $176^{\mathrm{b}}$ \\
& Compacted & $66^{\mathrm{a}}$ & $1095^{\mathrm{a}}$ \\
& Noncompacted & $66^{\mathrm{a}}$ & $1544^{\mathrm{a}}$ \\
& & & \\
Depth & $1.2 \mathrm{~m}$ depth & $72^{\mathrm{a}}$ & $1555^{\mathrm{a}}$ \\
& 1.5 m depth & $63^{\mathrm{a}}$ & $1208^{\mathrm{a}}$ \\
& & & \\
& 4B-C & $66^{\mathrm{ab}}$ & $1052^{\mathrm{a}}$ \\
& 4B-NC & $79^{\mathrm{a}}$ & $2058^{\mathrm{a}}$ \\
& 5B-C & $67^{\mathrm{ab}}$ & $1842^{\mathrm{a}}$ \\
& 5B-NC & $50^{\mathrm{b}}$ & $2409^{\mathrm{a}}$ \\
& 5G-C & $65^{\mathrm{ab}}$ & $191^{\mathrm{b}}$ \\
& 5G-NC & $70^{\mathrm{ab}}$ & $165^{\mathrm{b}}$ \\
& & & \\
& Black cherry & $53^{\mathrm{ab}}$ & $998^{\mathrm{b}}$ \\
& Black locust & $77^{\mathrm{a}}$ & $7361^{\mathrm{a}}$ \\
& Dogwood & $71^{\mathrm{ab}}$ & $867^{\mathrm{b}}$ \\
& Oak & $68^{\mathrm{ab}}$ & $638^{\mathrm{b}}$ \\
& Redbud & $71^{\mathrm{ab}}$ & $638^{\mathrm{b}}$ \\
& sugar maple & $73^{\mathrm{ab}}$ & $111^{\mathrm{b}}$ \\
& Tulip poplar & $57^{\mathrm{ab}}$ & $627^{\mathrm{b}}$ \\
& White ash & $76^{\mathrm{ab}}$ & $518^{\mathrm{b}}$ \\
& White pine & $50^{\mathrm{b}}$ & $211^{\mathrm{b}}$ \\
& Average & 66 & 1328 \\
\hline & & &
\end{tabular}

The average tree survival, volume, and vigor rating for all species across the six soil treatment combinations was $67 \%, 1309 \mathrm{~cm}^{3}$, and good to very good (4.2) after five growing seasons (Table 2-10, 2-11, 2-12). The average survival across the six treatment combinations ranged from $50 \%$ for white pine to $77 \%$ for black locust, average volume ranged from $111 \mathrm{~cm}^{3}$ for sugar maple to $7361 \mathrm{~cm}^{3}$ for black locust, and average vigor rating ranged from moderate (3.0) for sugar maple to good to very good (4.7) for black cherry. The average survival for trees across species ranged from $56 \%$ in the $5 \mathrm{~B}-\mathrm{NC}$ treatment to $79 \%$ in the $4 \mathrm{~B}-\mathrm{NC}$, average volume ranged from $165 \mathrm{~cm}^{3}$ in the $5 \mathrm{G}-\mathrm{NC}$ treatment to $2409 \mathrm{~cm}^{3}$ in the5B-NC, and the average vigor 
rating ranged from moderate to good (3.9) in the 5G-NC treatment to good to very good (4.7) in the 5B-C.

Table 2-10. Average survival of tree species after five growing seasons in six soil treatments at Catenary Coal's Samples mine in Kanawha County, WV.

\begin{tabular}{lccccccc}
\hline \multirow{2}{*}{ Species } & \multicolumn{7}{c}{ Treatments $\dagger$} \\
\cline { 2 - 8 } & 4B-C & 4B-NC & 5B-C & 5B-NC & 5G-C & 5G-NC & Avg. \\
\hline Black cherry & 67 & 100 & 50 & 50 & 0 & 50 & 53 \\
Black locust & 60 & 63 & 91 & 50 & 100 & 100 & 77 \\
Dogwood & 100 & 86 & 33 & 63 & 86 & 60 & 71 \\
Oaks & 54 & 85 & 69 & 58 & 70 & 74 & 68 \\
Redbud & 83 & 100 & 100 & 44 & 0 & 100 & 71 \\
Sugar maple & 75 & 93 & 69 & 43 & 88 & 67 & 73 \\
Tulip poplar & 22 & 56 & 55 & 53 & 82 & 73 & 57 \\
White ash & 79 & 77 & 80 & 60 & 100 & 60 & 76 \\
White pine & 50 & 51 & 60 & 33 & 63 & 42 & 50 \\
Avg. & 66 & 79 & 67 & 56 & 65 & 70 & 66 \\
\hline
\end{tabular}

†see Table 2-1 for treatment descriptions

Table 2-11. Average volume of tree species after five growing seasons in six soil treatments at Catenary Coal's Samples mine in Kanawha County, WV.

\begin{tabular}{|c|c|c|c|c|c|c|c|}
\hline \multirow[b]{2}{*}{ Species } & \multicolumn{7}{|c|}{ Treatments $\dagger$} \\
\hline & 4B-C & 4B-NC & 5B-C & 5B-NC & 5G-C & 5G-NC & Avg. \\
\hline & & & & $\mathrm{cm}^{3}$ & & 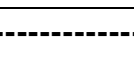 & \\
\hline Black cherry & 812 & 2718 & 945 & 395 & . & 120 & 998 \\
\hline Black locust & 4082 & 9866 & 12565 & 17157 & 24 & 469 & 7361 \\
\hline Dogwood & 596 & 1664 & 1060 & 1372 & 494 & 14 & 867 \\
\hline Oaks & 694 & 961 & 414 & 454 & 124 & 71 & 453 \\
\hline Redbud & 1423 & 959 & 412 & 388 & • & 7 & 638 \\
\hline Sugar maple & 145 & 136 & 191 & 123 & 40 & 28 & 111 \\
\hline Tulip poplar & 475 & 1129 & 148 & 1043 & 322 & 646 & 627 \\
\hline White ash & 680 & 863 & 633 & 563 & 283 & 85 & 518 \\
\hline White pine & 560 & 225 & 210 & 183 & 47 & 42 & 211 \\
\hline Avg. & 1052 & 2058 & 1842 & 2409 & 191 & 165 & 1328 \\
\hline
\end{tabular}


Table 2-12. Average vigor rating of tree species after five growing seasons in six soil treatments at Catenary Coal's Samples mine in Kanawha County, WV.

\begin{tabular}{lccccccc}
\hline & \multicolumn{7}{c}{ Treatments $\dagger$} \\
\cline { 2 - 8 } Species & 4B-C & 4B-NC & 5B-C & 5B-NC & 5G-C & 5G-NC & Avg. \\
\hline Black cherry & 4.0 & 5.0 & 5.0 & 4.5 &. & 5.0 & 4.7 \\
Black locust & 3.7 & 4.7 & 4.9 & 4.7 & 5.0 & 4.3 & 4.5 \\
Dogwood & 4.0 & 4.7 & 5.0 & 5.0 & 4.2 & 3.0 & 4.3 \\
Oaks & 4.6 & 5.0 & 4.7 & 4.8 & 3.6 & 2.9 & 4.3 \\
Redbud & 5.0 & 3.6 & 5.0 & 4.0 &. & 4.5 & 4.4 \\
Sugar maple & 2.7 & 3.1 & 3.6 & 3.2 & 2.6 & 3.0 & 3.0 \\
Tulip poplar & 3.1 & 3.5 & 4.2 & 4.1 & 3.8 & 3.5 & 3.7 \\
White ash & 4.0 & 4.5 & 4.7 & 4.0 & 4.2 & 3.8 & 4.2 \\
White pine & 5.0 & 5.0 & 5.0 & 5.0 & 4.9 & 4.7 & 4.9 \\
Avg. & 4.0 & 4.3 & 4.7 & 4.4 & 4.0 & 3.9 & 4.2 \\
\hline
\end{tabular}

$\dagger$ see Table 2-1 for treatment descriptions

Black cherry had the third lowest average survival across the six soil treatment combinations at $61 \%$ with an average volume of $998 \mathrm{~cm}^{3}$ and a good to very good vigor rating of 4.7. The highest average survival $(100 \%)$ was recorded in the 4B-NC treatment while the lowest $(0 \%)$ was recorded in the $5 \mathrm{G}-\mathrm{C}$ treatment. The greatest volume $\left(2718 \mathrm{~cm}^{3}\right)$ was recorded in the 4B-NC treatment while the lowest $\left(120 \mathrm{~cm}^{3}\right)$ was recorded in the $5 \mathrm{G}-\mathrm{NC}$ treatment. The highest average vigor rating (5.0) was recorded in the $4 \mathrm{~B}-\mathrm{NC}, 5 \mathrm{~B}-\mathrm{C}$, and the $5 \mathrm{G}-\mathrm{NC}$ treatments while the lowest (4.0) was recorded in the 4B-C treatment. Species survival, height, diameter, and volume for five growing seasons can be seen in Figures 2-1a through 2-1d. Black cherry had mixed results for tree performance which could be to the low number of trees that were sampled in each treatment. The low number of trees may have confounded the results so that survival and growth trends for this species are unclear. 


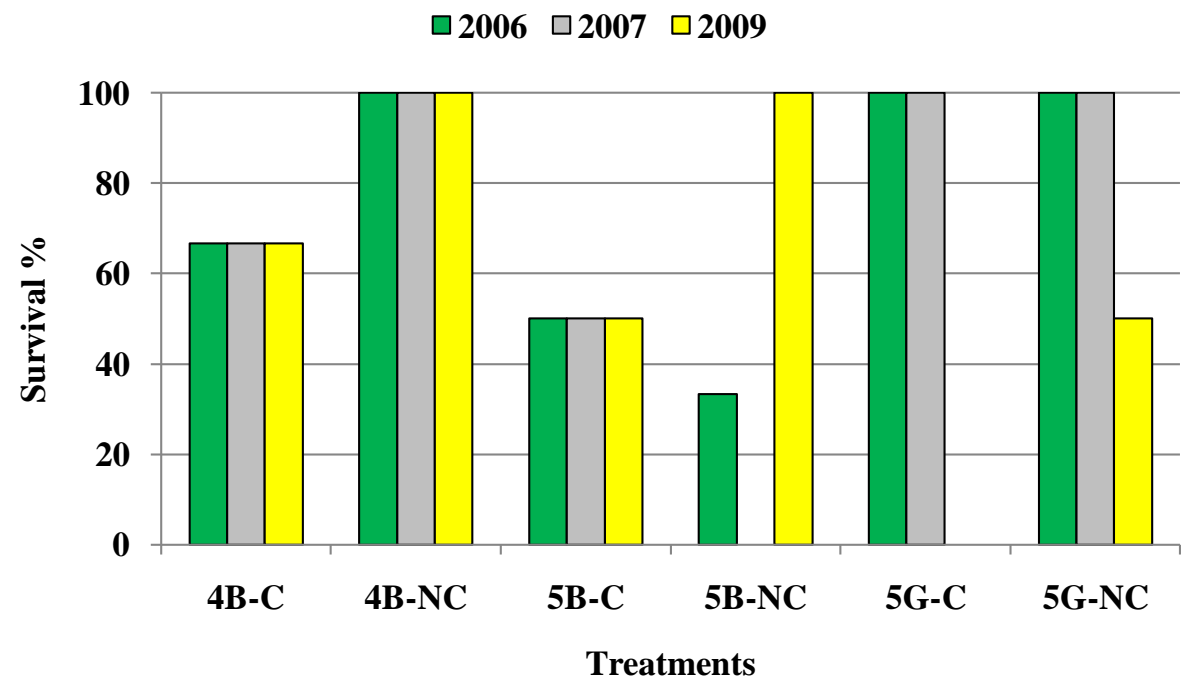

Figure 2-1a. Average survival of black cherry for three growing seasons in six soil treatments at Catenary Coal's Samples mine in Kanawha County, WV.

$4 \mathrm{~B}-\mathrm{C}=1.2 \mathrm{~m}$ brown sandstone compacted, 4B-NC $=1.2 \mathrm{~m}$ brown sandstone noncompacted, $1.5 \mathrm{~m}$ brown sandstone compacted, $5 \mathrm{~B}-\mathrm{NC}=1.5 \mathrm{~m}$ brown sandstone noncompacted, $5 \mathrm{G}-\mathrm{C}=1.5 \mathrm{~m}$ gray sandstone compacted, $5 \mathrm{G}-\mathrm{NC}=1.5$ $\mathrm{m}$ gray noncompacted

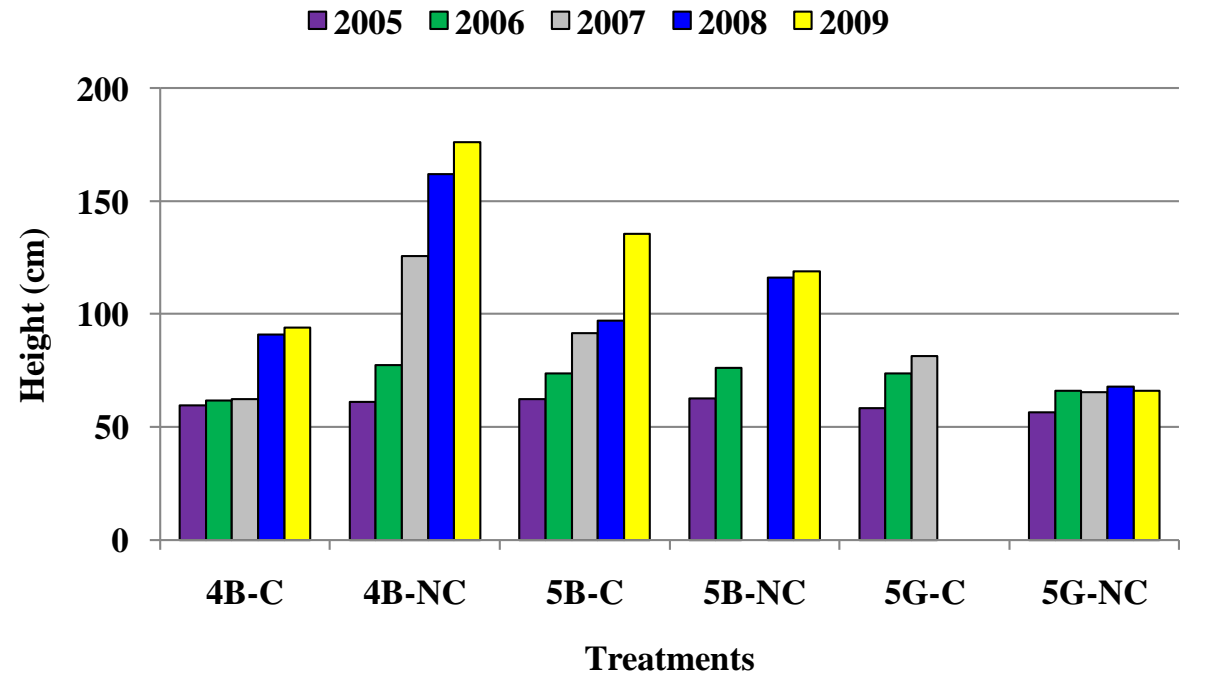

Figure 2-1b. Average height of black cherry for five growing seasons in six soil treatments at Catenary Coal's Samples mine in Kanawha County, WV. 


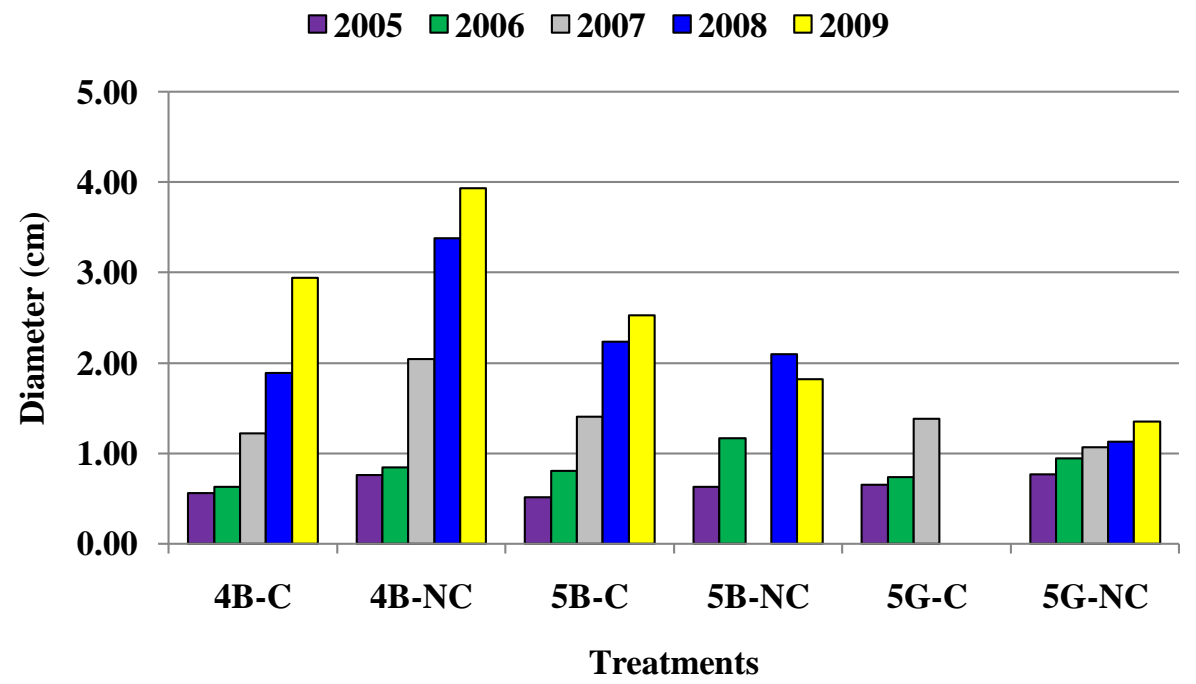

Figure 2-1c. Average diameter of black cherry for five growing seasons in six soil treatments at Catenary Coal's Samples mine in Kanawha County, WV.

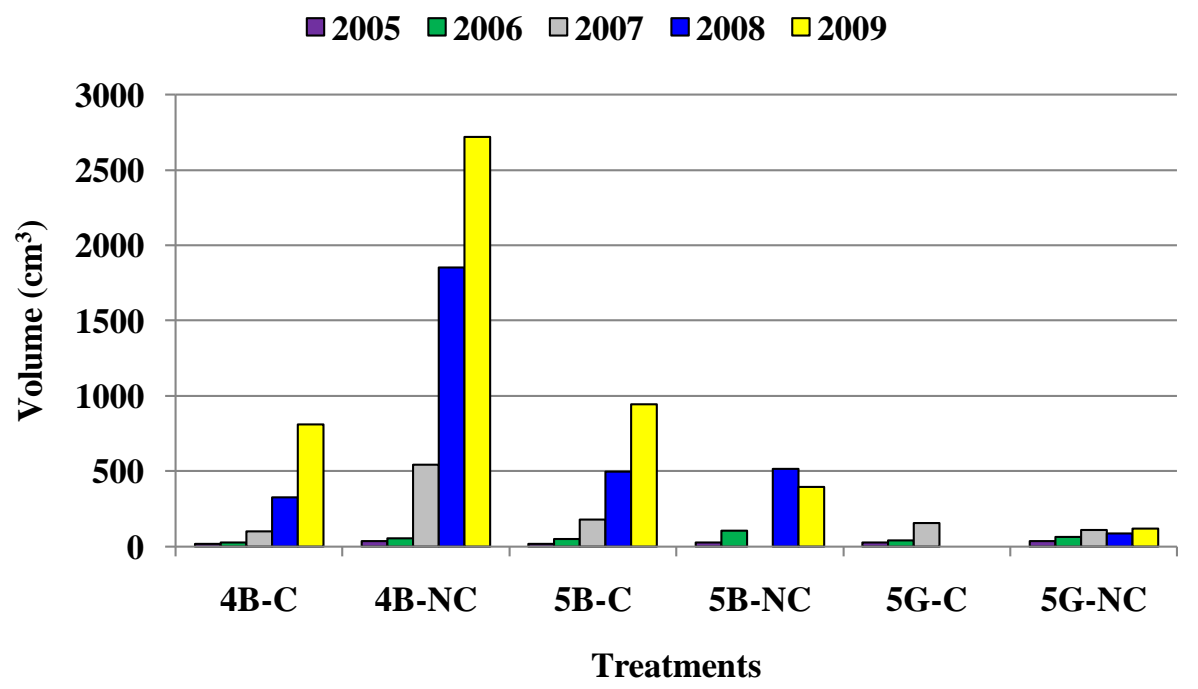

Figure 2-1d. Average volume of black cherry for five growing seasons in six soil treatments at Catenary Coal's Samples mine in Kanawha County, WV.

Black locust had the highest average survival across the six soil treatment combinations at $77 \%$ with an average volume of $7361 \mathrm{~cm}^{3}$ and a good to very good vigor rating of 4.5 . The highest average survival (100\%) was recorded in the 5G-C and 5G-NC treatments while the lowest $(50 \%)$ was recorded in the $5 \mathrm{~B}-\mathrm{C}$. The greatest average volume $\left(17157 \mathrm{~cm}^{3}\right)$ was recorded in the 5B-NC while the lowest $\left(24 \mathrm{~cm}^{3}\right)$ was recorded in the 5G-C treatment. The highest average vigor rating (5.0) was recorded in the 5G-C treatment while the lowest (3.7) was 
recorded in the 4B-C treatment. Species survival, height, diameter, and volume for the length of the study can be seen in Figures 2-2a through 2-2d. This species grew by far the best of the species planted on this site. Growth was especially impressive during 2008 and 2009 (Figure 22d), and volume increased three times from between 2008 and 2009.

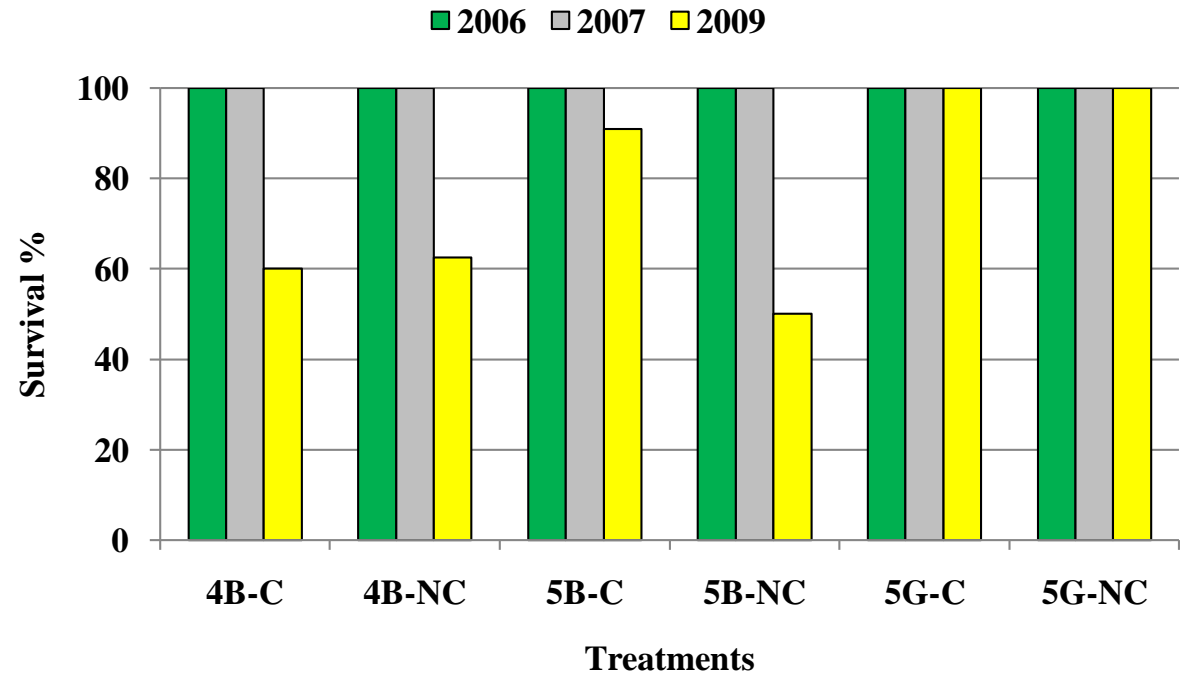

Figure 2-2a. Average survival of black locust for three growing seasons in six soil treatments at Catenary Coal's Samples mine in Kanawha County, WV.

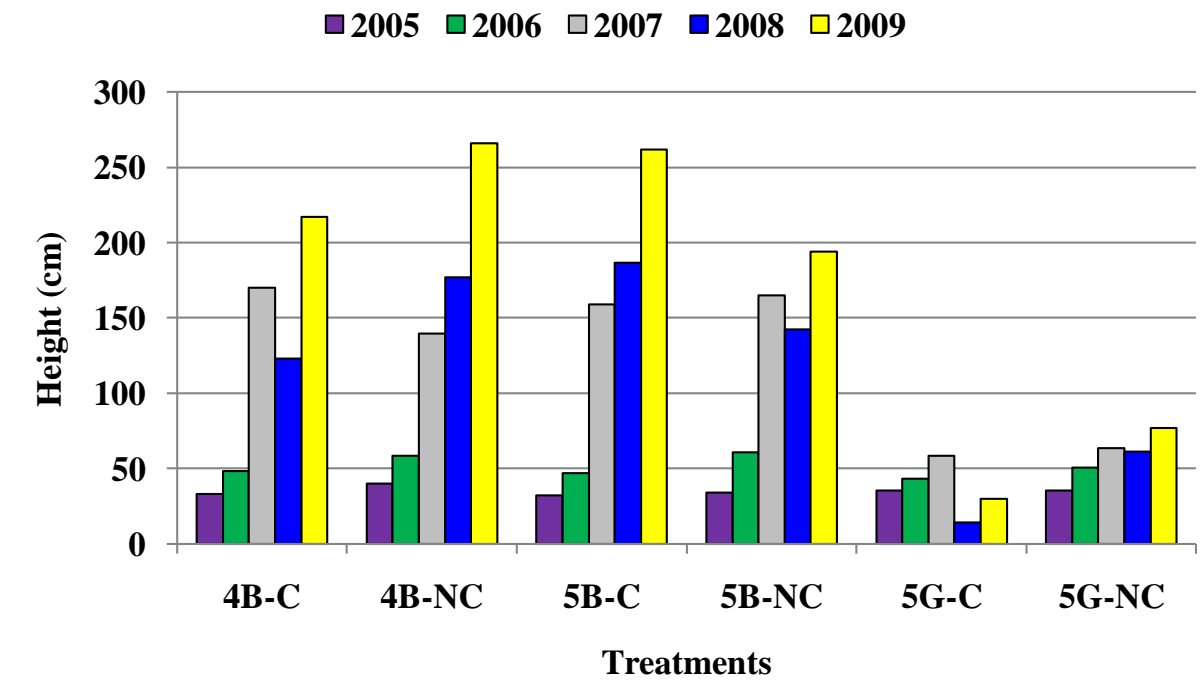

Figure 2-2b. Average height of black locust for five growing seasons in six soil treatments at Catenary Coal's Samples mine in Kanawha County, WV. 


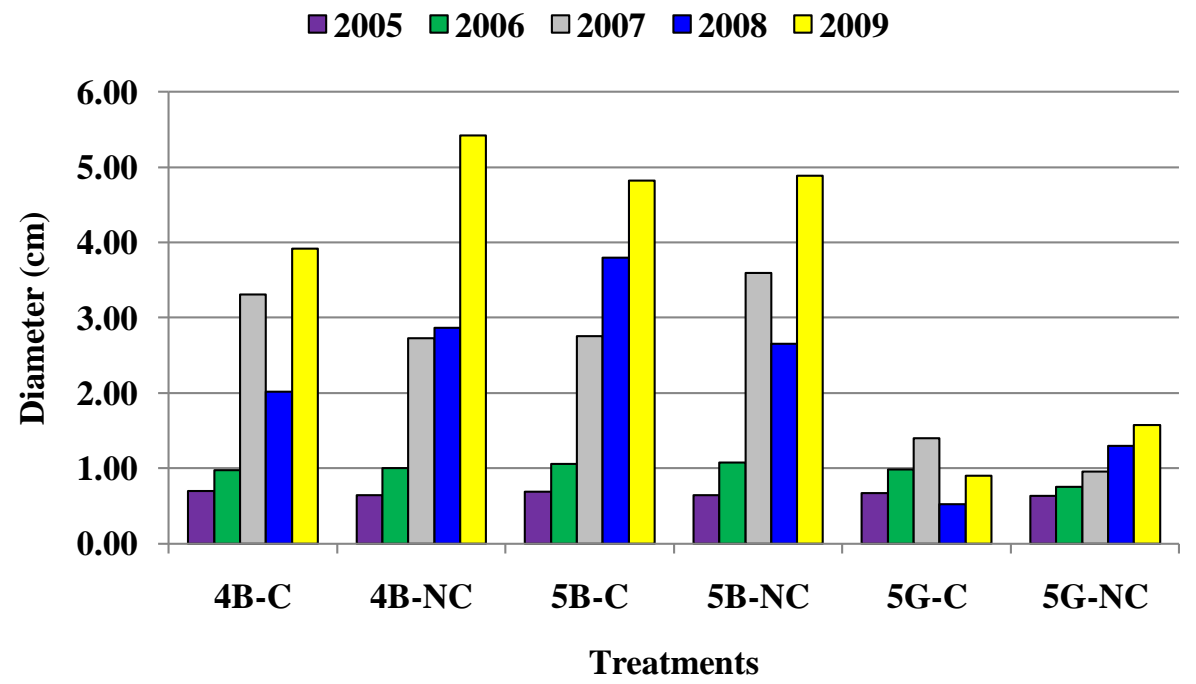

Figure 2-2c. Average diameter of black locust for five growing seasons in six soil treatments at Catenary Coal's Samples mine in Kanawha County, WV.

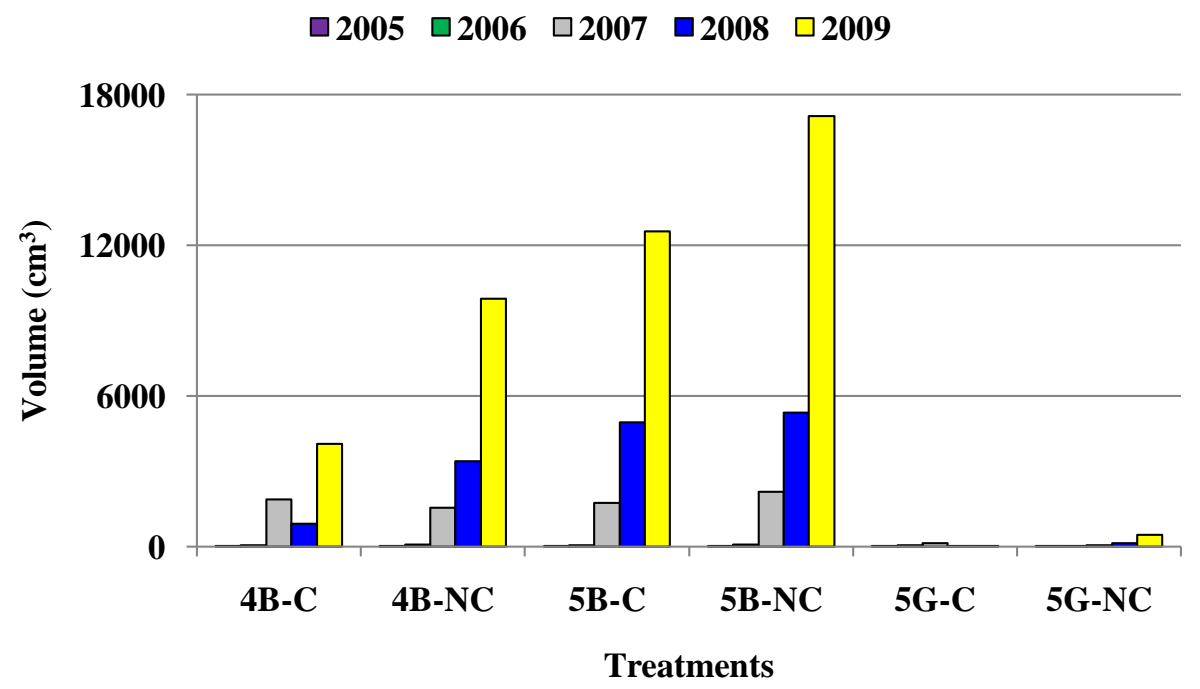

Figure 2-2d. Average volume of black locust for five growing seasons in six soil treatments at Catenary Coal's Samples mine in Kanawha County, WV.

Dogwood had the fourth highest average survival across the six treatment combinations at $71 \%$ with an average volume of $867 \mathrm{~cm}^{3}$ and good to very good vigor rating of 4.3 . The highest average survival (100\%) was recorded in the 4B-C treatment while the lowest (33\%) was recorded in the 5B-C treatment. The greatest average volume $\left(1664 \mathrm{~cm}^{3}\right)$ was recorded in the 4B$\mathrm{NC}$ treatment while the lowest $\left(14 \mathrm{~cm}^{3}\right)$ was recorded in the 5G-NC treatment. The highest average vigor rating (5.0) was recorded in the 5B-C and 5B-NCtreatments while the lowest (3.0) 
was recorded in the 5G-NC treatment. Species survival, height, diameter, and volume for the length of the study can be seen in Figures 2-3a through 2-3d. Increases in volume for dogwood were remarkably good from 2008 to 2009 especially in the brown sandstone plots (Figure 2-3d). Dogwood had greater growth in the noncompacted plots in both brown sandstone treatments but not in the gray sandstone treatments.

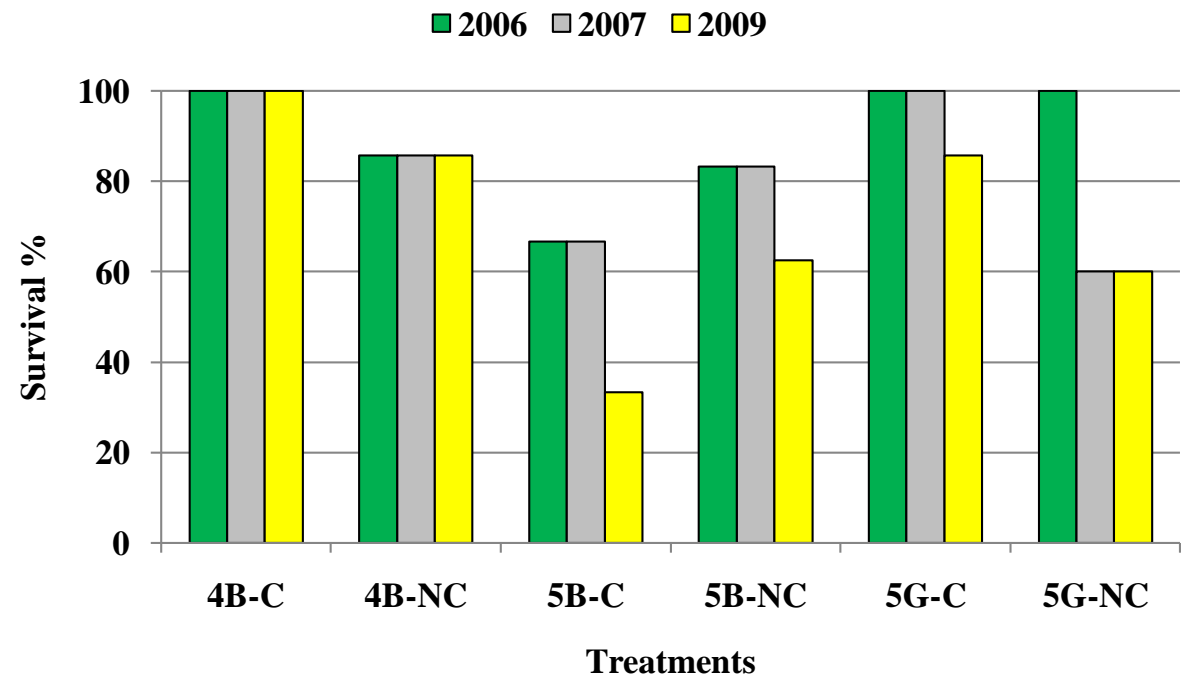

Figure 2-3a. Average survival of dogwood for three growing seasons in six soil treatments at Catenary Coal's Samples mine in Kanawha County, WV.

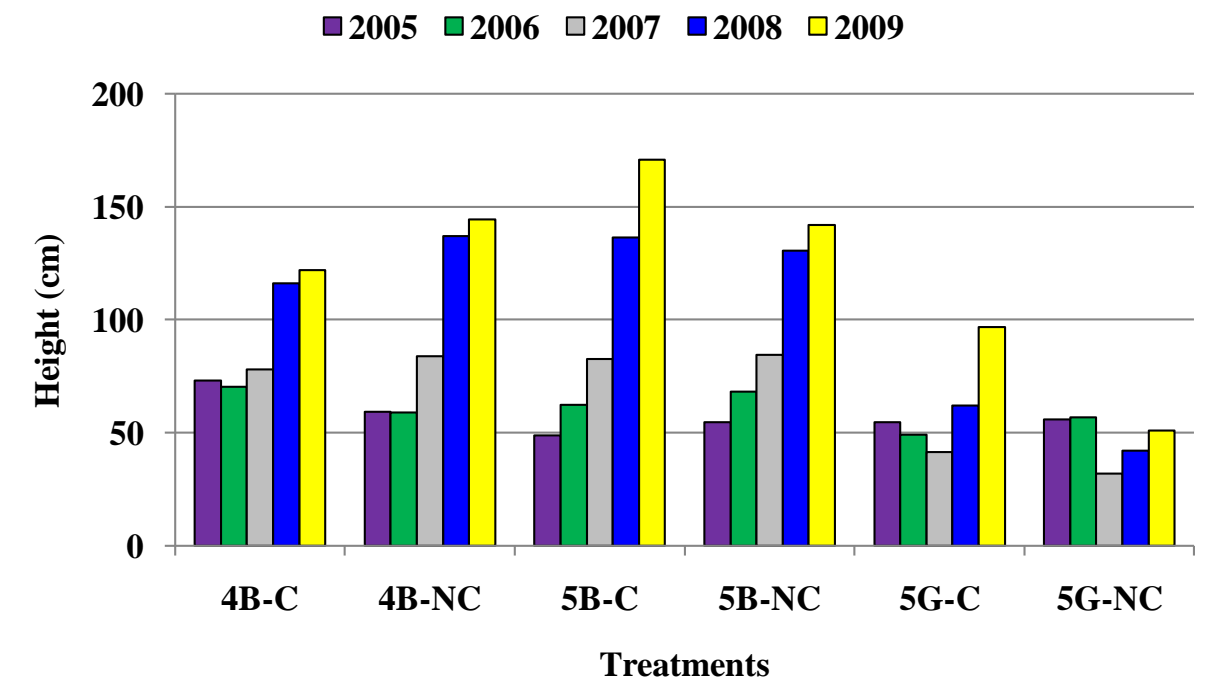

Figure 2-3b. Average height of dogwood for five growing seasons in six soil treatments at Catenary Coal's Samples mine in Kanawha County, WV. 


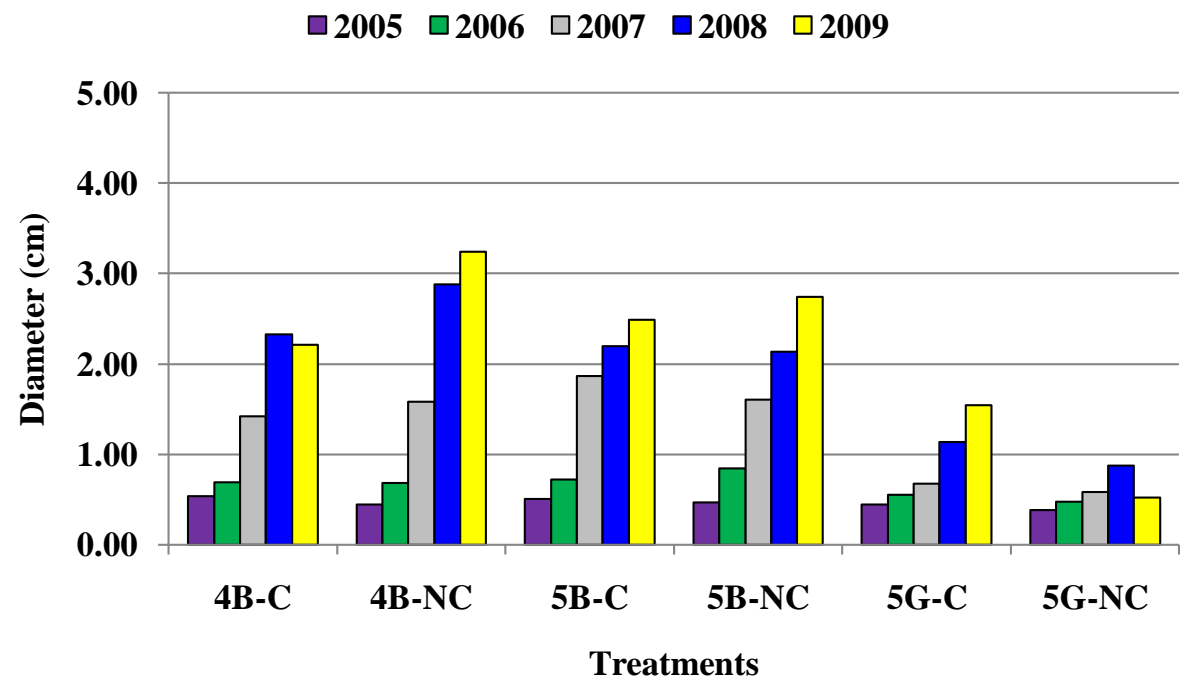

Figure 2-3c. Average diameter of dogwood for five growing seasons in six soil treatments at Catenary Coal's Samples mine in Kanawha County, WV.

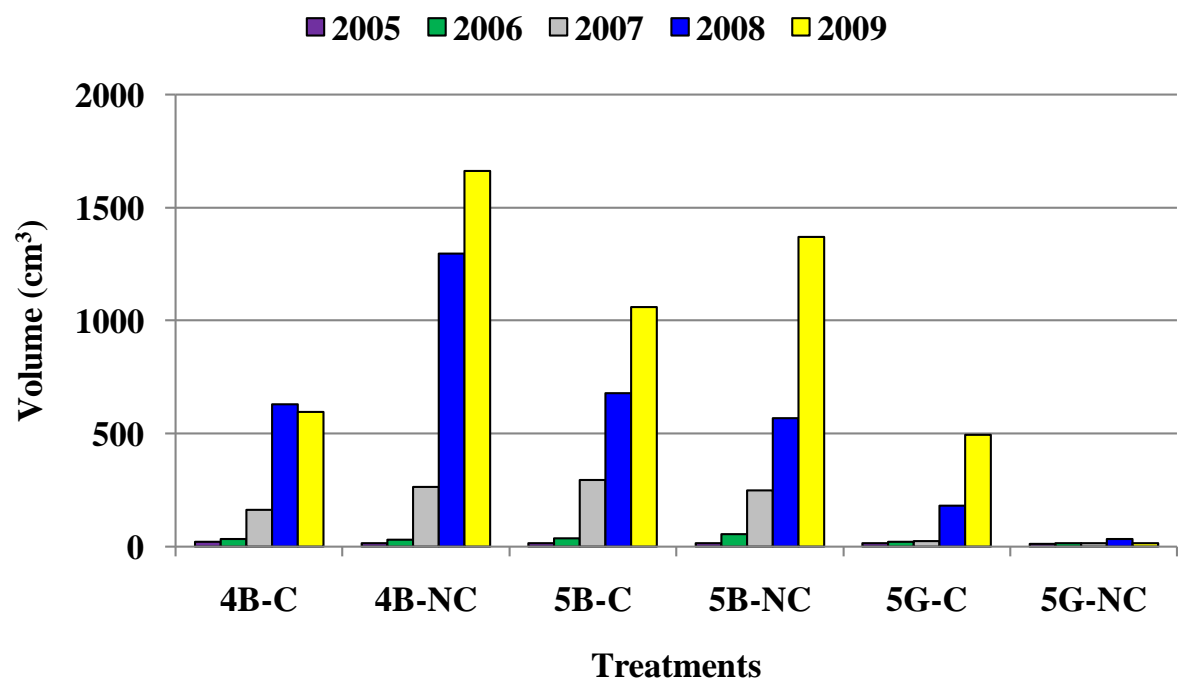

Figure 2-3d. Average volume of dogwood for five growing seasons in six soil treatments at Catenary Coal's Samples mine in Kanawha County, WV.

The three oak species (chestnut, red, and white), as well as redbud, had the fourth lowest survival across the six soil treatment combinations with an average volume of $453 \mathrm{~cm}^{3}$ and a good to very good vigor rating of 4.3 . The highest average survival (85\%) was recorded in the 4B-NC treatment while the lowest (54\%) was recorded in the $4 \mathrm{~B}-\mathrm{C}$ treatment. The greatest average volume $\left(961 \mathrm{~cm}^{3}\right)$ was recorded in the $4 \mathrm{~B}-\mathrm{NC}$ treatment while the lowest $\left(71 \mathrm{~cm}^{3}\right)$ was recorded in the 5G-NC treatment. The highest average vigor rating (5.0) was recorded in the 4B- 
$\mathrm{NC}$ treatment while the lowest (2.9) was recorded in the 5G-NC treatment. Species survival, height, diameter, and volume for the length of the study can be seen in Figures 2-4a through 24d. The three oak species showed greater volume in the brown sandstone plots and the noncompacted plots indicating possible limiting factors of moisture, compaction, and $\mathrm{pH}$.

$\square 2006 \square 2007 \square 2009$

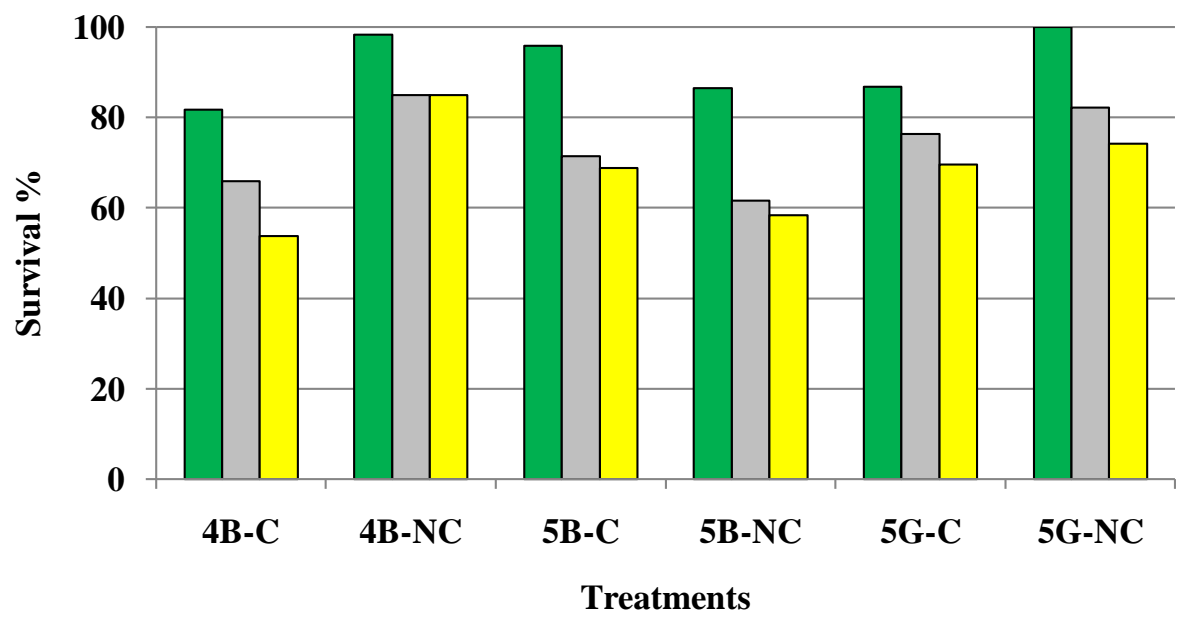

Figure 2-4a. Average survival of oak for three growing seasons in six soil treatments at Catenary Coal's Samples mine in Kanawha County, WV.

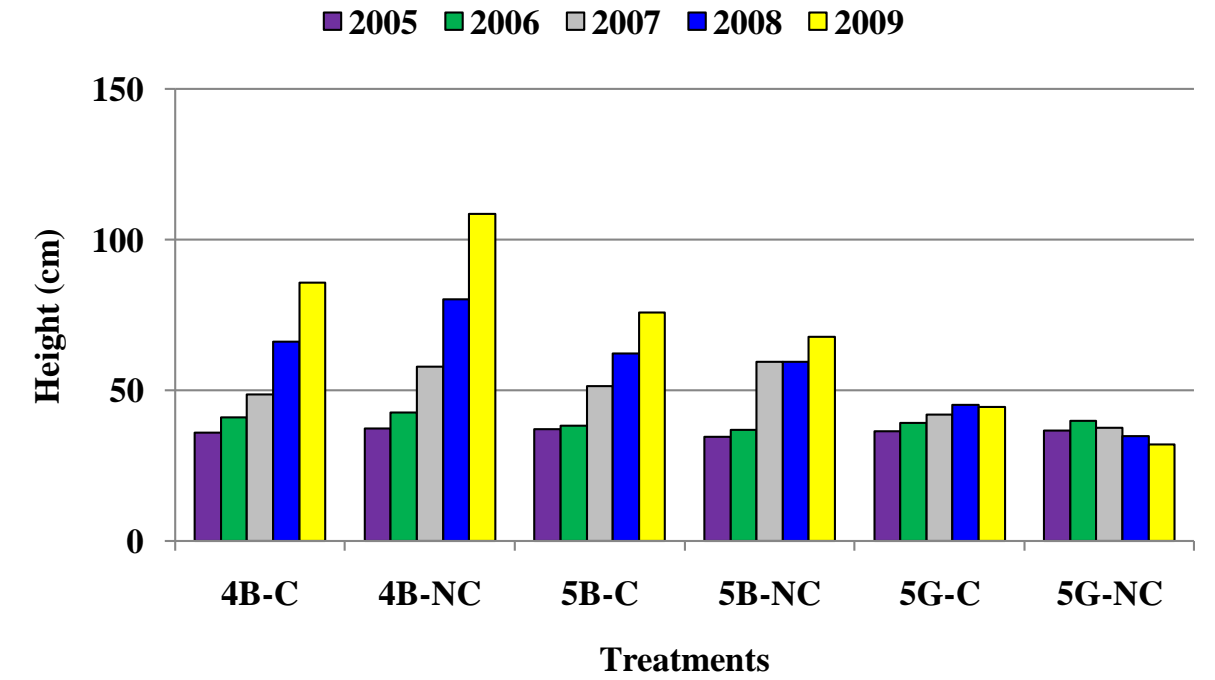

Figure 2-4b. Average height of oak for five growing seasons in six soil treatments at Catenary Coal's Samples mine in Kanawha County, WV. 


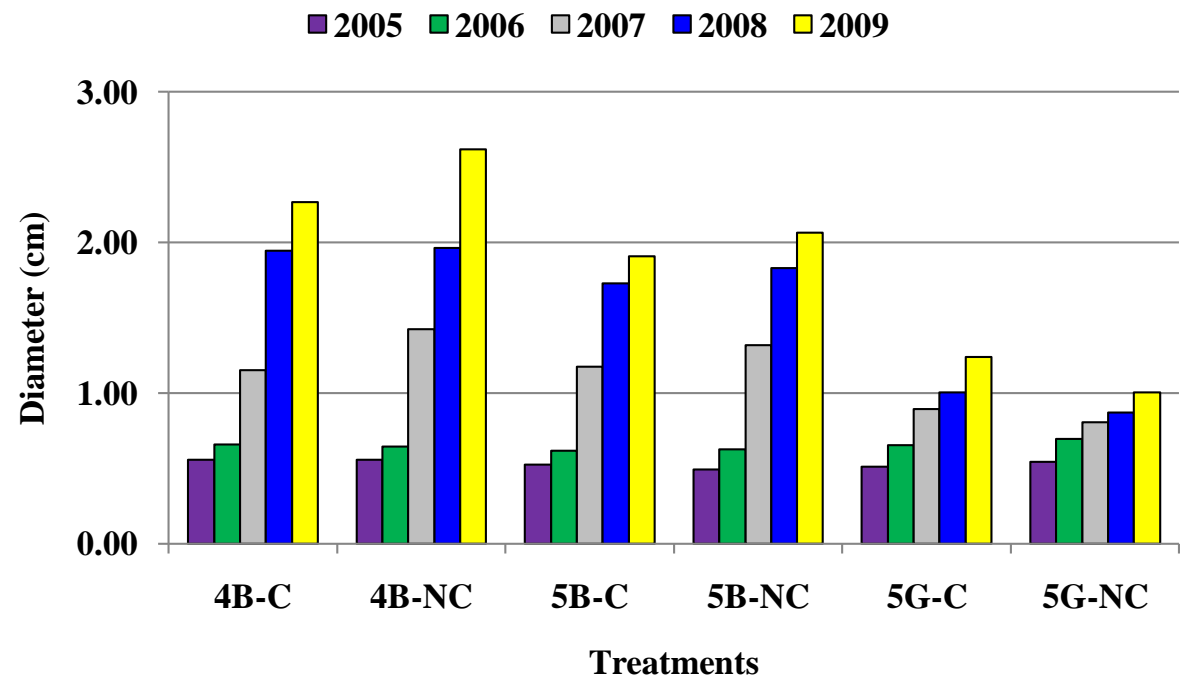

Figure 2-4c. Average diameter of oak for five growing seasons in six soil treatments at Catenary Coal's Samples mine in Kanawha County, WV.

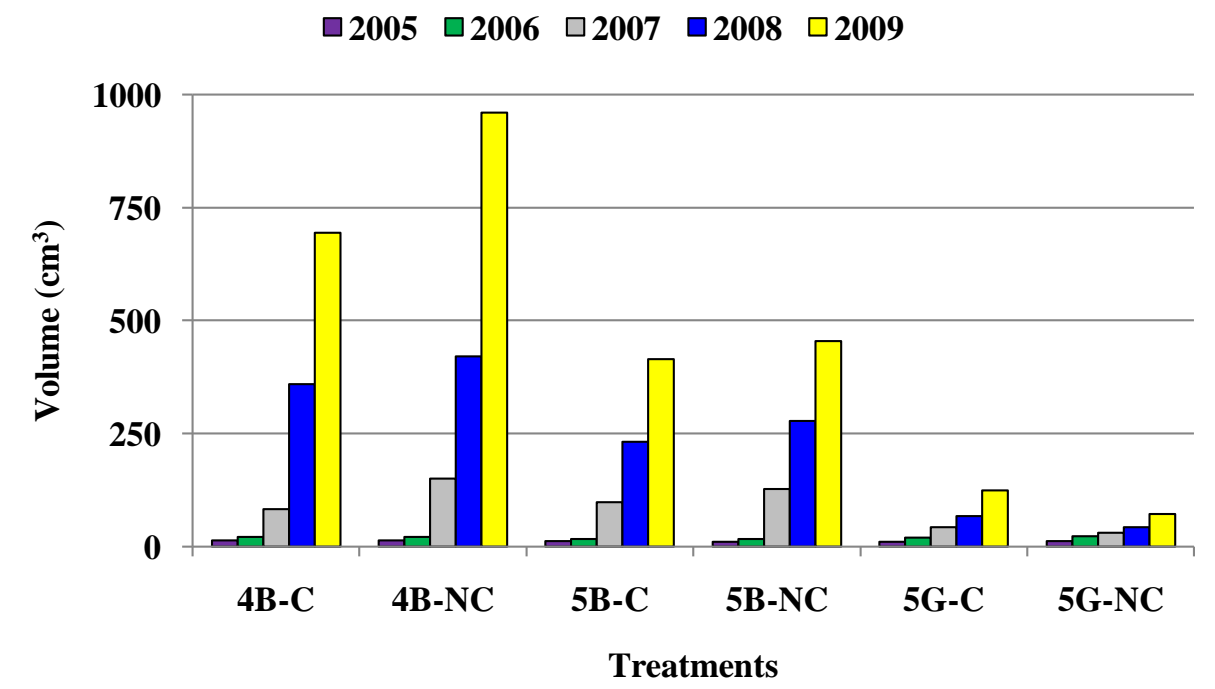

Figure 2-4d. Average volume of oak for five growing seasons in six soil treatments at Catenary Coal's Samples mine in Kanawha County, WV.

Redbud, along with the three oak species (chestnut, red, and white), had the fourth highest average survival across the six soil treatment combinations at $71 \%$ with an average volume of $453 \mathrm{~cm}^{3}$ and a good to very good vigor rating of 4.3. The highest average survival $(100 \%)$ was recorded in the $4 \mathrm{~B}-\mathrm{NC}, 5 \mathrm{~B}-\mathrm{C}$, and $5 \mathrm{G}-\mathrm{NC}$ treatments while the lowest $(0 \%)$ was recorded in the 5G-C treatment. The greatest average volume $\left(1423 \mathrm{~cm}^{3}\right)$ was recorded in the 4B-C treatment while the lowest $\left(7 \mathrm{~cm}^{3}\right)$ was recorded in the $5 \mathrm{G}-\mathrm{NC}$ treatment. The highest 
average vigor rating (5.0) was recorded in the 4B-C and 5B-C treatments while the lowest (3.6) was recorded in the 5B-NC treatment. Species survival, height, diameter, and volume for the length of the study can be seen in Figures 2-5a through 2-5d. Due to the higher $\mathrm{pH}$ found in the gray sandstone treatments, redbud performance was expected to be higher but the lower percentage of fines and thus decreased water holding capacity could indicate that moisture is a limiting factor for this species.

$\square 2006 \square 2007 \square 2009$

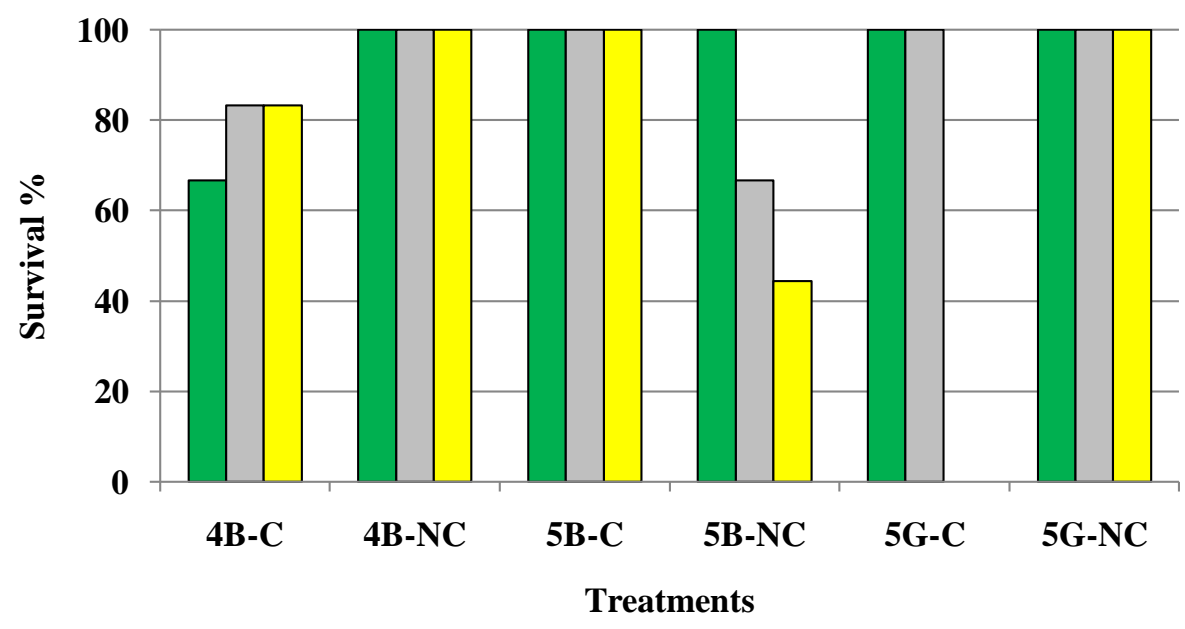

Figure 2-5a. Average survival of redbud for three growing seasons in six soil treatments at Catenary Coal's Samples mine in Kanawha County, WV

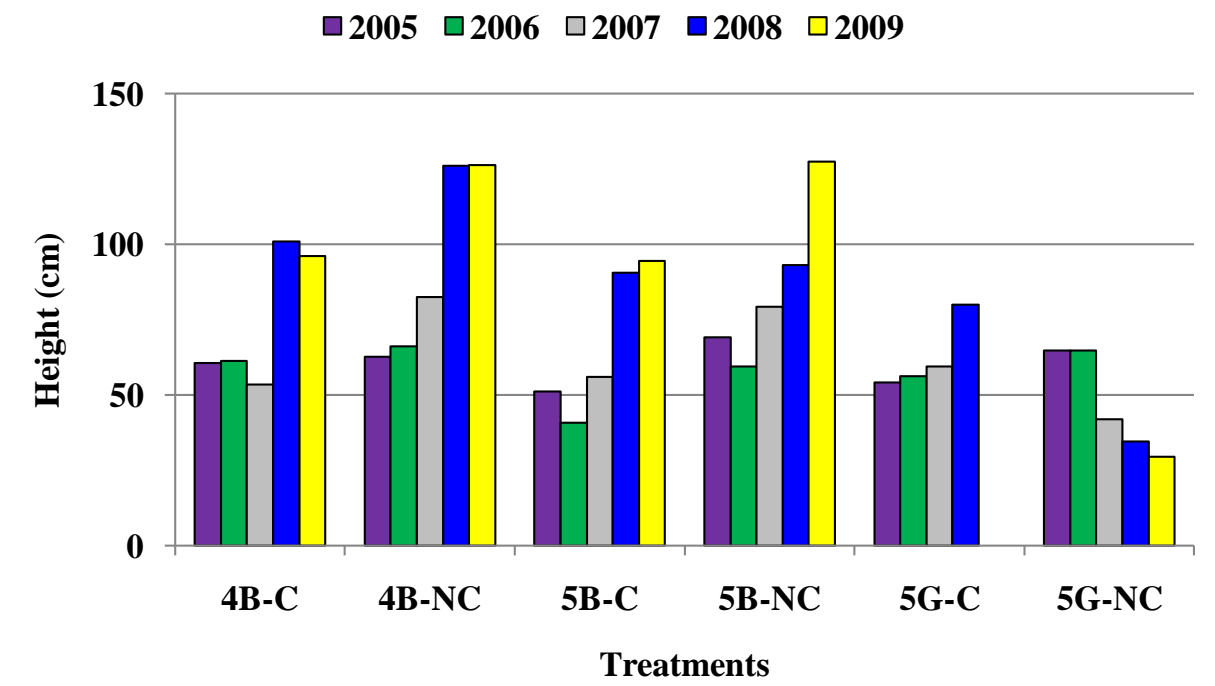

Figure 2-5b. Average height of redbud for five growing seasons in six soil treatments at Catenary Coal's Samples mine in Kanawha County, WV. 


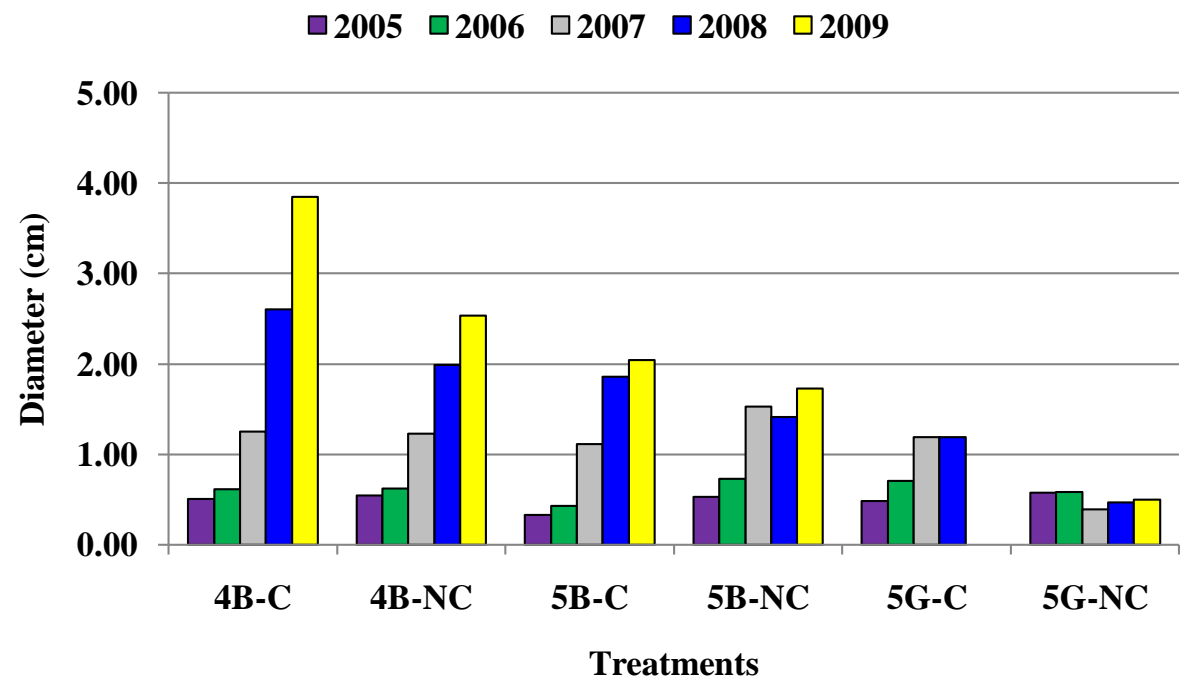

Figure 2-5c. Average diameter of redbud for five growing seasons in six soil treatments at Catenary Coal's Samples mine in Kanawha County, WV.

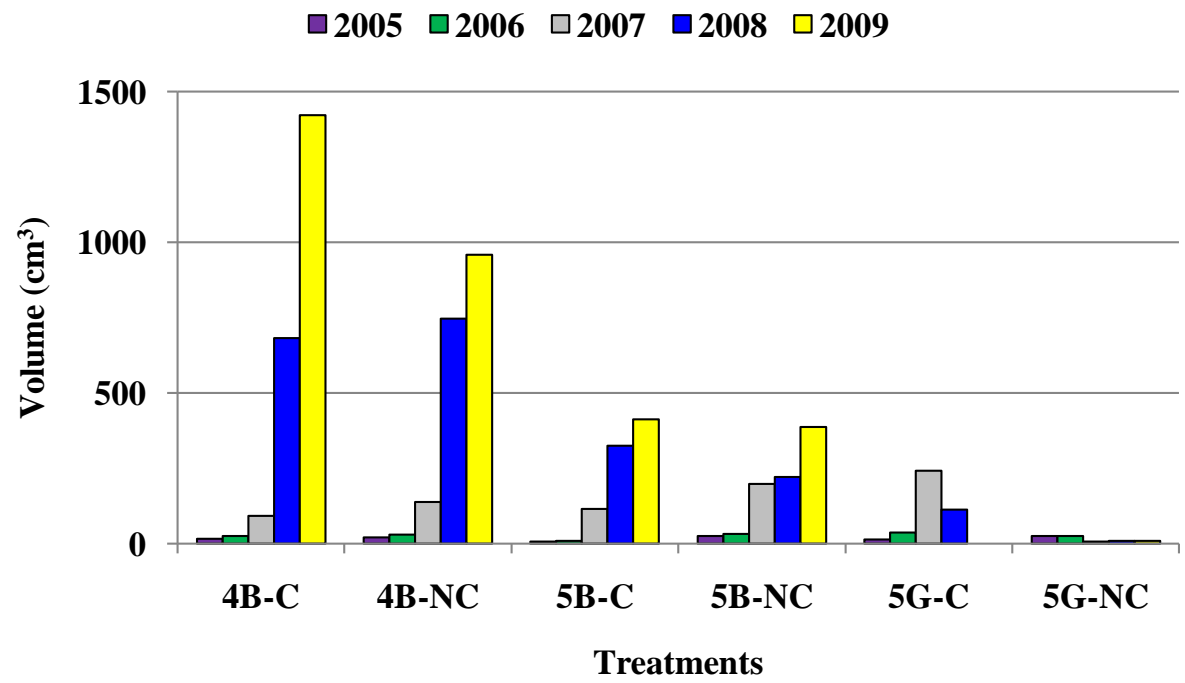

Figure 2-5d. Average volume of redbud for five growing seasons in six soil treatments at Catenary Coal's Samples mine in Kanawha County, WV.

Sugar maple had the third highest average survival across the six soil treatment combinations at $72 \%$ with an average volume of $111 \mathrm{~cm}^{3}$ and a moderate vigor rating of 3.0. The highest average survival (93\%) was recorded in the 4B-NC treatment while the lowest $(43 \%)$ was recorded in the 5B-NC treatment. The greatest average volume $\left(191 \mathrm{~cm}^{3}\right)$ was recorded in the 5B-C treatment while the lowest $\left(28 \mathrm{~cm}^{3}\right)$ was recorded in the 5G-NC treatment. The highest average vigor rating (3.6) was recorded in the 5B-C treatment while the lowest (2.6) was 
recorded in the 5G-C treatment. Species survival, height, diameter, and volume for the length of the study can be seen in Figures 2-6a through 2-6d. Sugar maple showed much greater volume in the brown sandstone plots indicating that the greater amount of fines (moist soil conditions) of the brown sandstone promoted its growth.

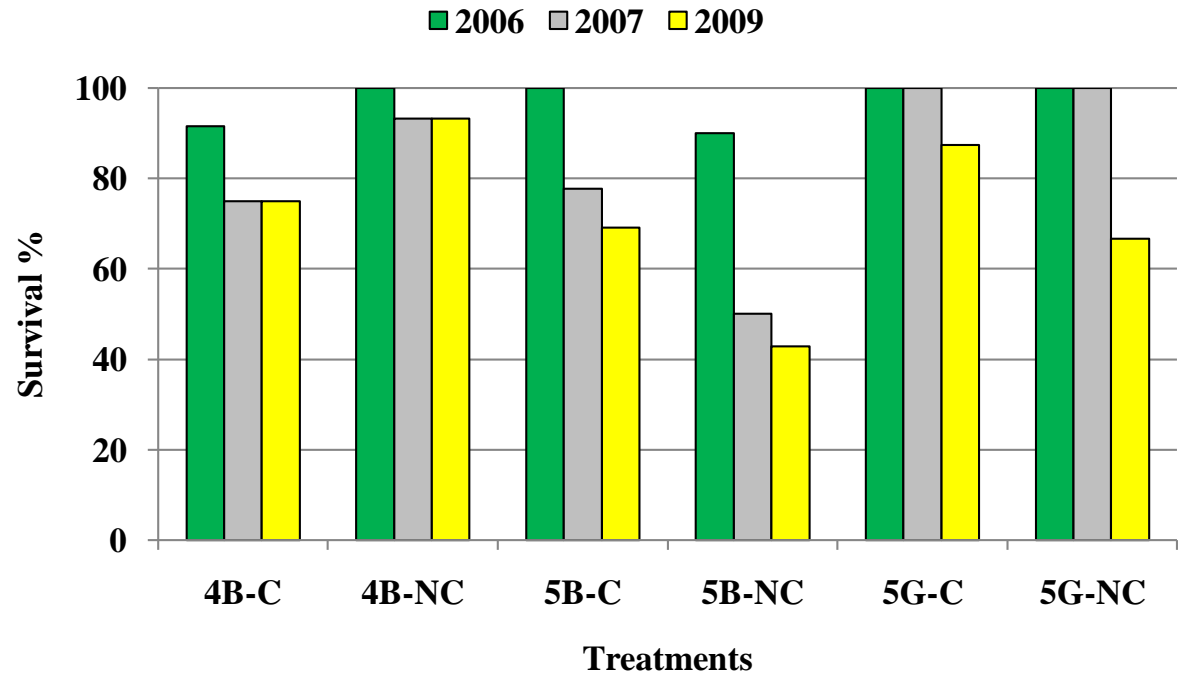

Figure 2-6a. Average survival of sugar maple for three growing seasons in six soil treatments at Catenary Coal's Samples mine in Kanawha County, WV.

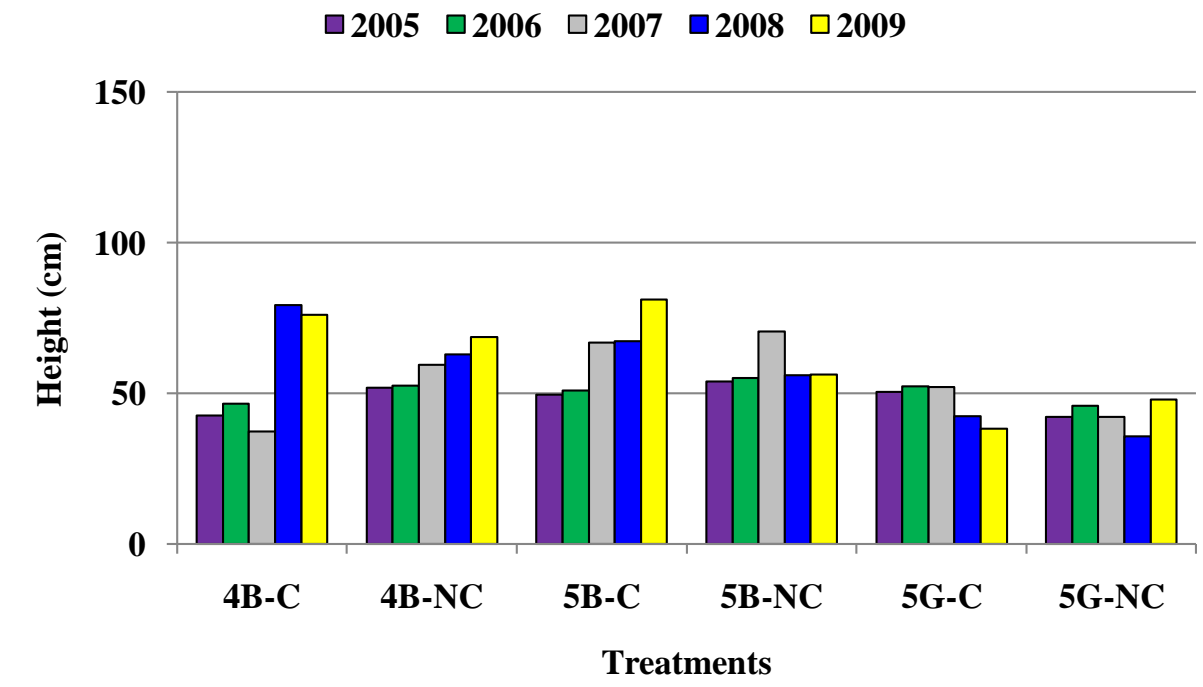

Figure 2-6b. Average height of sugar maple for five growing seasons in six soil treatments at Catenary Coal's Samples mine in Kanawha County, WV. 


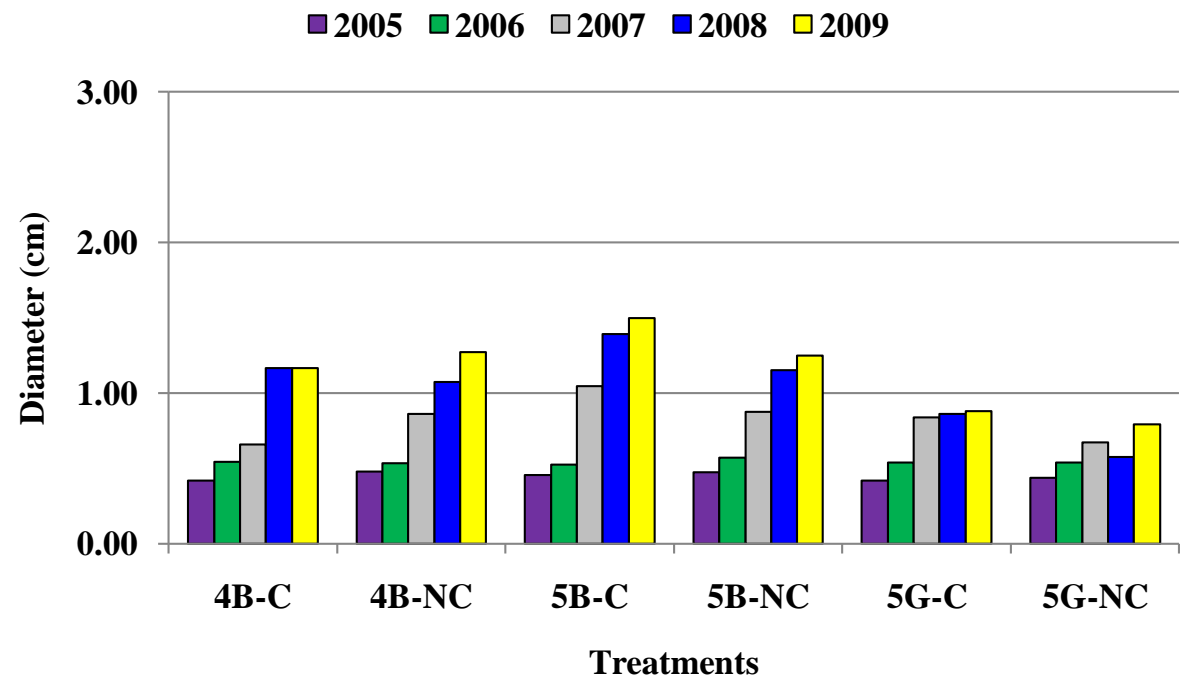

Figure 2-6c. Average diameter of sugar maple for five growing seasons in six soil treatments at Catenary Coal's Samples mine in Kanawha County, WV.

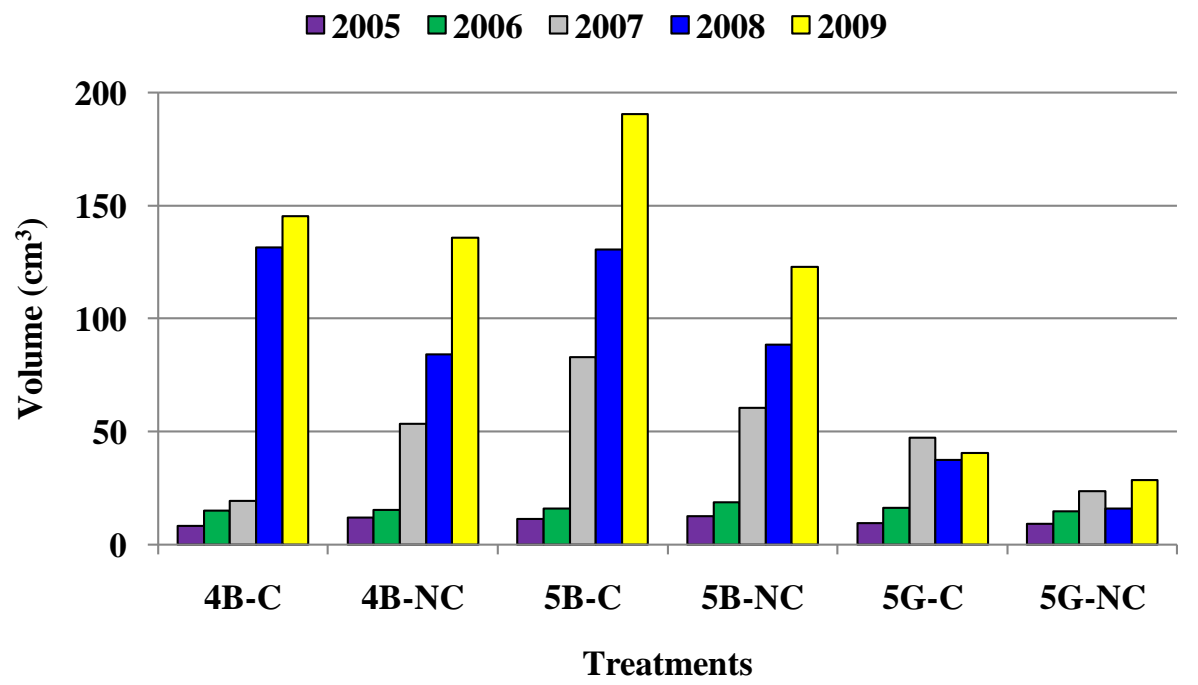

Figure 2-6d. Average volume of sugar maple for five growing seasons in six soil treatments at Catenary Coal's Samples mine in Kanawha County, WV.

Tulip poplar had the second lowest average survival across the six soil treatment combinations at $57 \%$ with an average volume of $627 \mathrm{~cm}^{3}$ and a moderate to good vigor rating of 3.7. The highest average survival (82\%) was recorded in the 5G-C treatment while the lowest $(22 \%)$ was recorded in the 4B-C treatment. The greatest average volume $\left(1129 \mathrm{~cm}^{3}\right)$ was recorded in the 4B-NC treatment while the lowest $\left(148 \mathrm{~cm}^{3}\right)$ was recorded in the $5 \mathrm{~B}-\mathrm{C}$ treatment. The highest average vigor rating (4.2) was recorded in the 5B-C treatment while the lowest (3.1) 
was recorded in the $4 \mathrm{~B}-\mathrm{C}$ treatment. Species survival, height, diameter, and volume for the length of the study can be seen in Figures 2-7a through 2-7d. Tulip poplar showed a trend of greater volume in the noncompacted plots in both brown and gray sandstone treatments suggesting this species to be more sensitive to soil compaction.

$\square 2006 \square 2007 \square 2009$

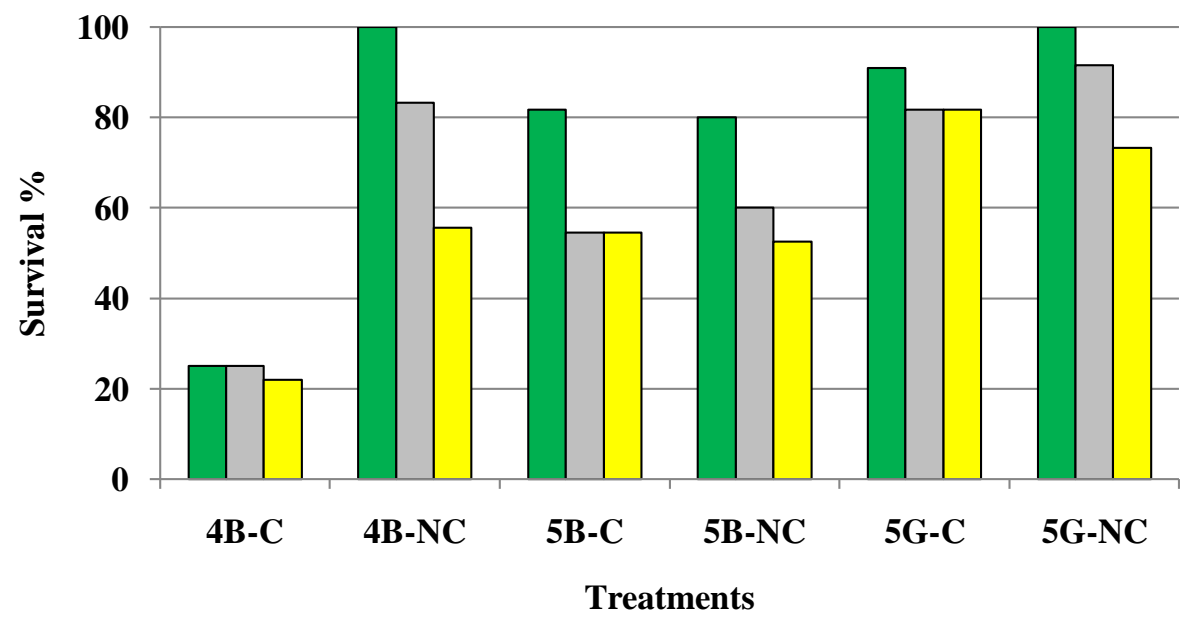

Figure 2-7a. Average survival of tulip poplar for three growing seasons in six soil treatments at Catenary Coal's Samples mine in Kanawha County, WV.

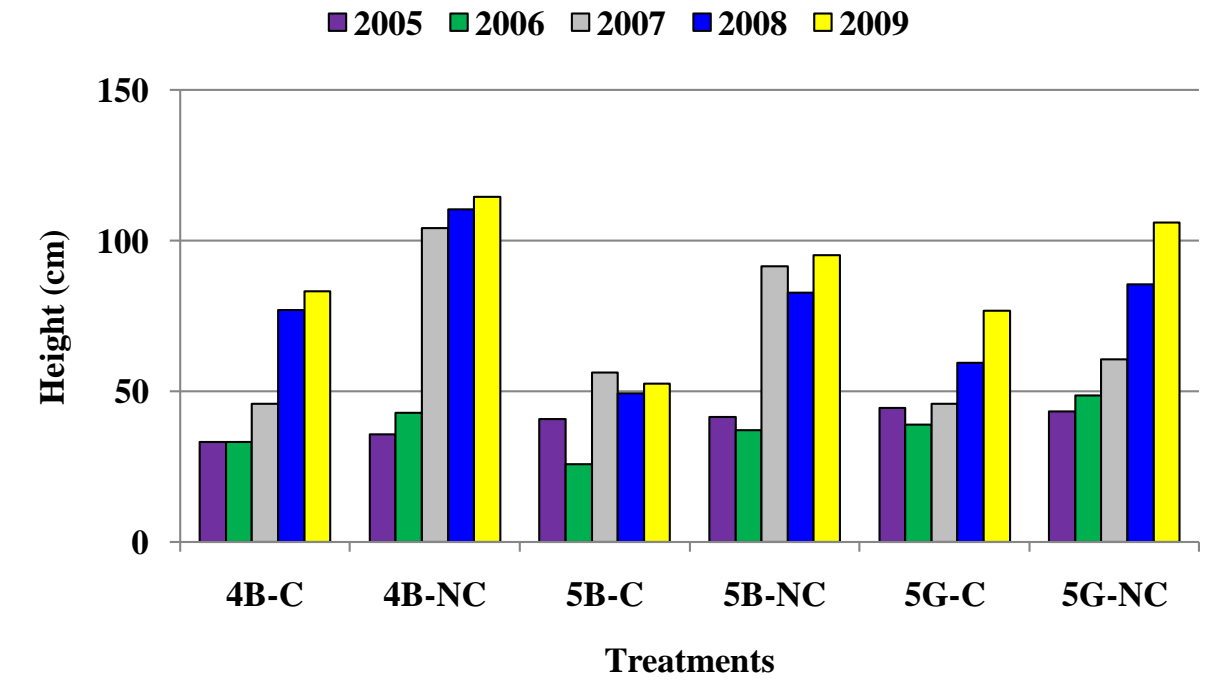

Figure 2-7b. Average height of tulip poplar for five growing seasons in six soil treatments at Catenary Coal's Samples mine in Kanawha County, WV. 


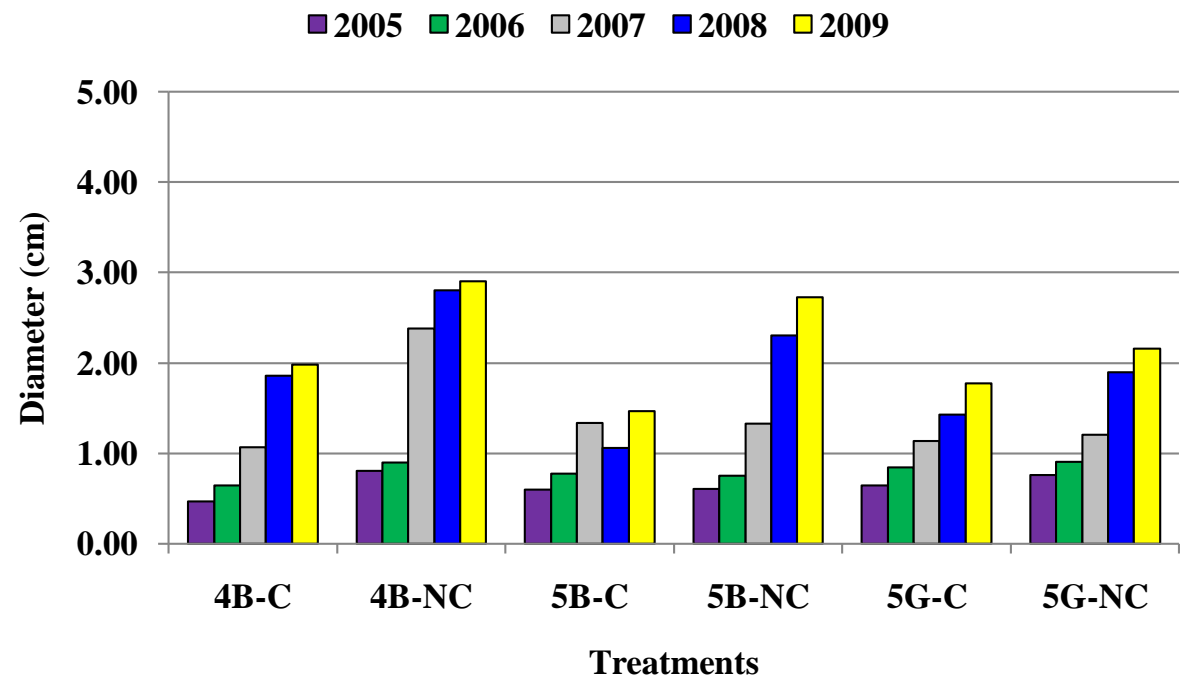

Figure 2-7c. Average diameter of tulip poplar for five growing seasons in six soil treatments at Catenary Coal's Samples mine in Kanawha County, WV.

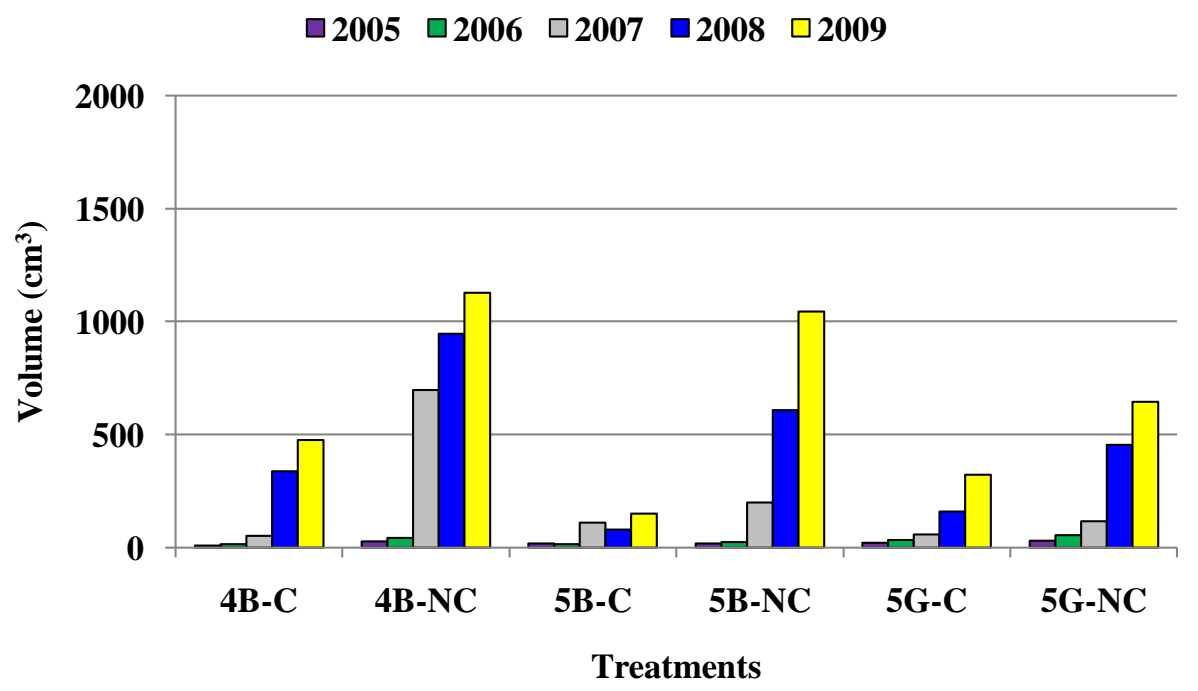

Figure 2-7d. Average volume of tulip poplar for five growing seasons in six soil treatments at Catenary Coal's Samples mine in Kanawha County, WV.

White ash had the second highest survival across the six soil treatment combinations at $76 \%$ with an average volume of $518 \mathrm{~cm}^{3}$ and a good to very good vigor rating of 4.2 . The highest average survival $(100 \%)$ was recorded in the $5 \mathrm{G}-\mathrm{C}$ treatment while the lowest $(60 \%)$ was recorded in the $5 \mathrm{~B}-\mathrm{NC}$ and $5 \mathrm{G}-\mathrm{NC}$ treatments. The greatest average volume $\left(863 \mathrm{~cm}^{3}\right)$ was recorded in the 4B-NC treatment while the lowest $\left(85 \mathrm{~cm}^{3}\right)$ was recorded in the 5G-NC 
treatment. The highest average vigor rating (4.7) was recorded in the $5 \mathrm{~B}-\mathrm{C}$ treatment while the lowest (3.8) was recorded in the 5G-NC treatment. Species survival, height, diameter, and volume for the length of the study can be seen in Figures 2-8a through 2-8d. White ash has been found to have exceptional survival and growth on mine soils by Skousen et al. (2009) and performed as well in our study with an average survival across treatments of $76 \%$.

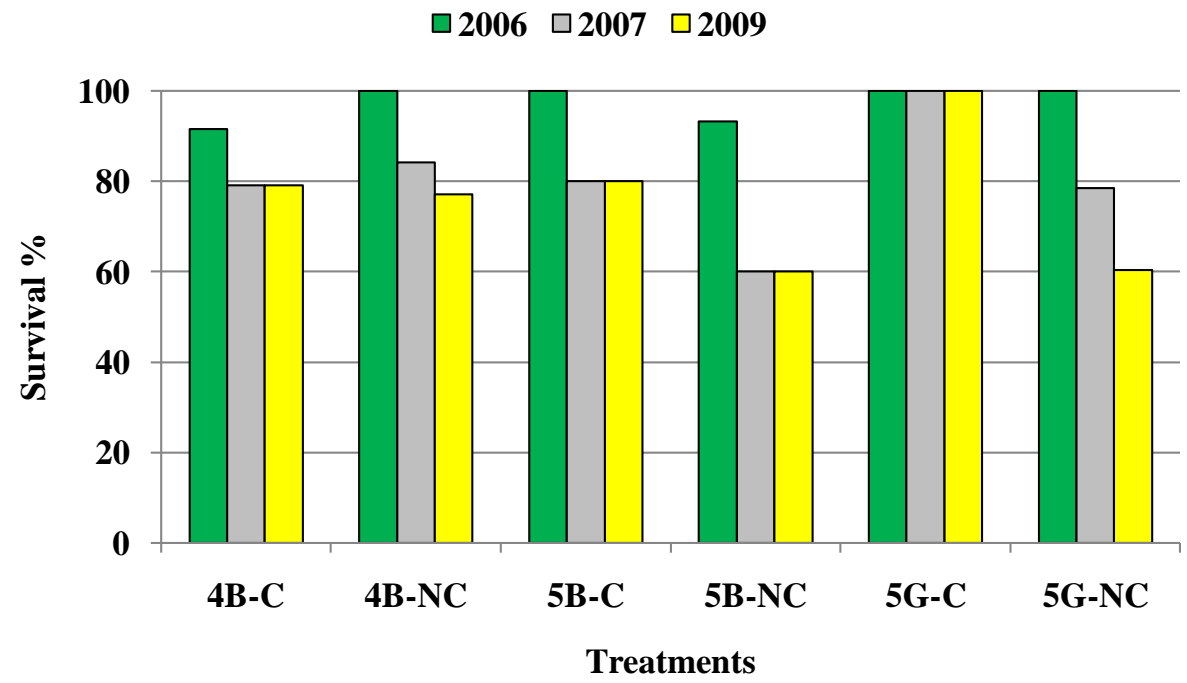

Figure 2-8a. Average survival of white ash for three growing seasons in six soil treatments at Catenary Coal's Samples mine in Kanawha County, WV.

$\square 2005 \square 2006 \square 2007 \square 2008 \square 2009$

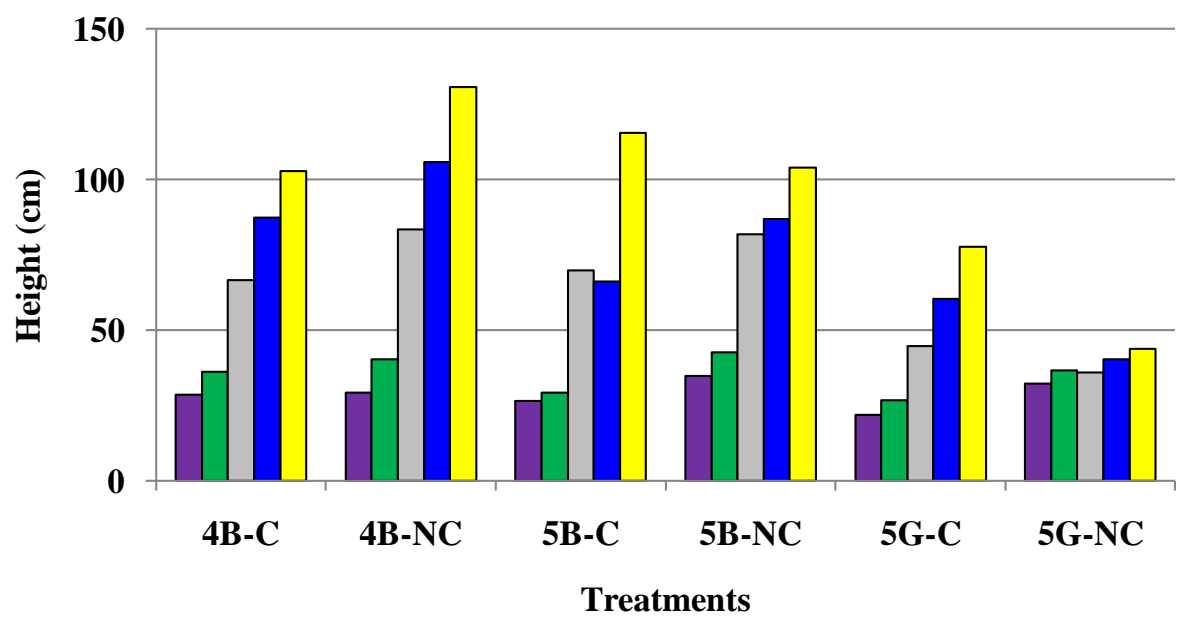

Figure 2-8b. Average height of white ash for five growing seasons in six soil treatments at Catenary Coal's Samples mine in Kanawha County, WV. 


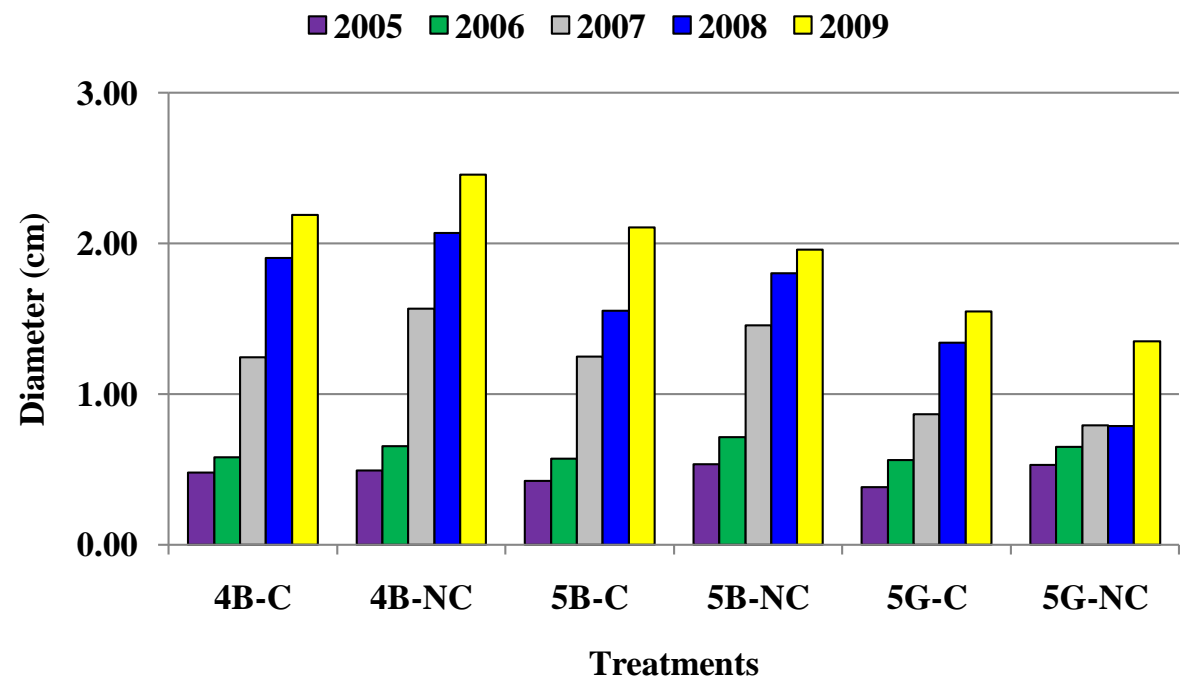

Figure 2-8c. Average diameter of white ash for five growing seasons in six soil treatments at Catenary Coal's Samples mine in Kanawha County, WV.

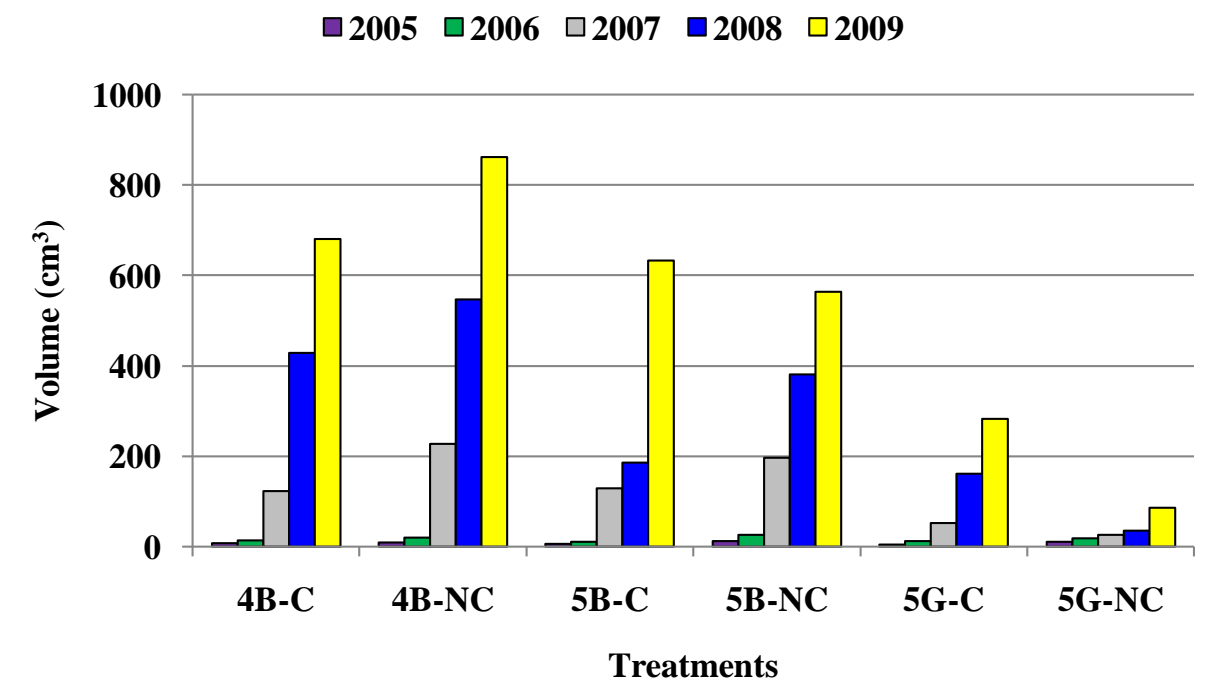

Figure 2-8d. Average volume of white ash for five growing seasons in six soil treatments at Catenary Coal's Samples mine in Kanawha County, WV.

White pine had the lowest survival across the six soil treatment combinations at $50 \%$ with an average volume of $211 \mathrm{~cm}^{3}$ and a good to very good vigor rating of 4.9. The highest average survival $(63 \%)$ was recorded in the $5 \mathrm{G}-\mathrm{C}$ treatment while the lowest $(33 \%)$ was recorded in the 5B-NC treatment. The greatest average volume $\left(560 \mathrm{~cm}^{3}\right)$ was recorded in the $4 \mathrm{~B}-\mathrm{C}$ treatment while the lowest $\left(42 \mathrm{~cm}^{3}\right)$ was recorded in the 5G-NC treatment. The highest average vigor rating (5.0) was recorded in the 4B-C, 4B-NC, 5B-C, and 5B-NC treatments while the lowest 
(4.7) was recorded in the 5G-NC treatment. Species survival, height, diameter, and volume for the length of the study can be seen in Figures 2-9a through 2-9d. White pine is particularly important in this study since this species is used as an indicator of the success of tree planting for Commercial Forestry post mining land uses. In order to meet bond release requirements, it must attain height growth increments equal to or greater than $0.46 \mathrm{~m}$ on average for four or more consecutive years. After five growing seasons, it is starting to show increases in height growth on the brown sandstone that would qualify the site for bond release (Figure 2-9b).

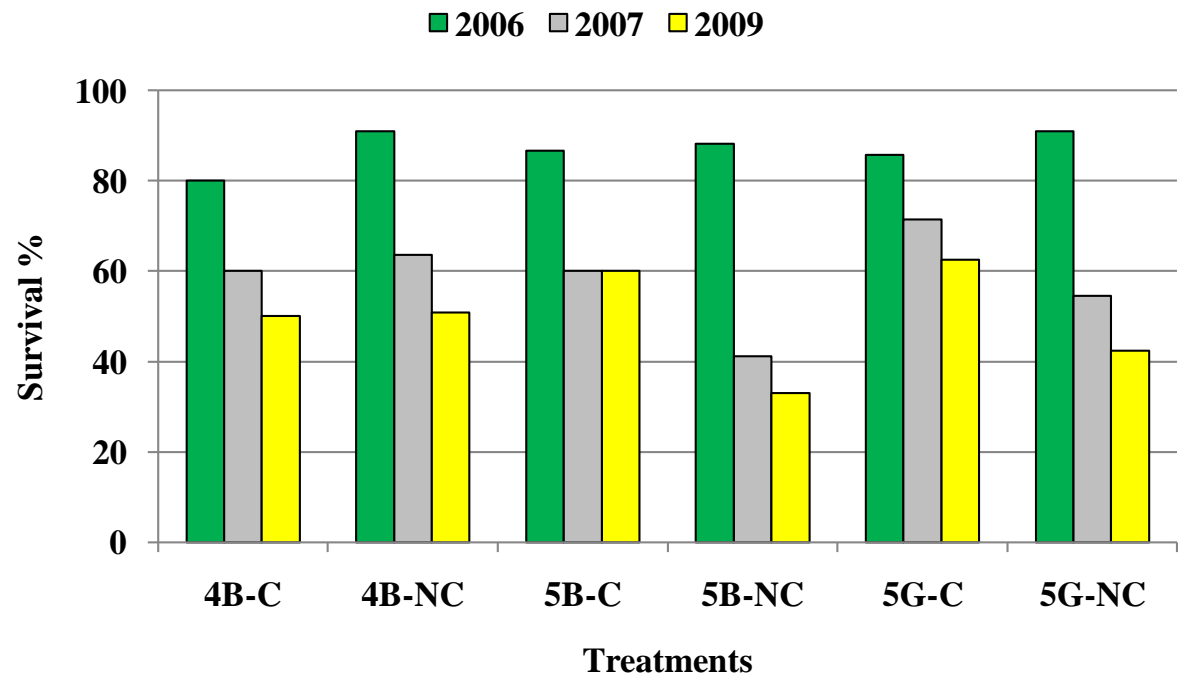

Figure 2-9a. Average survival of white pine for three growing seasons in six soil treatments at Catenary Coal's Samples mine in Kanawha County, WV. 


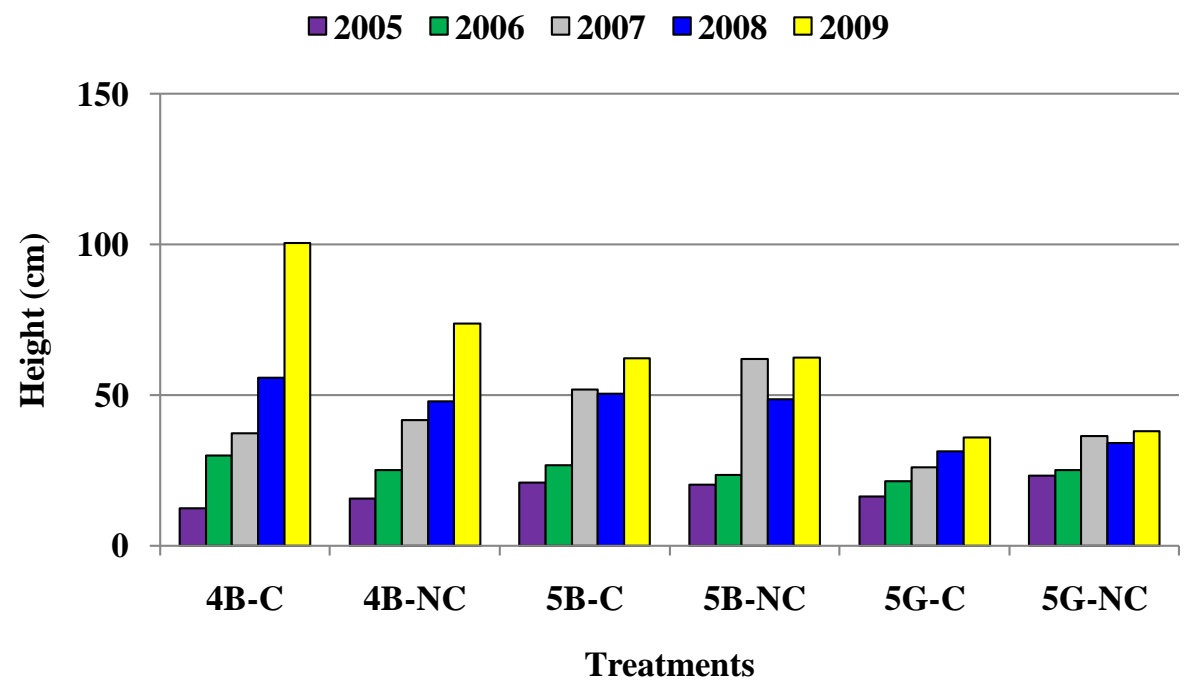

Figure 2-9b. Average height of white pine for five growing seasons in six soil treatments at Catenary Coal's Samples mine in Kanawha County, WV.

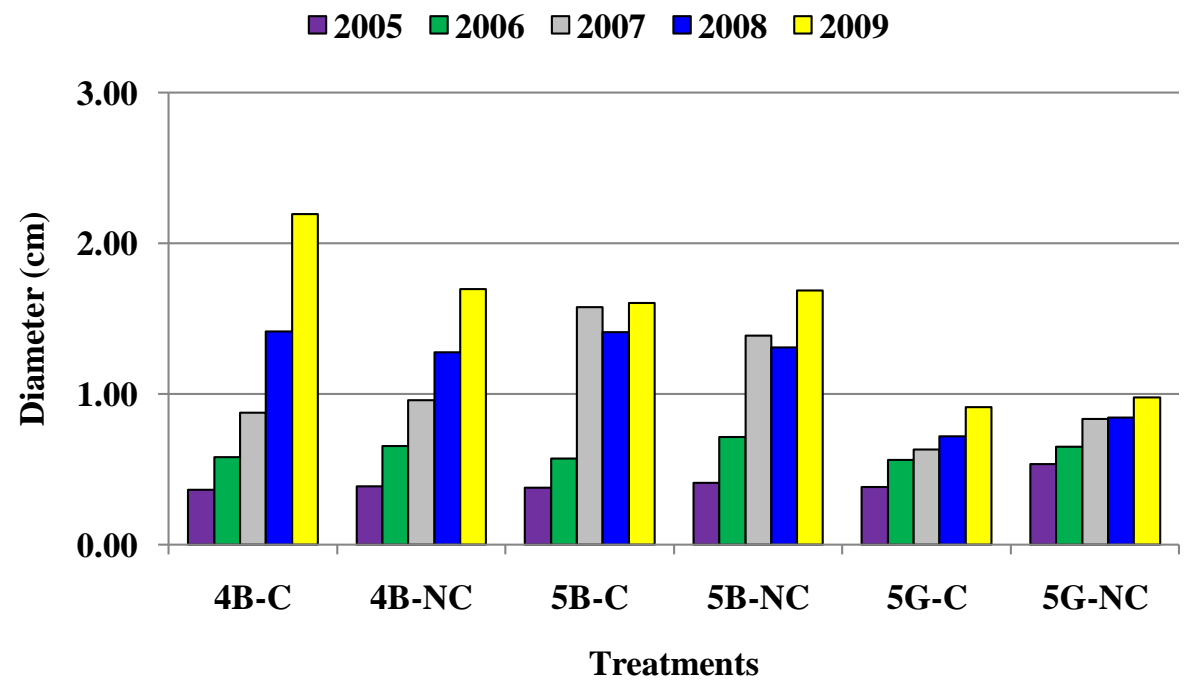

Figure 2-9c. Average diameter of white pine for five growing seasons in six soil treatments at Catenary Coal's Samples mine in Kanawha County, WV. 


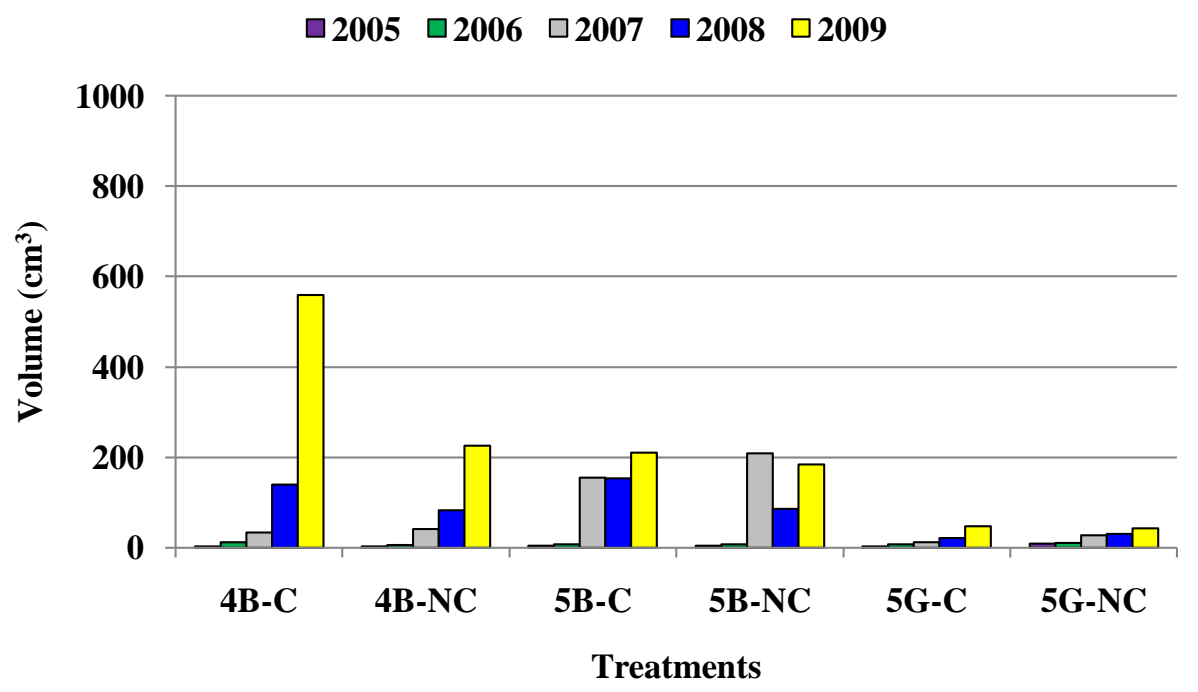

Figure 2-9d. Average volume of white pine for five growing seasons in six soil treatments at Catenary Coal's Samples mine in Kanawha County, WV.

\section{$\underline{\text { Summary and Conclusions }}$}

Few changes were found for soil properties after five years. The most notable change was found for EC which decreased significantly in all treatment combinations with the exception of the 4B-NC treatment. There were no significant changes for soil $\mathrm{pH}$ among years and after five years soil $\mathrm{pH}$ was still significantly greater for gray sandstone treatments compared to the brown sandstone. Extractable element concentrations continued to vary greatly among treatment combinations after five years. Potassium decreased significantly after five years across all treatment combinations and $\mathrm{Ca}, \mathrm{Al}, \mathrm{P}$, and Fe showed varying changes from 2005 to 2009 .

No significant differences for survival were found when comparing sandstone (brown vs. gray), compaction (compacted vs. noncompacted), and depth of substrate (1.2 m vs. $1.5 \mathrm{~m})$ across all tree species planted in this study. However, volume was significantly greater in brown sandstone vs. gray sandstone and although not significantly different volume does seem to be affected by compaction of the substrate with trees in noncompacted treatments having greater volume than those in compacted treatments. Interactions by substrate, compaction, and depth 
showed little difference for survival but showed great differences for volume between gray sandstone treatments with volumes of $165 \mathrm{~cm}^{3}$ and $191 \mathrm{~cm}^{3}$ compared to brown sandstone treatments which had volumes that ranged from $1052 \mathrm{~cm}^{3}$ to $2409 \mathrm{~cm}^{3}$. Survival of tree species was fairly uniform across trees sampled in this study and ranged from $50 \%$ for white pine to $77 \%$ for black locust. Black locust had significantly greater volume at $7361 \mathrm{~cm}^{3}$ than all over species sampled in this study. 


\section{CHAPTER 3. SUBSTRATE, HYDROSEEDING, AND BARK MULCH EFFECTS ON TREE SURVIVAL AND VOLUME ON A RECLAIMED SURFACE MINE IN WEST VIRGINIA}

\section{Objectives}

a. Determine tree growth and survival of weathered brown and unweathered gray sandstone substrates with and without treatments of herbaceous ground cover and bark mulch.

b. Assess the physical and chemical properties of mine soils three years after reclamation.

\section{Materials and Methods}

This study was conducted at ICG Eastern, LLC's Birch River surface mine $\left(38^{\circ} 2^{\prime} 43^{\prime \prime} \mathrm{N}\right.$, $81^{\circ} 30^{\prime} 29^{\prime \prime}$ W) near the town of Cowen in Webster County, West Virginia. In October 2006, ICG Eastern constructed a 2.8 ha forestry demonstration plot. The demonstration plot was constructed by end-dumping overburden material in closely adjacent piles and using one to two passes of a bulldozer to knock the tops off of the piles. One-half of the demonstration plot was constructed using weathered brown sandstone while the other half was unweathered gray sandstone. After the overburden material was placed, a 15-cm-layer of bark mulch and a hydroseeding treatment were applied to a portion of each sandstone type. Overall there were eight soil treatments including combinations of substrate, mulch, and hydroseeding (Table 3-1).

Table 3-1. Soil treatment combinations at ICG Eastern, LLC's Birch River Operation in Webster County, WV

\begin{tabular}{ll}
\hline Treatment & Abbreviation \\
\hline weathered brown sandstone & Bss \\
weathered brown sandstone w/bark mulch & BssB \\
weathered brown sandstone w/hydroseeding & BssH \\
weathered brown sandstone w/bark mulch and w/hydroseeding & BssBH \\
unweathered gray sandstone & Gss \\
unweathered gray sandstone w/bark mulch & GssB \\
unweathered gray sandstone w/hydroseeding & GssH \\
unweathered gray sandstone w/bark mulch and w/hydroseeding & GssBH \\
\hline
\end{tabular}

In Spring 2007, twelve species of trees were manually planted by a tree planting company in a semi-random fashion across the 2.8-ha demonstration plot (Table 3-2). The trees 
were planted on 2.4-m centers equaling an initial density of 1,680 trees per ha across the demonstration plot. The hydroseeding mixture was applied in September 2007 at a rate of 35.8 $\mathrm{kg} / \mathrm{ha}$ (Table 3-3).

Table 3-2. Species and number of trees planted at ICG Eastern, LLC's Birch River Operation in Webster County, WV

\begin{tabular}{lcc}
\hline Species & No. Planted & \% of trees planted \\
\hline Black cherry & 850 & 11 \\
Black locust & 800 & 10 \\
Eastern redbud & 350 & 4 \\
Gray dogwood & 350 & 4 \\
Northern red oak & 850 & 11 \\
Pitch X loblolly pine (Pinus rigida $\times$ P. taeda) & 800 & 10 \\
Sugar maple & 850 & 11 \\
Sycamore & 450 & 6 \\
Tulip poplar & 600 & 8 \\
White ash & 850 & 11 \\
White oak & 850 & 11 \\
White pine & 400 & 5 \\
Total & 8,000 & 100 \\
\hline
\end{tabular}

Table 3-3. Species and rate of ground cover hydroseeded at ICG

Eastern, LLC's Birch River Operation in Webster County, WV

\begin{tabular}{lc}
\hline Species & Rate \\
\hline & kg ha-1 \\
Birdsfoot trefoil & 11.2 \\
Kobe lespedeza (Kummerowia stipulaceea Maxim.) & 5.6 \\
Ladino clover & 3.4 \\
Orchard grass (Dactylis dglomerata L.) & 5.6 \\
Perennial ryegrass & 5.6 \\
Red top & 2.2 \\
Weeping lovegrass (Egrostis curvula Schra.) & 2.2 \\
Total & 35.8 \\
\hline
\end{tabular}

Soil, ground cover, and tree data collected were collected from within eleven 3-m wide permanent transects of varying length that were arranged in a parallel fashion across the demonstration plot. The transects were arranged in a fashion to cover at least 10 percent of each soil treatment combination within the demonstration plot (Table 3-4). 
Table 3-4. Area and transect coverage for each soil treatment combination at ICG

Eastern, LLC's Birch River Operation in Webster County, WV

\begin{tabular}{lccc}
\hline Treatment & Treatment area & Transect area & Coverage by transect \\
\hline $\mathrm{Bss}^{\dagger}$ & $\mathrm{m}^{2}$ & $\mathrm{~m}^{2}$ & $\%$ \\
$\mathrm{BssH}$ & 5,489 & 551 & 10 \\
$\mathrm{BssB}$ & 9,319 & 1,053 & 11 \\
$\mathrm{BssBH}$ & 1,650 & 197 & 12 \\
$\mathrm{Gss}$ & 1,303 & 165 & 13 \\
GssH & 5,874 & 728 & 12 \\
GssB & 2,324 & 269 & 12 \\
GssBH & 1,021 & 139 & 14 \\
Total & 648 & 80 & 12 \\
\hline
\end{tabular}

See table 3-1 for treatment descriptions

During August 2007, 2008 and 2009, trees located inside the transects were identified to species, measured for height to the highest point of live growth, and measured for diameter 2.5 $\mathrm{cm}$ above the soil surface. Volume for each tree was determined by $\mathrm{HD}^{2}$ where $\mathrm{H}=$ height and $\mathrm{D}$ = diameter. A vigor rating was also assigned to each tree sampled in 2008 and 2009. Vigor was based on a visual assessment and ranged from 1 to 5 with 1 being trees with $>75 \%$ leaves discolored and extensive dieback present and 5 being trees with $<25 \%$ leaves discolored and no visible dieback (Table 3-5).

Table 3-5. Vigor rating criteria used at ICG Eastern, LLC's Birch River Operation in Webster County, WV

\begin{tabular}{cll}
\hline Rating & Modifier & \multicolumn{1}{c}{ Vigor criteria } \\
\hline 1 & very poor & $>75 \%$ leaves discolored; extensive dieback \\
2 & poor & $50 \%-75 \%$ discoloration; dieback present \\
3 & moderate & $25-50 \%$ leaves discolored; dieback present \\
4 & good & $25-50 \%$ leaves discolored; no dieback present \\
5 & very good & $<25 \%$ leaf discolored; no dieback present \\
\hline
\end{tabular}

During August 2008 and 2009, the percentage of ground cover and ground cover composition was determined using $1-\mathrm{m}^{2}$ quadrats. Fifteen randomly placed quadrat locations were sampled within the transect boundaries for each soil treatment combination, 120 measurements total. Percent plant cover, percent litter cover and rock/bare ground were estimated within each quadrat. 
Soil samples were collected during July 2007, 2008, and 2009. Soil sampling locations were randomly selected inside the transect boundaries and four samples were taken from each soil treatment combination, 32 samples total for each year. Soil samples were collected from the top $15 \mathrm{~cm}$ with a trowel, placed in labeled bags, and transported from the field to the lab for air drying. For samples collected within bark mulch treatment combinations, the bark mulch was scraped away from the soil surface prior to excavating each sample. After each sample was air dried, it was sieved through a \#10 U.S. standard (2mm) sieve. Each sample was separated into a $<2 \mathrm{~mm}$ portion (fines) and a $>2 \mathrm{~mm}$ portion (rock fragments). Percent fines and percent rock fragments were determined on a per weight basis by dividing the weight of the individual portion by the weight of the whole soil sample. The fines portion of the soil samples were used to determine $\mathrm{pH}$, electrical conductivity, and extractable elements.

Soil $\mathrm{pH}$ was determined by mixing soil and distilled deionized water at a 1:1 ratio. Samples were mixed at 180 oscillations per minute for approximately 50 minutes. The soil $\mathrm{pH}$ was then determined using a Beckman $43 \mathrm{pH}$ meter. Electrical conductivity (EC) was used to determine the presence of soluble salts (Bower and Wilcox, 1965). Soil samples were mixed on a 2:1 ratio with distilled deionized water, mixed at 180 oscillations per minute for 15 minutes, and then allowed to equilibrate over night. After equilibrating, samples were measured with a handheld Milwaukee C65 EC Meter. A Mehlich 1 solution composed of $0.05 \mathrm{~N} \mathrm{HCl}$ and $0.025 \mathrm{~N}$ $\mathrm{H}_{2} \mathrm{SO}_{4}$ was used to obtain the extractable elements found in the soil (Mehlich, 1953). The leachate from each sample was analyzed for aluminum, barium, calcium, iron, magnesium, manganese, phosphorus, potassium, and zinc using a Perkin Elmer Plasma 400 emission spectrometer.

Soil data were analyzed by General Linear Model to compare soil properties ( $\mathrm{pH}$, fines, 
rock fragments, and EC) and extractable elements (Mg, K, Ca, AL, P, Mn, Fe, and $\mathrm{Zn})$ by year and soil treatment combination. Tukey's multiple comparison test was used to determine significant differences at $\mathrm{P}<0.05$ level. Few significant differences were observed for soil properties and extractable elements within soil treatment combination by year. Thus, soil data from 2007 through 2009 are presented but significant differences are only indicated on means across the three years of data.

Ground cover data were analyzed by one-way ANOVA to compare cover types (herbaceous, bark/litter, tree, bare ground/rock, and total cover) by soil treatment combination for 2009. Tukey's multiple comparison test was used to determine significant differences at $\mathrm{P}$ $<0.05$ level.

Due to unequal sample numbers, Proc GLM was used to analyze the tree data and significant differences were determined at the $\mathrm{P}<0.10$ level. Only selected populations of trees were used in the statistical analysis where sample numbers were adequate for analyses. Species of trees with $<2$ trees represented in a treatment combination were not included in the statistical analysis. Also due to low sample numbers, interactions among treatment combinations for each species were not determined.

\section{$\underline{\text { Results and Discussion }}$}

$\underline{\text { Soil }}$

The brown sandstone alone and brown sandstone with hydroseeding treatment combinations had significantly lower $\mathrm{pH}$ values (4.6 and 4.9) across the three years while no significant difference was found among the other six treatment combinations, which varied between $\mathrm{pH} 7.7$ to 8.2 (Table 3-6). After three years, $\mathrm{pH}$ values showed a decreasing trend in all treatment combinations with the exception of brown sandstone alone ( $\mathrm{pH} 4.4$ increased to 4.8) 
and brown sandstone with hydroseeding ( $\mathrm{pH} 4.5$ increased to 5.4) and gray sandstone with hydroseeding which was the same as sampled in 2007 (pH 7.7). Decreased $\mathrm{pH}$ was found for the remaining treatment combinations ranging from 0.2 to 0.8 units. The $\mathrm{pH}$ values for the brown and gray sandstone substrates were similar to Emerson et al. (2009) who found mean pH values of 4.8 to 6.1 in brown sandstone and 8.1 and 8.2 in gray sandstone substrates across three years. The trend of decreasing $\mathrm{pH}$ was also similar to Haering et al. (1993) in which $\mathrm{pH}$ values decreased over the first three years of the study. Haering et al. (1993) also found that after the first three years the $\mathrm{pH}$ level rebounded to near initial levels due to continued carbonate weathering and exposure to additional climatic factors.

The greater amount of fines found in the brown sandstone alone was expected due to the presence of native topsoil and increased weathering of the brown sandstone substrates before being placed at the surface during reclamation. As so, these results were similar to Emerson et al. (2009) who found the percentage of fines to be 49 to $53 \%$ in brown sandstone substrates and $34 \%$ in gray sandstone after a three year period. Haering et al. (2004) also found that weathered brown sandstone substrates had a greater percentage of fines than unweathered gray sandstone when comparing pre- and post-SMCRA mines sites in southwestern Virginia. Both brown and gray sandstone substrates are expected to weather rapidly after being placed on the surface. However, a freeze-thaw study conducted by Angel et al. (2008) found that brown sandstone samples lost $64 \%$ of its mass compared to $35 \%$ for gray sandstone. This demonstrates that as these materials continue to weather, further increases in fine material are expected but could occur at significantly different rates.

The treatment combinations with bark mulch had significantly greater EC values ( 0.40 to $\left.0.47 \mathrm{dS} \mathrm{m}^{-1}\right)$ than treatment combinations that did not receive a bark mulch application $(0.11$ to 
$0.16 \mathrm{dS} \mathrm{m}^{-1}$ ) (Table 3-6). Overall the mean EC values across the eight treatment combinations ranged from 0.11 to $0.47 \mathrm{dS} \mathrm{m}^{-1}$. After three years, five of the eight treatment combinations showed a decrease in EC from 2007 to 2008 as well as 2008 to 2009. Three combinations (brown sandstone with bark mulch, brown sandstone with hydroseeding, and gray sandstone with bark mulch) showed a slight increase from 2008 to 2009. Decreases from 2007 to 2009 across the eight treatment combinations ranged from 0.11 to $0.44 \mathrm{dS} \mathrm{m}^{-1}$. All EC values were less than 1.0 $\mathrm{dS} \mathrm{m} \mathrm{m}^{-1}$, which is considered acceptable for trees since EC values of $2.0 \mathrm{dS} \mathrm{m}^{-1}$ are thought to be marginally detrimental and values $>3.0 \mathrm{dS} \mathrm{m}^{-1}$ are considered toxic for plants on mined lands (Cummins et al., 1965).

Table 3-6. 2007-2009 soil properties in eight soil treatment combinations at ICG Eastern, LLC's Birch River Operation in Webster County, WV

\begin{tabular}{ccccccccc}
\hline & \multicolumn{7}{c}{ Treatments ${ }^{\dagger}$} \\
\cline { 2 - 8 } Properties & Bss & BssB & BssH & BssBH & Gss & GssB & GssH & GssBH \\
\hline pH & & & & & & & & \\
2007 & 4.4 & 7.8 & 4.5 & 7.9 & 8.2 & 7.8 & 7.7 & 7.8 \\
2008 & 4.7 & 7.1 & 4.8 & 8.1 & 7.9 & 7.0 & 7.4 & 6.9 \\
Avg. & $4.6^{\mathrm{c}+}$ & 7.5 & 5.4 & 7.7 & 7.8 & 7.5 & 7.7 & 7.0 \\
Percent fines & & $4.9^{\mathrm{c}}$ & $7.9^{\mathrm{ab}}$ & $8.0^{\mathrm{a}}$ & $7.4^{\mathrm{ab}}$ & $7.6^{\mathrm{ab}}$ & $7.2^{\mathrm{b}}$ \\
2007 & 42 & 35 & 42 & 41 & 28 & 28 & 26 & 49 \\
2008 & 57 & 24 & 47 & 27 & 42 & 34 & 34 & 32 \\
2009 & 52 & 37 & 49 & 41 & 40 & 42 & 36 & 35 \\
Avg. & $51^{\mathrm{a}}$ & $33^{\mathrm{c}}$ & $46^{\mathrm{ab}}$ & $36^{\mathrm{bc}}$ & $37^{\mathrm{bc}}$ & $35^{\mathrm{bc}}$ & $32^{\mathrm{c}}$ & $39^{\mathrm{bc}}$ \\
Percent rock & & & & & & & & \\
2007 & 58 & 65 & 58 & 59 & 72 & 72 & 74 & 51 \\
2008 & 43 & 76 & 53 & 73 & 58 & 66 & 66 & 68 \\
2009 & 48 & 63 & 51 & 59 & 60 & 58 & 64 & 65 \\
Avg. & $49^{\mathrm{c}}$ & $68^{\mathrm{a}}$ & $54^{\mathrm{bc}}$ & $64^{\mathrm{ab}}$ & $63^{\mathrm{ab}}$ & $65^{\mathrm{ab}}$ & $68^{\mathrm{a}}$ & $62^{\mathrm{ab}}$ \\
Electrical conductivity & $\mathrm{dS} \mathrm{m}^{-1}$ & & & & & & \\
2007 & 0.16 & 0.61 & 0.34 & 0.70 & 0.12 & 0.57 & 0.22 & 0.73 \\
2008 & 0.12 & 0.28 & 0.06 & 0.39 & 0.11 & 0.28 & 0.12 & 0.40 \\
2009 & 0.05 & 0.31 & 0.07 & 0.30 & 0.08 & 0.33 & 0.11 & 0.29 \\
Avg. & $0.11^{\mathrm{b}}$ & $0.41^{\mathrm{a}}$ & $0.16^{\mathrm{b}}$ & $0.47^{\mathrm{a}}$ & $0.11^{\mathrm{b}}$ & $0.40^{\mathrm{a}}$ & $0.15^{\mathrm{b}}$ & $0.47^{\mathrm{a}}$ \\
\hline
\end{tabular}

\footnotetext{
${ }^{\dagger}$ See table 3-1 for treatment descriptions

${ }^{\ddagger}$ means for each property across treatments with the same letter are not significantly different at $P<0.05$
} 
Concentrations of extractable elements varied across treatment combinations and some significant differences were found. Treatments that received an application of bark mulch (with bark mulch; with bark mulch and hydroseeding) had higher concentrations of $\mathrm{Ca}, \mathrm{K}, \mathrm{Mg}$, and $\mathrm{Mn}$ and had lower concentrations of $\mathrm{P}$ and $\mathrm{Zn}$ (Table 3-7). This suggests that bark mulch is adding nutrients to the sandstone substrates for a few elements but the mulch could also be adsorbing elements like $\mathrm{P}$ and $\mathrm{Zn}$ and decreasing their availability. Both $\mathrm{P}$ and $\mathrm{Zn}$ have a high affinity for binding to organic matter in soils (Havlin et al., 2005). Extractable P concentrations were significantly higher in gray sandstone alone and gray sandstone with hydroseeding treatment combinations when compared to brown sandstone treatments. This finding is similar to Emerson et al. (2009) who found P concentrations to be almost four times higher in gray vs. brown sandstone substrates. However, a subsequent study by Skousen and Emerson (2010) showed that the Mehlich I extractable P may not be plant available since it was not found in greater abundance in sequential extractions experiments, and therefore the higher $\mathrm{P}$ concentrations in gray sandstone do not translate into higher soluble soil $\mathrm{P}$ concentrations. Most extractable elements showed no change or slightly decreasing trends in concentration from 2007 to 2009 . Both $\mathrm{Al}$ and $\mathrm{Fe}$ had considerable increases in concentration for brown and gray sandstone substrates from 2007 to 2008 and then returned to near initial levels in 2009. Manganese was found to be similar to $\mathrm{Al}$ and $\mathrm{Fe}$ but the considerable increases were only found in the gray sandstone treatment combinations. 
Table 3-7. 2007-2009 Elemental concentrations in eight soil treatment combinations at ICG Eastern, LLC's Birch River Operation in Webster County, WV

\begin{tabular}{|c|c|c|c|c|c|c|c|c|c|}
\hline \multirow[b]{2}{*}{ Element } & \multirow[b]{2}{*}{ Year } & \multicolumn{7}{|c|}{ Treatments $\uparrow$} & \multirow[b]{2}{*}{ GssBH } \\
\hline & & Bss & BssB & BssH & BssBH & Gss & GssB & GssH & \\
\hline & & & & & $\mathrm{cmol}_{\mathrm{c}} \mathrm{kg}$ & & -- & & ----- \\
\hline \multirow{4}{*}{$\mathrm{Mg}$} & 2007 & 1.4 & 2.6 & 0.9 & 2.5 & 1.0 & 3.2 & 1.2 & 1.8 \\
\hline & 2008 & 1.5 & 1.5 & 0.5 & 2.9 & 1.2 & 3.8 & 2.0 & 4.9 \\
\hline & 2009 & 0.7 & 2.6 & 0.8 & 2.5 & 1.0 & 2.4 & 1.0 & 1.9 \\
\hline & Avg. & $1.2^{\mathrm{bc} \ddagger}$ & $2.1^{\mathrm{ab}}$ & $0.7^{\mathrm{c}}$ & $2.6^{\mathrm{a}}$ & $1.0^{\mathrm{bc}}$ & $2.8^{\mathrm{a}}$ & $1.4^{\mathrm{bc}}$ & $2.9^{\mathrm{a}}$ \\
\hline \multirow[t]{4}{*}{ K } & 2007 & 0.18 & 0.29 & 0.14 & 0.33 & 0.12 & 0.24 & 0.17 & 0.23 \\
\hline & 2008 & 0.13 & 0.18 & 0.15 & 0.28 & 0.14 & 0.20 & 0.18 & 0.28 \\
\hline & 2009 & 0.07 & 0.13 & 0.09 & 0.13 & 0.06 & 0.11 & 0.08 & 0.12 \\
\hline & Avg. & $0.13^{\mathrm{c}}$ & $0.20^{\mathrm{abc}}$ & $0.13^{\mathrm{c}}$ & $0.25^{\mathrm{a}}$ & $0.11^{\mathrm{c}}$ & $0.18^{b c}$ & $0.14^{b c}$ & $0.21^{\mathrm{ab}}$ \\
\hline \multirow[t]{5}{*}{$\mathrm{Ca}$} & 2007 & 1.4 & 28.1 & 0.8 & 27.6 & 2.2 & 26.8 & 1.8 & 23.4 \\
\hline & 2008 & 1.1 & 5.1 & 0.4 & 16.3 & 1.5 & 11.4 & 2.6 & 18.3 \\
\hline & 2009 & 0.7 & 18.9 & 1.1 & 18.2 & 1.5 & 20.7 & 1.7 & 15.3 \\
\hline & Avg. & $1.1^{\mathrm{b}}$ & $16.9^{\mathrm{a}}$ & $0.8^{\mathrm{b}}$ & $20.7^{\mathrm{a}}$ & $1.8^{\mathrm{b}}$ & $18.7^{\mathrm{a}}$ & $2.0^{\mathrm{b}}$ & $19.0^{\mathrm{a}}$ \\
\hline & & & & & -mg k & & & & \\
\hline \multirow[t]{4}{*}{$\mathrm{Al}$} & 2007 & 55 & 2 & 205 & 5 & 22 & 20 & 23 & 4 \\
\hline & 2008 & 150 & 83 & 437 & 3 & 36 & 130 & 135 & 573 \\
\hline & 2009 & 36 & 48 & 170 & 29 & 17 & 41 & 17 & 145 \\
\hline & Avg. & $80^{\mathrm{b}}$ & $44^{\mathrm{b}}$ & $271^{\mathrm{a}}$ & $12^{\mathrm{b}}$ & $25^{\mathrm{b}}$ & $64^{\mathrm{b}}$ & $58^{\mathrm{b}}$ & $241^{\mathrm{a}}$ \\
\hline \multirow[t]{4}{*}{$\mathrm{P}$} & 2007 & 12 & 1 & 7 & 2 & 12 & 2 & 22 & 3 \\
\hline & 2008 & 4 & 6 & 3 & 1 & 19 & 8 & 20 & 2 \\
\hline & 2009 & 3 & 3 & 13 & 6 & 28 & 4 & 40 & 2 \\
\hline & Avg. & $7^{\mathrm{b}}$ & $4^{b}$ & $7^{\mathrm{b}}$ & $3^{b}$ & $20^{\mathrm{a}}$ & $4^{b}$ & $28^{\mathrm{a}}$ & $2^{b}$ \\
\hline \multirow[t]{4}{*}{$\mathrm{Mn}$} & 2007 & 30 & 47 & 47 & 45 & 39 & 64 & 43 & 35 \\
\hline & 2008 & 29 & 43 & 34 & 55 & 67 & 118 & 102 & 175 \\
\hline & 2009 & 16 & 62 & 34 & 68 & 43 & 55 & 39 & 64 \\
\hline & Avg. & $25^{\mathrm{d}}$ & $51^{\mathrm{c}}$ & $38^{\mathrm{cd}}$ & $56^{\mathrm{bc}}$ & $50^{\mathrm{c}}$ & $79^{\mathrm{ab}}$ & $61^{\mathrm{bc}}$ & $91^{\mathrm{a}}$ \\
\hline \multirow[t]{4}{*}{$\mathrm{Fe}$} & 2007 & 89 & 1 & 87 & 2 & 141 & 8 & 119 & 1 \\
\hline & 2008 & 77 & 63 & 99 & 7 & 322 & 207 & 654 & 91 \\
\hline & 2009 & 18 & 16 & 52 & 28 & 75 & 13 & 72 & 37 \\
\hline & Avg. & $61^{c}$ & $27^{\mathrm{c}}$ & $79^{c}$ & $13^{c}$ & $179^{\mathrm{b}}$ & $76^{c}$ & $282^{\mathrm{a}}$ & $43^{c}$ \\
\hline \multirow[t]{4}{*}{$\mathrm{Zn}$} & 2007 & 16.6 & 0.7 & 4.4 & 0.5 & 4.9 & 1.8 & 5.1 & 0.5 \\
\hline & 2008 & 4.1 & 6.7 & 3.1 & 1.8 & 5.2 & 5.7 & 6.0 & 2.0 \\
\hline & 2009 & 4.5 & 2.7 & 4.7 & 2.9 & 4.2 & 3.5 & 4.6 & 2.4 \\
\hline & Avg. & $8.4^{\mathrm{a}}$ & $3.3^{\mathrm{bcd}}$ & $4.1^{\mathrm{bcd}}$ & $1.8^{\mathrm{cd}}$ & $4.8^{\mathrm{b}}$ & $3.7^{\mathrm{bcd}}$ & $5.2^{\mathrm{b}}$ & $1.7^{\mathrm{d}}$ \\
\hline
\end{tabular}

\footnotetext{
See table 3-1 for treatment descriptions

${ }^{\ddagger}$ means for each element across treatments with the same letter are not significantly different at $P<0.05$
}

Ground cover

The gray sandstone with bark mulch and with hydroseeding treatment combination had significantly greater herbaceous ground cover at $34 \%$ while the remaining treatment combinations ranged from 0 to $19 \%$ (Table 3-8). The greater amount of herbaceous ground cover 
could be attributed to the higher $\mathrm{pH}$ of the gray sandstone material, which is more favorable for herbaceous plants, and the added moisture that could be retained by the bark mulch. The bark mulch or litter was significantly greater in the brown and gray sandstone with bark mulch treatment combinations ( 81 and $82 \%$ ) compared to the brown and gray sandstone with bark mulch and with hydroseeding (58 and 51\%), while the brown and gray sandstone alone were significantly lower. The brown and gray sandstone with bark mulch and with hydroseeding had lower amounts of bark or litter recorded due to the herbaceous cover that was also recorded in those treatment combinations. No significant differences were found for the percentage of tree cover ( 1 to $4 \%$ ) across the eight treatment combinations. Total ground cover was significantly greater on brown and gray substrates that had bark mulch and bark mulch and hydroseeding applications and ranged from 78 to $88 \%$, while treatment combinations of brown and gray sandstone alone and brown and gray sandstone with hydroseeding ranged from 1 to $16 \%$. Results for the percentage of bare ground or rock were exact opposites of the total cover found in each treatment combination.

Table 3-8. Ground cover on eight soil treatment combinations at ICG Eastern, LLC's Birch River Operation in Webster County, WV

\begin{tabular}{|c|c|c|c|c|c|c|c|c|c|}
\hline \multirow[b]{2}{*}{ Cover } & \multicolumn{8}{|c|}{ Treatments $\uparrow$} & \multirow[b]{2}{*}{ Avg. } \\
\hline & Bss & BssB & BssH & BssBH & Gss & GssB & GssH & GssBH & \\
\hline & & & & & $\%$ & & & & \\
\hline Herbaceous & $2^{\mathrm{c} *}$ & $1^{\mathrm{c}}$ & $12^{\mathrm{bc}}$ & $19^{\mathrm{b}}$ & $0^{\mathrm{c}}$ & $1^{\mathrm{c}}$ & $8^{\mathrm{bc}}$ & $34^{\mathrm{a}}$ & 10 \\
\hline Bark/litter & $0^{\mathrm{c}}$ & $81^{\mathrm{a}}$ & $0^{\mathrm{c}}$ & $58^{\mathrm{b}}$ & $0^{\mathrm{c}}$ & $82^{\mathrm{a}}$ & $0^{\mathrm{c}}$ & $51^{\mathrm{b}}$ & 34 \\
\hline Tree & $4^{\mathrm{a}}$ & $3^{a}$ & $4^{\mathrm{a}}$ & $1^{\mathrm{a}}$ & $1^{\mathrm{a}}$ & $2^{\mathrm{a}}$ & $1^{\mathrm{a}}$ & $3^{\mathrm{a}}$ & 2 \\
\hline Total & $7^{\mathrm{bc}}$ & $85^{\mathrm{a}}$ & $16^{\mathrm{b}}$ & $78^{\mathrm{a}}$ & $1^{\mathrm{c}}$ & $86^{\mathrm{a}}$ & $9^{b c}$ & $88^{\mathrm{a}}$ & 46 \\
\hline Bare/rock & $93^{\mathrm{ab}}$ & $15^{\mathrm{c}}$ & $84^{\mathrm{b}}$ & $22^{c}$ & $99^{\mathrm{a}}$ & $14^{\mathrm{c}}$ & $91^{\mathrm{ab}}$ & $12^{\mathrm{c}}$ & 54 \\
\hline
\end{tabular}

\section{$\underline{\text { Tree survival and volume }}$}

After three growing seasons, there were 319 total trees sampled across the eleven tree species and eight treatment combinations (Table 3-9). This translates into an estimated 1002 
trees sampled per ha but does not include volunteer species that have become established on the site. Trees sampled by species across treatment combinations ranged from two for dogwood to 49 for red oak. Trees sampled by treatment including all trees were 16 for brown sandstone with bark mulch to 107 for brown sandstone with hydroseeding. Trees sampled by species and treatment combination ranged from zero for several species to 26 for red oak in the brown sandstone with hydroseeding treatment combination.

Table 3-9 Number of trees sampled after two growing seasons in eight soil treatment combinations at ICG Eastern, LLC's Birch River Operation in Webster County, WV

\begin{tabular}{lccccccccc}
\hline & \multicolumn{1}{c}{ Treatments $\dagger$} \\
\cline { 2 - 10 } Species & Bss & BssB & BssH & BssBH & Gss & GssB & GssH & GssBH & Total \\
\hline Black cherry & 4 & 2 & 10 &. & 7 & 2 & 1 & 2 & 28 \\
Black locust & 7 & 4 & 13 & 6 & 6 & 4 & 3 &. & 43 \\
Dogwood & 0 &. & 1 & 0 & 0 & 1 & 0 & 0 & 2 \\
Redbud & 2 & 1 & 0 &. & 2 & 0 &. &. & 5 \\
Red oak & 5 & 1 & 26 &. & 8 & 4 & 2 & 3 & 49 \\
Sugar maple & 6 & 1 & 12 & 2 & 5 & 3 & 4 & 4 & 37 \\
Sycamore & 9 &. & 6 & 2 & 1 &. & 0 & 2 & 20 \\
Tulip poplar & 5 & 1 & 4 & 2 & 5 & 3 & 1 & 1 & 22 \\
White ash & 8 & 2 & 12 & 3 & 4 & 5 & 0 & 1 & 35 \\
White oak & 11 & 1 & 13 & 3 & 4 & 1 & 2 & 2 & 37 \\
White pine & 12 & 3 & 10 & 2 & 9 & 1 & 3 & 1 & 41 \\
Total & 69 & 16 & 107 & 20 & 51 & 24 & 16 & 16 & 319 \\
\hline
\end{tabular}

$\dagger$ See table 3-1 for treatment descriptions

- no trees were planted and/or recorded in the first year of sampling

0 all trees planted had died after three growing seasons

For the populations of trees which had a sufficient $\mathrm{n}$ number for statistical analysis, there were no significant differences in tree survival by substrate, bark mulch, or hydroseeding with ranges of 74 to $80 \%$ (Table 3-10). This is somewhat surprising when such large differences were found for $\mathrm{pH}$ and percent fines among substrate treatments. There were also no significant differences in volume for bark mulch or hydroseeding, which ranged from $184 \mathrm{~cm}^{3}$ to $309 \mathrm{~cm}^{3}$. However, there were significant differences in volume in brown vs. gray sandstone substrates. Trees in the brown sandstone had a volume of $313 \mathrm{~cm}^{3}$ compared to $100 \mathrm{~cm}^{3}$ in the gray. This is similar to results found by Emerson et al. (2009) and Angel et al. (2008) who found no 
differences in survival in brown vs. gray sandstone substrates, but did find that trees in brown sandstone substrates had greater volume than trees in gray sandstone. Survival by species across treatments was fairly uniform ranging from 56 to $85 \%$, and an overall average of $76 \%$ survival across all species. Sycamore had significantly lower survival (56\%) of all the species with the exception of sugar maple (67\%). Species volume varied greatly across species ranging from 13 $\mathrm{cm}^{3}$ for sugar maple to $1086 \mathrm{~cm}^{3}$ black locust. Black locust had significantly greater volume $\left(1086 \mathrm{~cm}^{3}\right)$ than all other species and no additional volume differences were found between species.

Table 3-10 Main treatment effects (substrate, bark, hydro) and species survival and volume after two growing seasons in eight soil treatment combinations at ICG Eastern, LLC's Birch River Operation in Webster County, WV

\begin{tabular}{|c|c|c|c|}
\hline & & Survival & Volume \\
\hline \multirow[t]{7}{*}{ Treatment } & & $\%$ & $\mathrm{~cm}^{3}$ \\
\hline & Brown & $76^{\mathrm{a}}$ & $313^{a}$ \\
\hline & Gray & $78^{\mathrm{a}}$ & $100^{\mathrm{b}}$ \\
\hline & w/ bark & $80^{\mathrm{a}}$ & $309^{\mathrm{a}}$ \\
\hline & w/o bark & $76^{\mathrm{a}}$ & $228^{\mathrm{a}}$ \\
\hline & w/ hydroseeding & $74^{\mathrm{a}}$ & $306^{\mathrm{a}}$ \\
\hline & w/o hydroseeding & $80^{\mathrm{a}}$ & $184^{\mathrm{a}}$ \\
\hline \multicolumn{4}{|l|}{ Species } \\
\hline & Black cherry & $83^{\mathrm{a}}$ & $216^{\mathrm{b}}$ \\
\hline & Black locust & $83^{a}$ & $1086^{\mathrm{a}}$ \\
\hline & Red oak & $79^{\mathrm{ab}}$ & $100^{\mathrm{b}}$ \\
\hline & Sugar maple & $67^{\mathrm{bc}}$ & $13^{\mathrm{b}}$ \\
\hline & Sycamore & $56^{\mathrm{c}}$ & $81^{\mathrm{b}}$ \\
\hline & Tulip poplar & $76^{\mathrm{ab}}$ & $220^{\mathrm{b}}$ \\
\hline & White ash & $73^{\mathrm{ab}}$ & $122^{\mathrm{b}}$ \\
\hline & White oak & $85^{\mathrm{a}}$ & $58^{\mathrm{b}}$ \\
\hline & White pine & $85^{\mathrm{a}}$ & $102^{b}$ \\
\hline & Average & 76 & 222 \\
\hline
\end{tabular}

The average tree survival, volume, and vigor rating for all eleven species across the eight treatment combinations was $69 \%, 178 \mathrm{~cm}^{3}$, and good to very good (4.1) after three growing 
seasons (Tables 3-11, 3-12, 3-13). The average survival for trees across treatment combinations ranged from $85 \%$ for sugar maple to $16 \%$ for dogwood, average volume ranged from $806 \mathrm{~cm}^{3}$ for black locust to $3 \mathrm{~cm}^{3}$ for dogwood, and vigor rating ranged from good to very good (4.8) for white pine to poor to moderate (2.9) for sugar maple. The average survival of trees across species ranged from $84 \%$ in the brown sandstone with bark mulch to $50 \%$ in the gray sandstone with hydroseeding, average volume ranged from $283 \mathrm{~cm}^{3}$ in the brown sandstone with hydroseeding to $30 \mathrm{~cm}^{3}$ in the gray sandstone alone, and the average vigor rating ranged from good to very good (4.5) in the brown sandstone with bark mulch to moderate to good (3.1) in the gray sandstone alone treatment combinations.

Table 3-11 Survival of eleven species of trees after two growing seasons in eight soil treatment combinations at ICG Eastern, LLC's Birch River Operation in Webster County, WV

\begin{tabular}{lccccccccc}
\hline & \multicolumn{7}{c}{ Treatments $\uparrow$} \\
\cline { 2 - 10 } Species & Bss & BssB & BssH & BssBH & Gss & GssB & GssH & GssBH & Avg. \\
\hline Black cherry & 57 & 100 & 91 &. & 88 & 100 & 100 & 50 & 84 \\
Black locust & 78 & 80 & 87 & 75 & 86 & 100 & 75 &. & 83 \\
Dogwood & 0 &. & 14 & 0 & 0 & 100 & 0 & 0 & 16 \\
Redbud & 40 & 50 & 0 &. & 100 & 0 &. &. & 38 \\
Red oak & 100 & 100 & 81 &. & 80 & 67 & 50 & 75 & 79 \\
Sugar maple & 43 & 100 & 57 & 100 & 83 & 100 & 100 & 100 & 85 \\
Sycamore & 75 &. & 46 & 50 & 33 &. & 0 & 40 & 41 \\
Tulip poplar & 83 & 50 & 50 & 67 & 100 & 100 & 33 & 100 & 73 \\
White ash & 89 & 100 & 80 & 100 & 44 & 83 & 0 & 100 & 75 \\
White oak & 100 & 100 & 81 & 100 & 67 & 50 & 67 & 100 & 83 \\
White pine & 100 & 75 & 91 & 50 & 82 & 50 & 75 & 100 & 78 \\
Avg. & 70 & 84 & 62 & 68 & 69 & 75 & 50 & 74 & 69 \\
\hline
\end{tabular}

$\dagger$ See table 3-1 for treatment descriptions

+ Indicated no trees were sampled in that treatment 
Table 3-12 Volume of eleven species of trees after two growing seasons in eight soil treatment combinations at ICG Eastern, LLC's Birch River Operation in Webster County, WV

\begin{tabular}{lccccccccc}
\hline & \multicolumn{7}{c}{ Treatments $\dagger$} \\
\cline { 2 - 10 } Species & Bss & BssB & BssH & BssBH & Gss & GssB & GssH & GssBH & Avg. \\
\hline Black cherry & 375 & 485 & 199 &. & 31 & 314 & 4 & 65 & 211 \\
Black locust & 1143 & 499 & 2001 & 1324 & 83 & 477 & 113 &. & 806 \\
Dogwood &. &. & 2 &. &. & 4 &. &. & 3 \\
Redbud & 47 & 37 &. &. & 4 &. &. &. & 29 \\
Red oak & 113 & 104 & 139 &. & 20 & 84 & 27 & 24 & 73 \\
Sugar maple & 30 & 18 & 12 & 26 & 9 & 12 & 3 & 3 & 14 \\
Sycamore & 89 &. & 62 & 82 & 23 &. &. & 102 & 71 \\
Tulip poplar & 87 & 963 & 128 & 91 & 56 & 923 & 65 & 237 & 319 \\
White ash & 142 & 77 & 126 & 98 & 37 & 180 &. & 36 & 99 \\
White oak & 63 & 6 & 67 & 32 & 14 & 7 & 5 & 159 & 44 \\
White pine & 189 & 31 & 89 & 186 & 23 & 27 & 49 & 60 & 82 \\
Avg. & 228 & 247 & 283 & 263 & 30 & 225 & 38 & 86 & 178 \\
\hline
\end{tabular}

$\uparrow$ See table 3-1 for treatment descriptions

Table 3-13 Vigor of eleven species of trees after two growing seasons in eight soil treatment combinations at ICG Eastern, LLC's Birch River Operation in Webster County, WV

\begin{tabular}{lccccccccc}
\hline & \multicolumn{8}{c}{ Treatments $\dagger$} \\
\cline { 2 - 10 } Species & Bss & BssB & BssH & BssBH & Gss & GssB & GssH & GssBH & Avg. \\
\hline Black Cherry & 5.0 & 5.0 & 4.5 &. & 3.9 & 4.5 & 3.0 & 4.0 & 4.3 \\
Black Locust & 4.7 & 4.5 & 5.0 & 5.0 & 1.8 & 5.0 & 5.0 &. & 4.4 \\
Dogwood &. &. & 2.0 &. &. & 4.0 &. &. & 3.0 \\
Redbud & 5.0 & 5.0 &. &. & 2.0 &. &. &. & 4.0 \\
Red Oak & 4.8 & 4.0 & 4.5 &. & 3.0 & 4.5 & 3.0 & 3.0 & 3.8 \\
Sugar Maple & 3.3 & 3.0 & 3.0 & 2.5 & 3.0 & 3.3 & 2.5 & 2.5 & 2.9 \\
Sycamore & 4.2 &. & 4.2 & 5.0 & 3.0 &. &. & 5.0 & 4.3 \\
Tulip Poplar & 4.0 & 5.0 & 4.8 & 4.5 & 3.6 & 4.3 & 4.0 & 5.0 & 4.4 \\
White Ash & 4.8 & 5.0 & 4.5 & 5.0 & 4.0 & 4.6 &. & 5.0 & 4.7 \\
White Oak & 4.6 & 4.0 & 4.1 & 3.7 & 2.5 & 4.0 & 3.5 & 5.0 & 3.9 \\
White Pine & 5.0 & 4.7 & 4.6 & 5.0 & 4.3 & 5.0 & 4.7 & 5.0 & 4.8 \\
Avg. & 4.5 & 4.5 & 4.1 & 4.4 & 3.1 & 4.4 & 3.7 & 4.3 & 4.1 \\
\hline
\end{tabular}

$\dagger$ See table 3-1 for treatment descriptions

Black cherry had the second highest average survival across the eight soil treatment combinations at $84 \%$ with an average volume of $211 \mathrm{~cm}^{3}$ and a good to very good vigor rating of 4.3. The highest average survival $(100 \%)$ was recorded in the brown sandstone with bark mulch, gray sandstone with bark mulch, and gray sandstone with hydroseeding treatments while the lowest $(50 \%)$ was recorded in the gray sandstone with bark mulch and with hydroseeding. The greatest volume $\left(485 \mathrm{~cm}^{3}\right)$ was recorded in the brown sandstone with bark mulch while the least 
$\left(4 \mathrm{~cm}^{3}\right)$ was recorded in the gray sandstone with hydroseeding. The highest average vigor rating (5.0) was recorded in the brown sandstone alone and brown sandstone with bark mulch treatments while the lowest (3.0) was recorded in the gray sandstone with hydroseeding treatment. Species survival, height, diameter, and volume for the length of the study can be seen in Figures 3-1a through 3-1d. Black cherry had greater volume in the brown sandstone treatments compared to the gray sandstone and the addition of bark mulch could have improved site conditions to be similar to preferred conditions of rich, moist sites mentioned in Chapter 1.

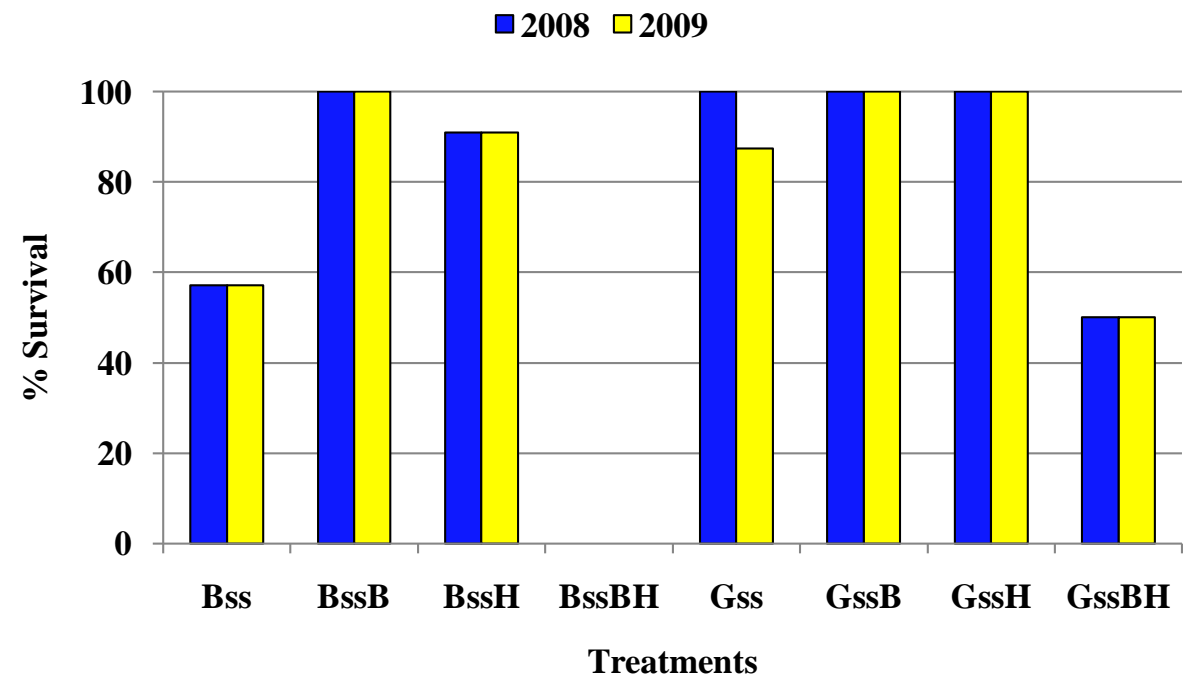

Figure 3-1a. Average survival of black cherry for two growing seasons in eight soil treatment combinations at ICG Eastern, LLC's Birch River Operation in Webster County, WV

Bss=brown sandstone, BssB=brown sandstone bark mulch, $\mathrm{BssH}=$ brown sandstone hydroseeded, $\mathrm{Bss} \mathrm{BH}=$ brown sandstone hydroseeded and bark mulch, Gss=gray sandstone, GssB=gray sandstone bark mulch, GssH=gray sandstone hydroseeded, GssBH=gray sandstone hydroseeded and bark mulch 


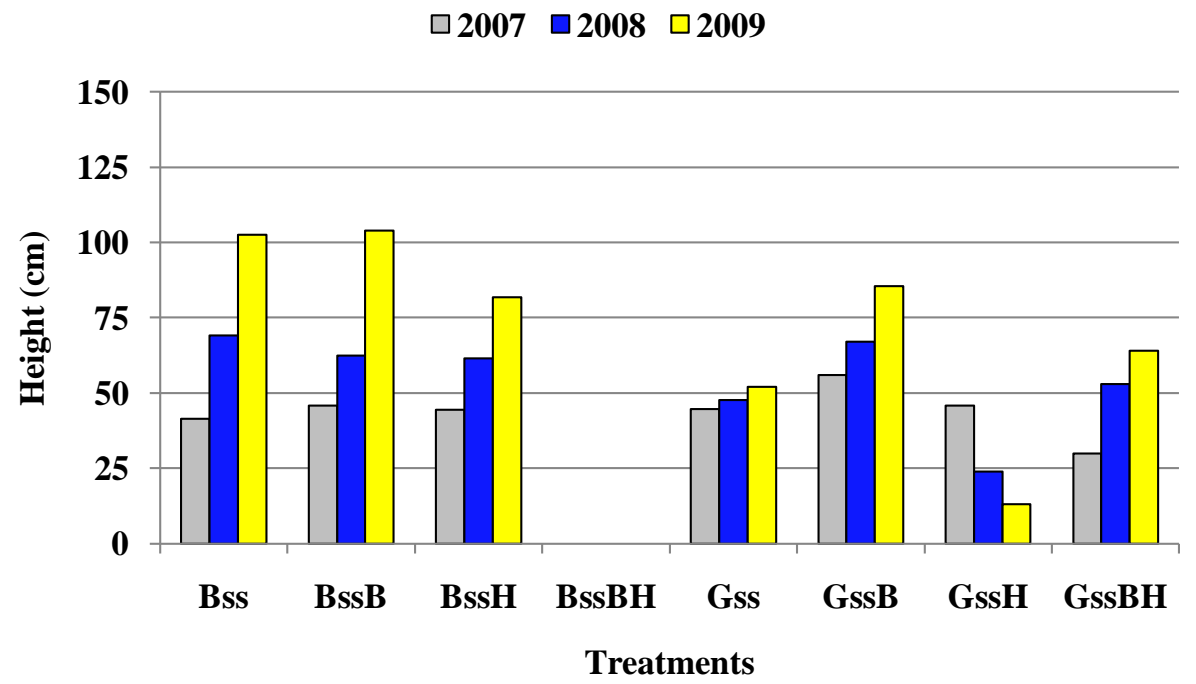

Figure 3-1b. Average height of black cherry for three growing seasons in eight soil treatment combinations at ICG Eastern, LLC's Birch River Operation in Webster County, WV

$$
\square 2007 \square 2008 \square 2009
$$

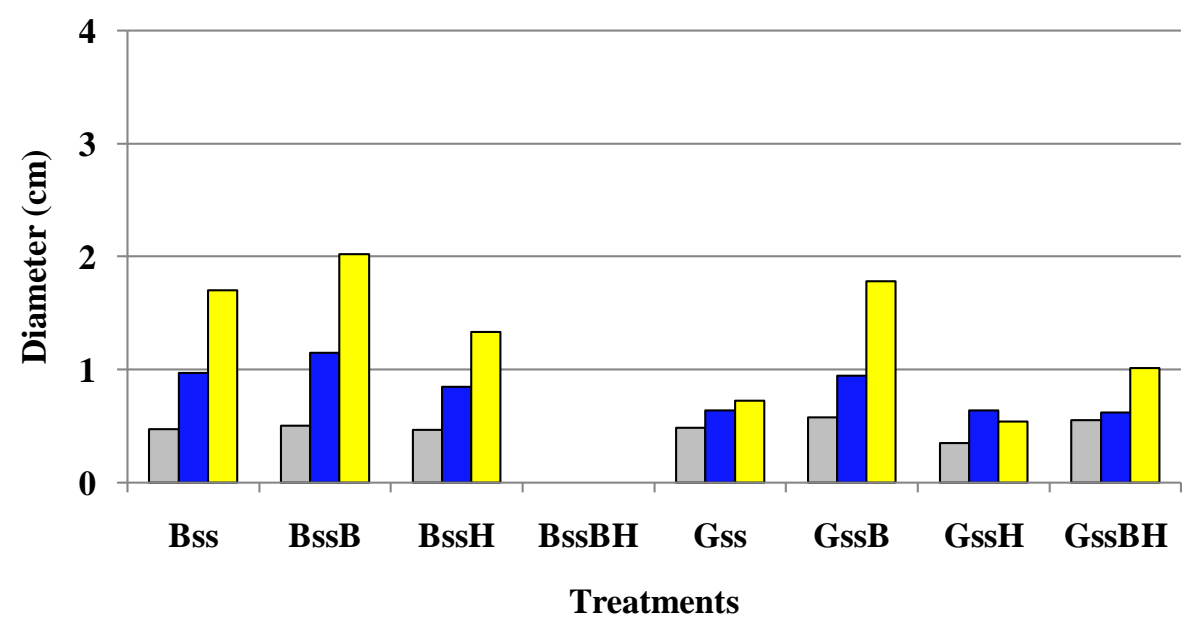

Figure 3-1c. Average diameter of black cherry for three growing seasons in eight soil treatment combinations at ICG Eastern, LLC's Birch River Operation in Webster County, WV 


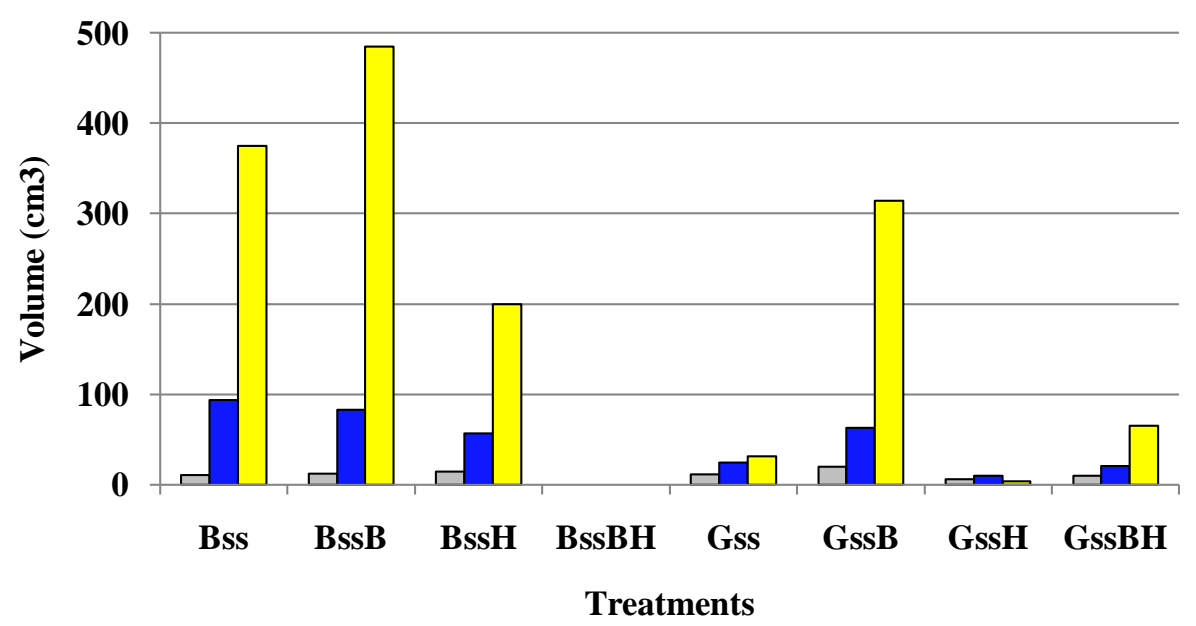

Figure 3-1d. Average volume of black cherry for three growing seasons in eight soil treatment combinations at ICG Eastern, LLC's Birch River Operation in Webster County, WV

Black locust had the third highest average survival across the eight soil treatment combinations at $83 \%$ with an average volume of $806 \mathrm{~cm}^{3}$ and a good to very good vigor rating of 4.4. The highest average survival (100\%) was recorded in the gray sandstone with bark mulch treatment while the lowest $(75 \%)$ was recorded in the brown sandstone with bark mulch and with hydroseeding and the gray sandstone with hydroseeding treatments. The greatest average volume $\left(2001 \mathrm{~cm}^{3}\right)$ was recorded in the brown sandstone with hydroseeding treatment while the least (83 $\mathrm{cm}^{3}$ ) was recorded in the gray sandstone alone treatment. The highest average vigor rating (5.0) was recorded in the brown sandstone with hydroseeding, brown sandstone with bark mulch and with hydroseeding, gray sandstone with bark mulch, and gray sandstone with hydroseeding treatments while the lowest (1.8) was recorded in the gray sandstone alone treatment. Species survival, height, diameter, and volume for the length of the study can be seen in Figures 3-2a through 3-2d. Black locust performance was similar to the study by Emerson et al. (2009) in which average volume was significantly greater than all other species used for reclamation on the site. The bark mulch application increased volume in the gray sandstone treatments but did not 
show an increase in volume for the brown sandstone treatments. Growth between 2008 and 2009 was especially impressive on most of the sites.

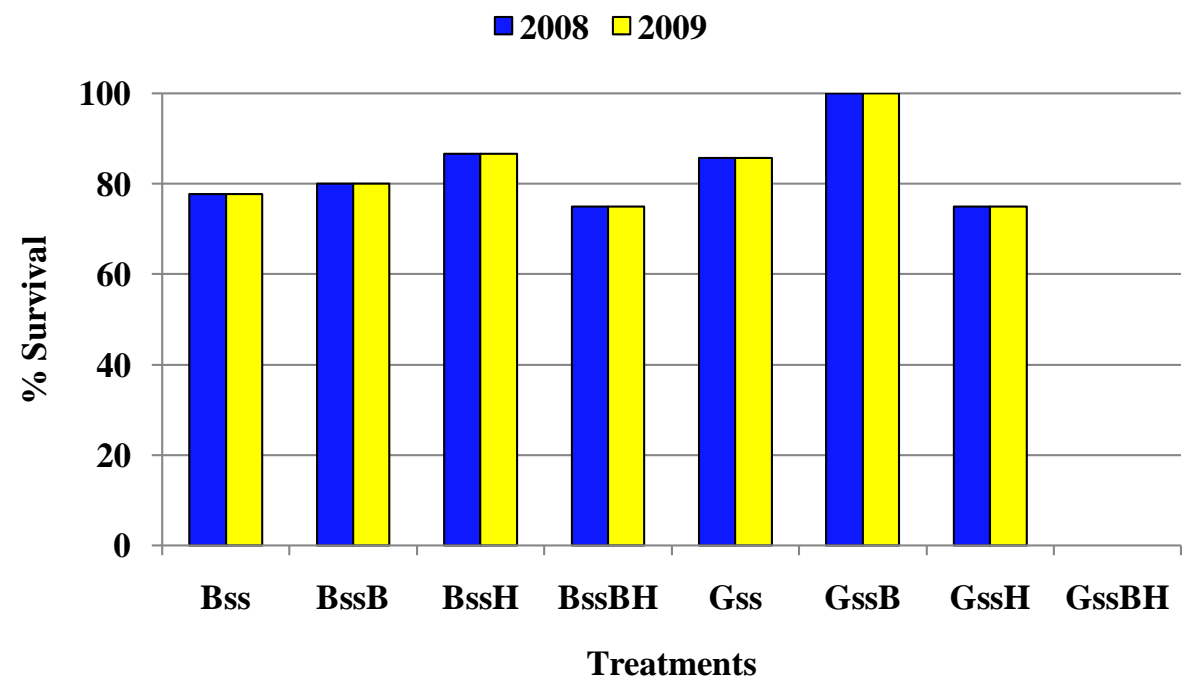

Figure 3-2a. Average survival of black locust for two growing seasons in eight soil treatment combinations at ICG Eastern, LLC's Birch River Operation in Webster County, WV

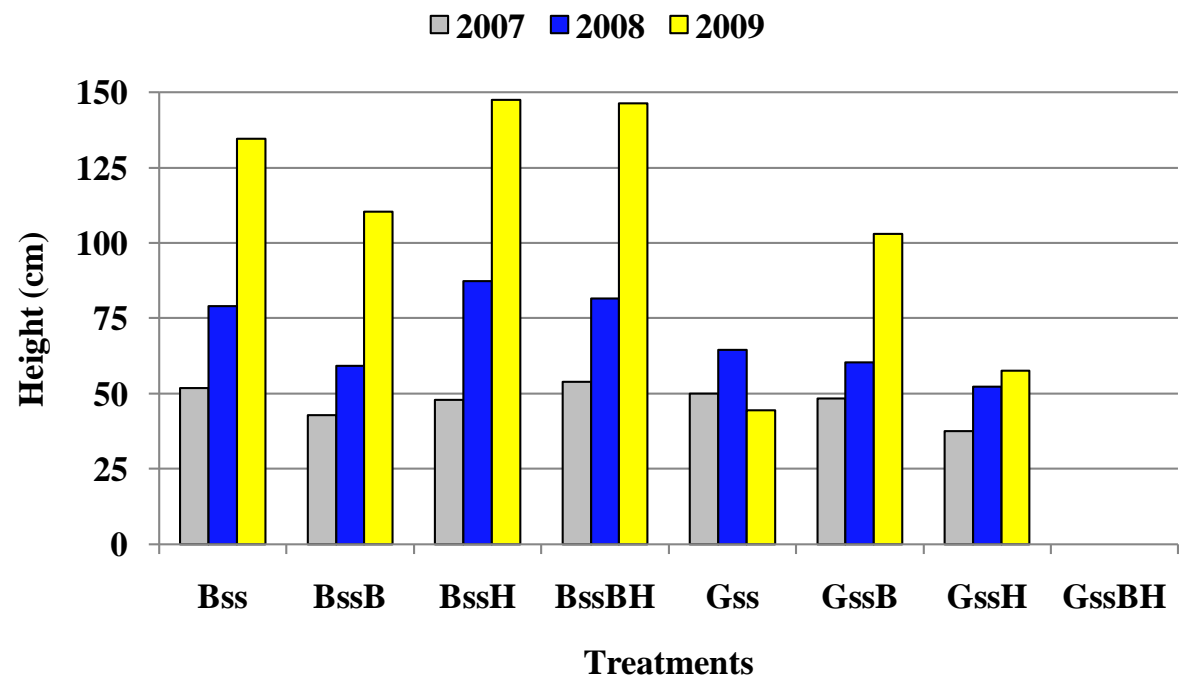

Figure 3-2b. Average height of black locust for three growing seasons in eight soil treatment combinations at ICG Eastern, LLC's Birch River Operation in Webster County, WV 


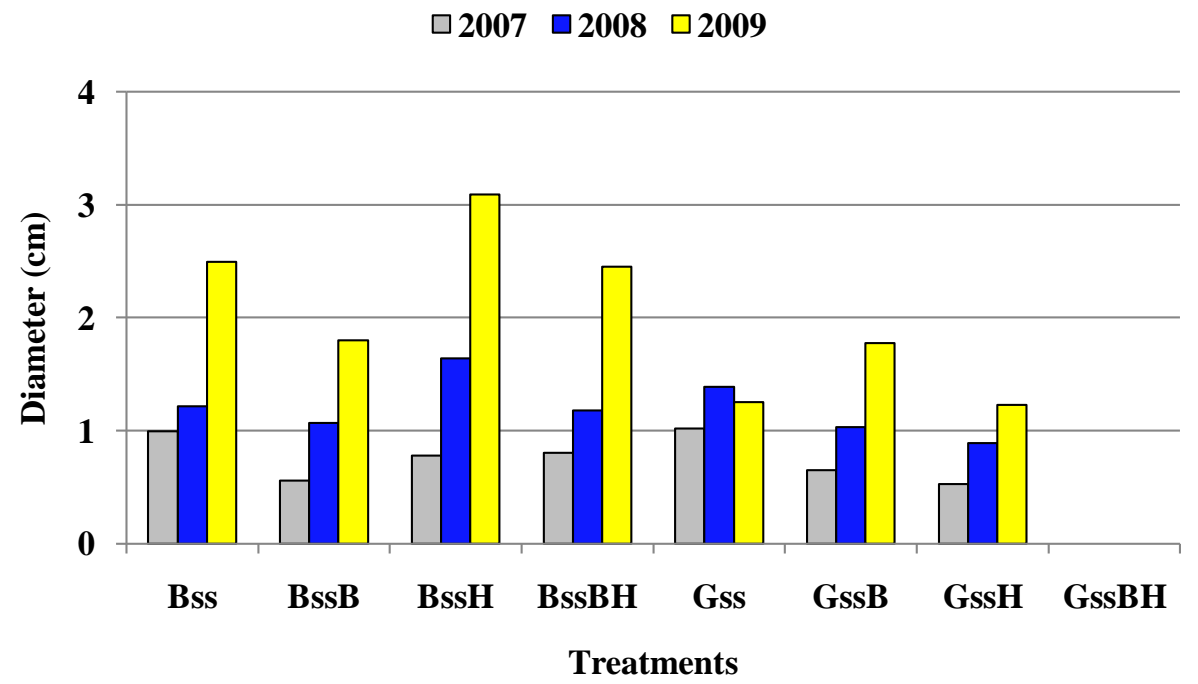

Figure 3-2c. Average diameter of black locust for three growing seasons in eight soil treatment combinations at ICG Eastern, LLC's Birch River Operation in Webster County, WV

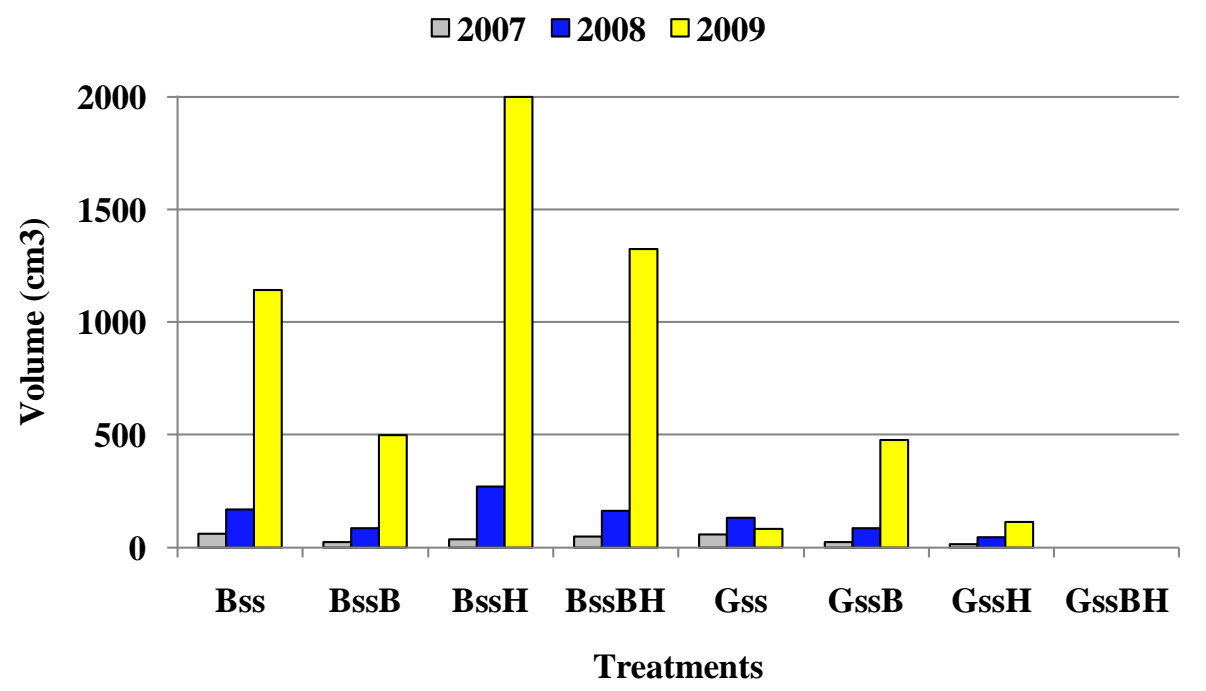

Figure 3-2d. Average volume of black locust for three growing seasons in eight soil treatment combinations at ICG Eastern, LLC's Birch River Operation in Webster County, WV

Dogwood had the lowest average survival across the eight soil treatment combinations at $16 \%$ with an average volume of $3 \mathrm{~cm}^{3}$ and a moderate vigor rating of 3.0 . The highest average survival $(100 \%)$ was recorded in the gray sandstone with bark mulch treatment while the lowest $(0 \%)$ was recorded in the brown sandstone alone, brown sandstone with hydroseeding, gray sandstone alone, gray sandstone with hydroseeding, and gray sandstone with bark mulch and with hydroseeding treatments. The greatest average volume $\left(4 \mathrm{~cm}^{3}\right)$ was recorded in the gray 
sandstone alone treatment while the least $\left(2 \mathrm{~cm}^{3}\right)$ was recorded in the brown sandstone with hydroseeding treatment. The highest average vigor rating (4.0) was recorded in the gray sandstone alone while the lowest (2.0) was recorded in the brown sandstone with hydroseeding treatment. Species survival, height, diameter, and volume for the length of the study can be seen in Figures 3-3a through 3-3d. Skousen et al. (2006) found that dogwood will grow on surface mined lands and will colonize as a volunteer. However, the site in the study by Skousen et al. (2006) was 22 years of age which could indicate that dogwood is more likely to move into an area and have success after a forest canopy is established and the site conditions, detailed in Chapter 1, are more favorable.

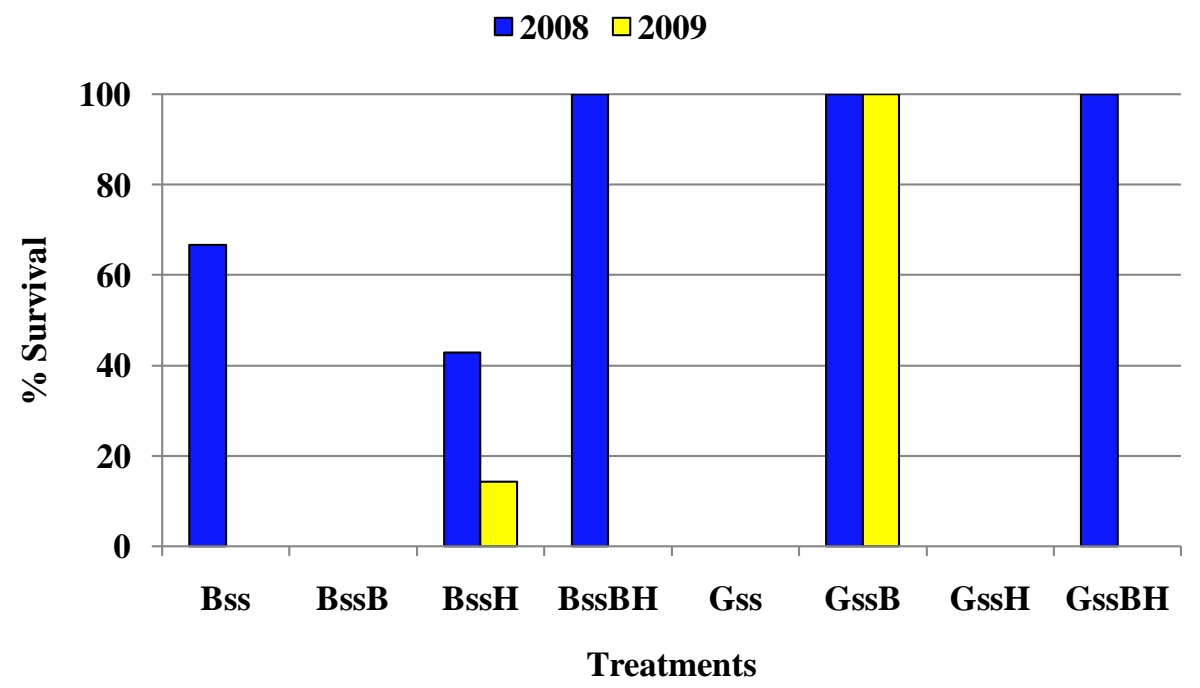

Figure 3-3a. Average survival of dogwood for two growing seasons in eight soil treatment combinations at ICG Eastern, LLC's Birch River Operation in Webster County, WV 


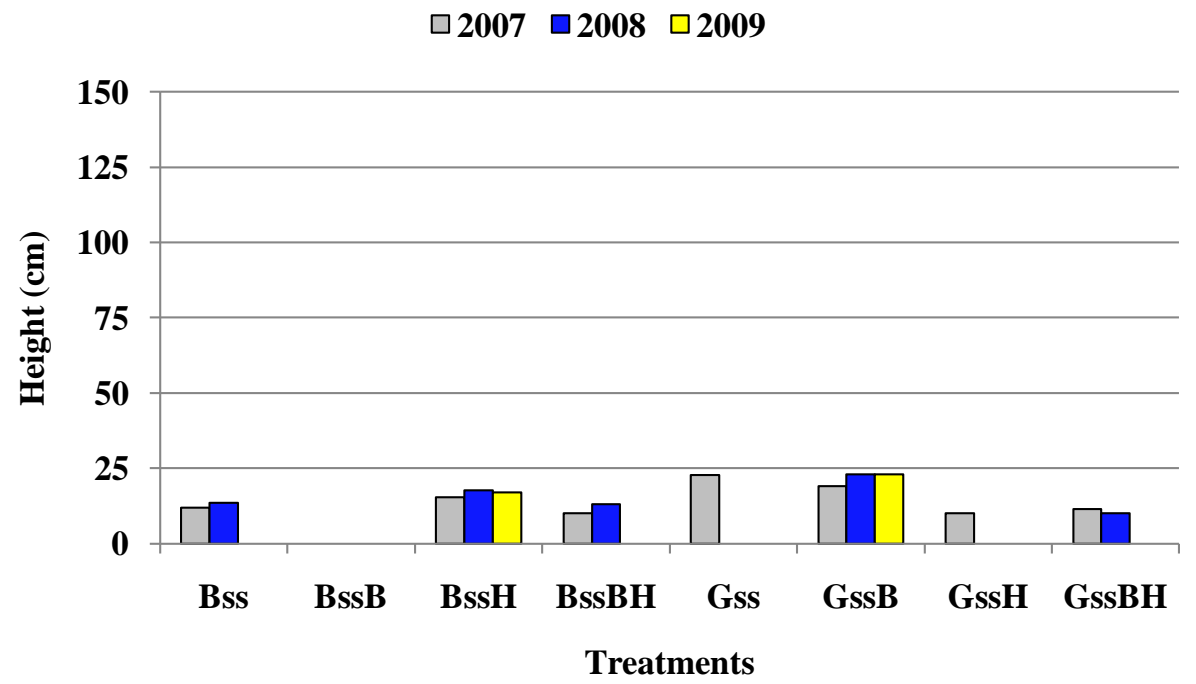

Figure 3-3b. Average height of dogwood for three growing seasons in eight soil treatment combinations at ICG Eastern, LLC's Birch River Operation in Webster County, WV

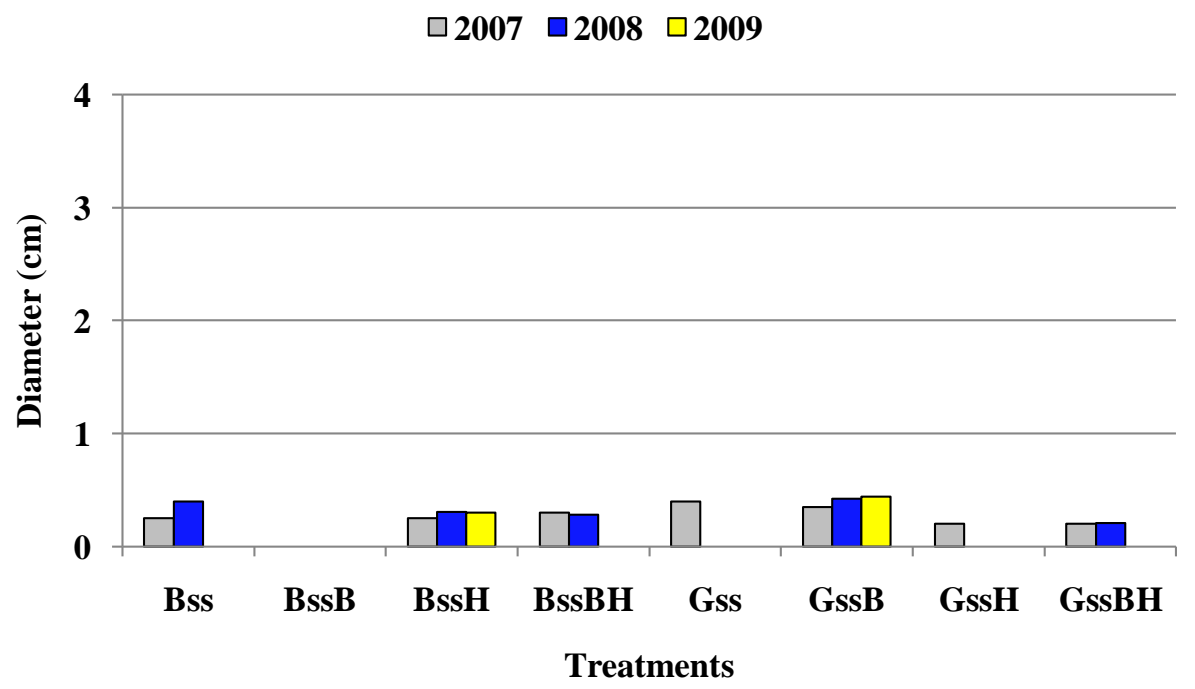

Figure 3-3c. Average diameter of dogwood for three growing seasons in eight soil treatment combinations at ICG Eastern, LLC's Birch River Operation in Webster County, WV 


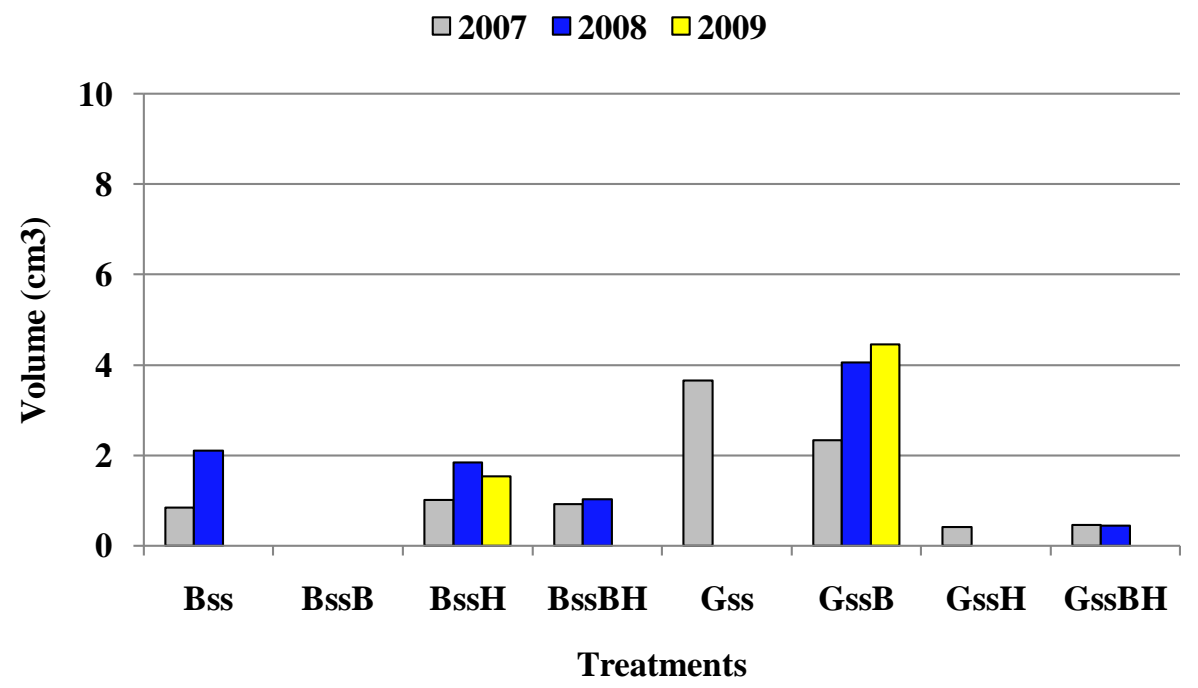

Figure 3-3d. Average volume of dogwood for three growing seasons in eight soil treatment combinations at ICG Eastern, LLC's Birch River Operation in Webster County, WV

Redbud had the second lowest average survival across the eight soil treatment combinations at $38 \%$ with an average volume of $20 \mathrm{~cm}^{3}$ and a good vigor rating of 4.0 . The highest average survival $(100 \%)$ was recorded in the gray sandstone alone treatment while the lowest $(0 \%)$ was recorded in the brown sandstone with hydroseeding and gray sandstone with bark mulch treatments. The greatest average volume $\left(47 \mathrm{~cm}^{3}\right)$ was recorded in the brown sandstone alone treatment while the least $\left(4 \mathrm{~cm}^{3}\right)$ was recorded in the gray sandstone alone treatment. The highest average vigor rating (5.0) was recorded in the brown sandstone alone and brown sandstone with bark mulch treatments while the lowest (2.0) was recorded in the gray sandstone alone treatment. Species survival, height, diameter, and volume for the length of the study can be seen in Figures 3-4a through 3-4d. Redbud performance in this study was relatively poor and fits with its intolerance of sunny conditions and harsh soils. Growth would be expected to increase as the tree canopy increases and provides shade and cooler conditions more favorable for growth. 
$\square 2008 \square 2009$

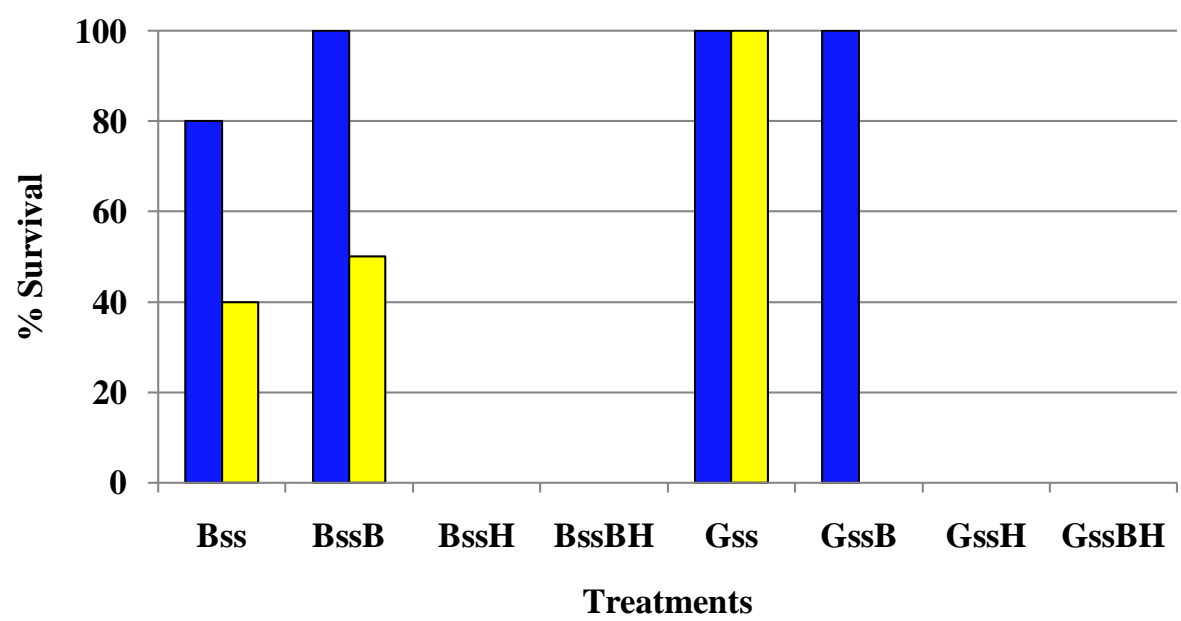

Figure 3-4a. Average survival of redbud for two growing seasons in eight soil treatment combinations at ICG Eastern, LLC's Birch River Operation in Webster County, WV

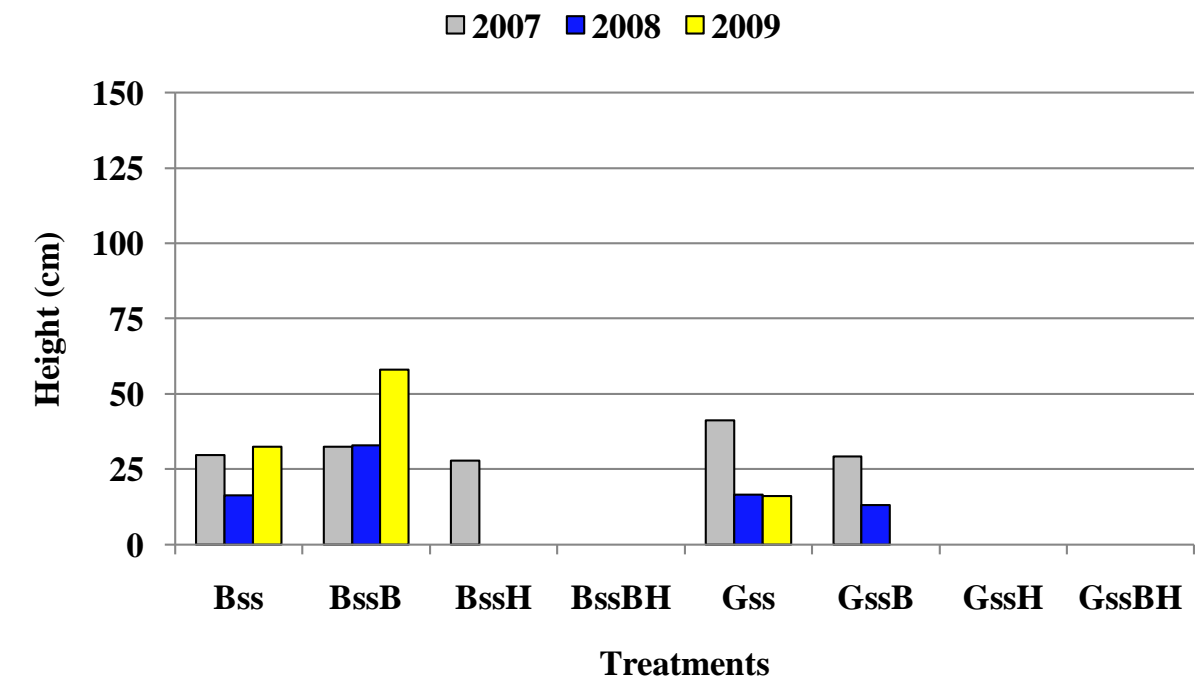

Figure 3-4b. Average height of redbud for three growing seasons in eight soil treatment combinations at ICG Eastern, LLC's Birch River Operation in Webster County, WV 


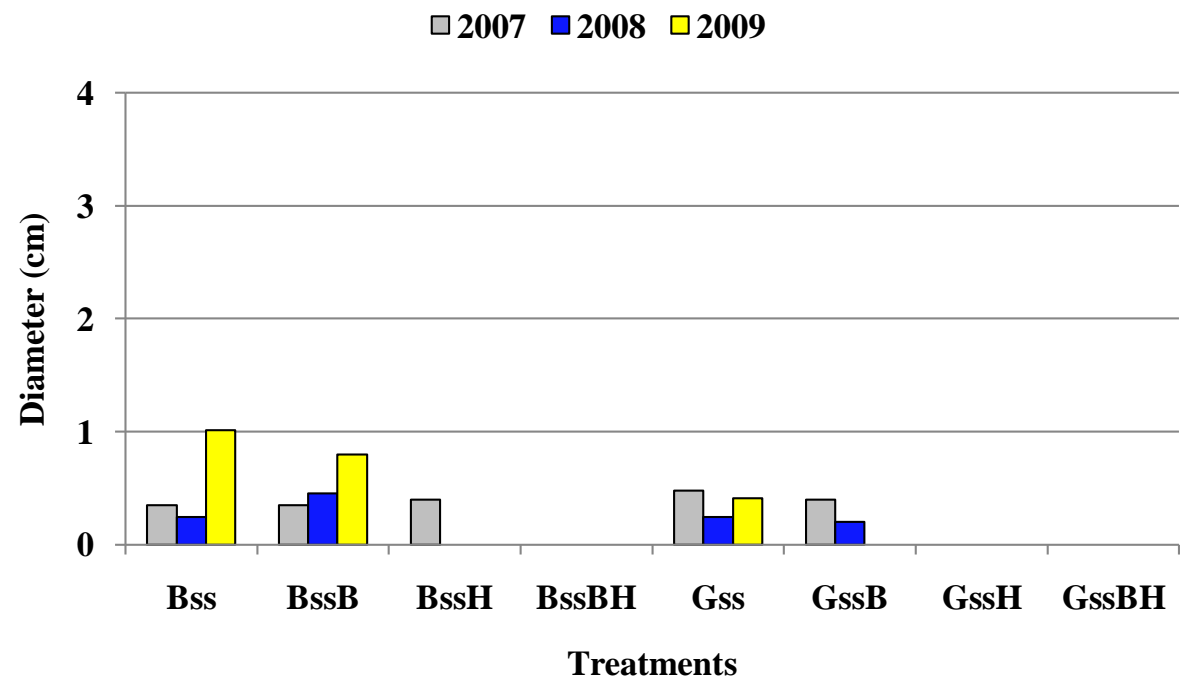

Figure 3-4c. Average diameter of redbud for three growing seasons in eight soil treatment combinations at ICG Eastern, LLC's Birch River Operation in Webster County, WV

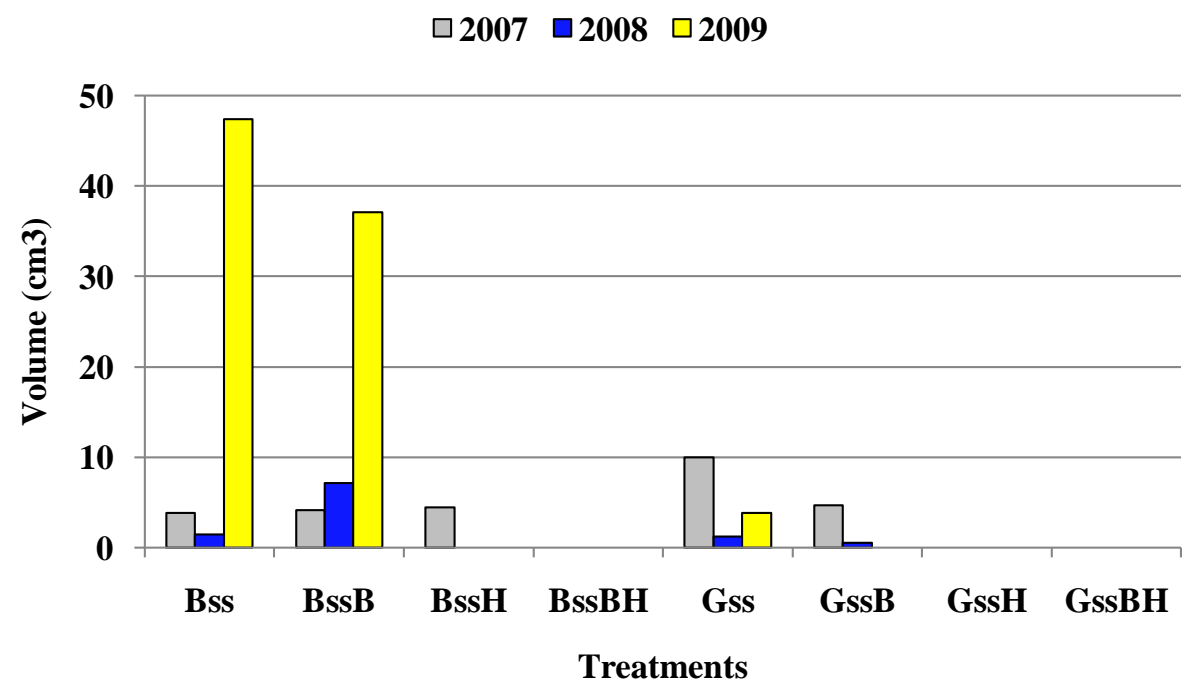

Figure 3-4d. Average volume of redbud for three growing seasons in eight soil treatment combinations at ICG Eastern, LLC's Birch River Operation in Webster County, WV

Red oak had the fifth highest average survival across the eight soil treatment combinations at $79 \%$ with an average volume of $73 \mathrm{~cm}^{3}$ and a moderate to good vigor rating of 3.8. The highest average survival $(100 \%)$ was recorded in the brown sandstone alone and brown sandstone with bark mulch treatments while the lowest (50\%) was recorded in the gray sandstone with hydroseeding treatment. The greatest average volume $\left(139 \mathrm{~cm}^{3}\right)$ was recorded in the brown sandstone with hydroseeding treatment while the least $\left(20 \mathrm{~cm}^{3}\right)$ was recorded in the gray 
sandstone alone treatment. The highest average vigor rating (4.8) was recorded in the brown sandstone alone treatment while the lowest (3.0) was recorded in the gray sandstone alone, gray sandstone with hydroseeding, and gray sandstone with bark mulch and with hydroseeding treatments. Species survival, height, diameter, and volume for the length of the study can be seen in Figures 3-5a through 3-5d. Its performance in this study on these harsh rocky soils was expected and amending these mine soils with bark and fertilizer (in the hydroseed mixture) showed improved growth and volume (Burger et al., 2007). Increases in volume were especially good between 2008 and 2009 (Figure 3-5d).

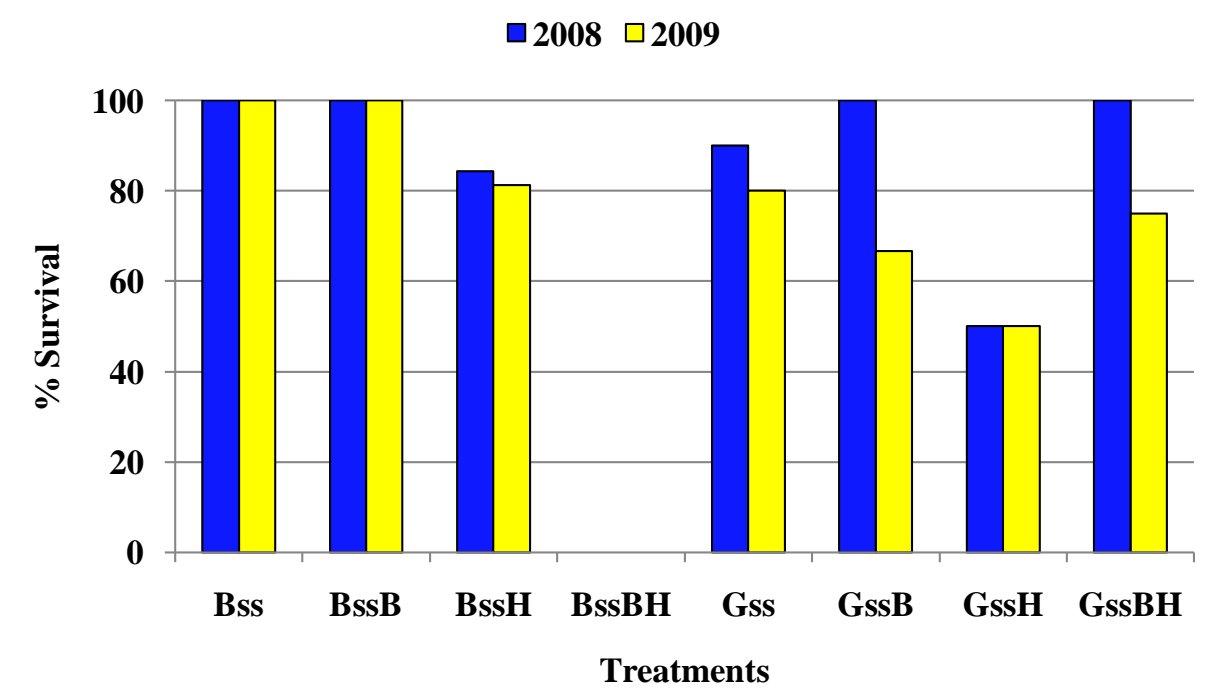

Figure 3-5a. Average survival of red oak for two growing seasons in eight soil treatment combinations at ICG Eastern, LLC's Birch River Operation in Webster County, WV 


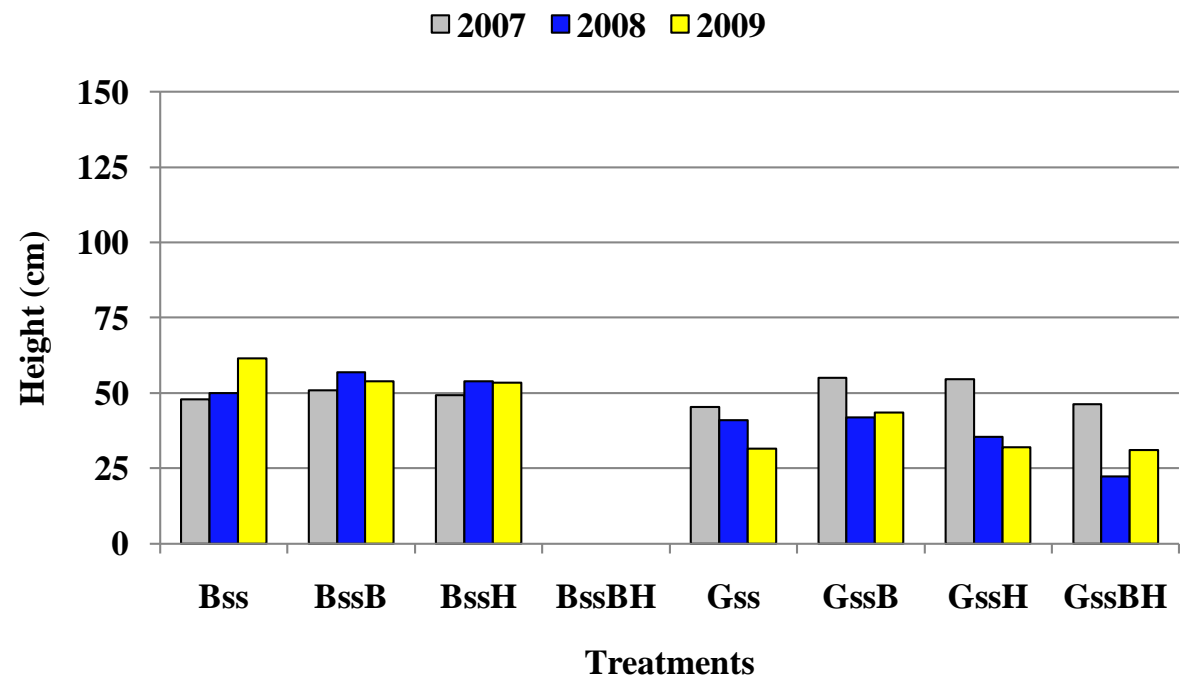

Figure 3-5b. Average height of red oak for three growing seasons in eight soil treatment combinations at ICG Eastern, LLC's Birch River Operation in Webster County, WV

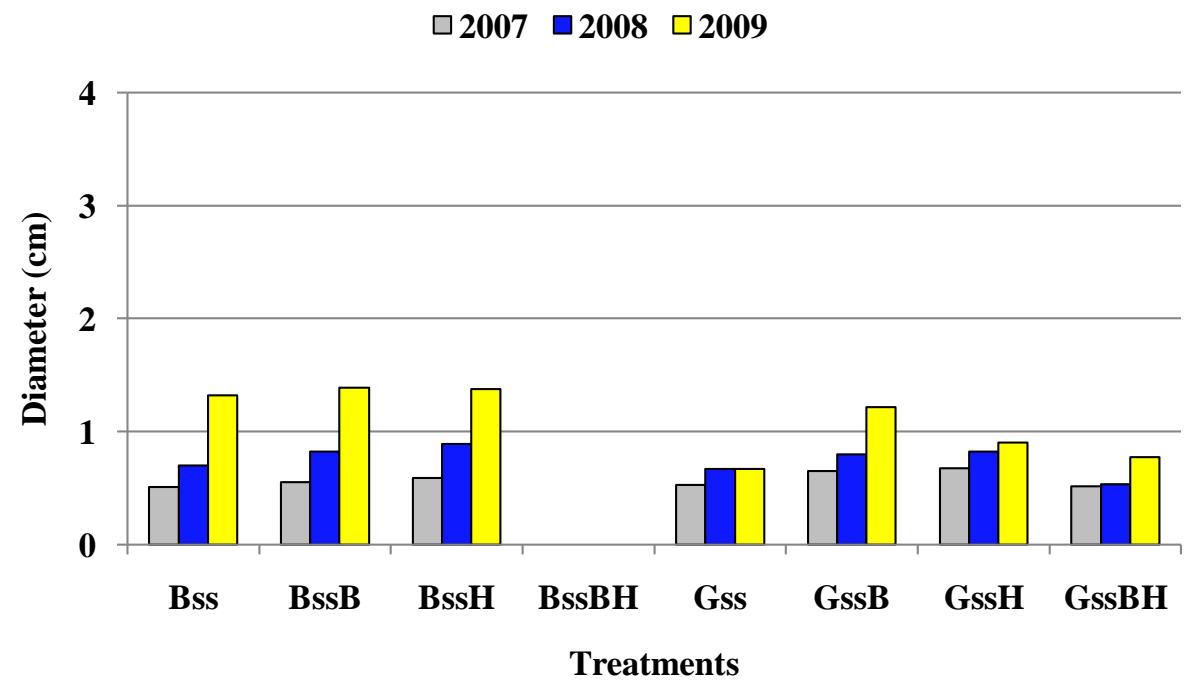

Figure 3-5c. Average diameter of red oak for three growing seasons in eight soil treatment combinations at ICG Eastern, LLC's Birch River Operation in Webster County, WV 


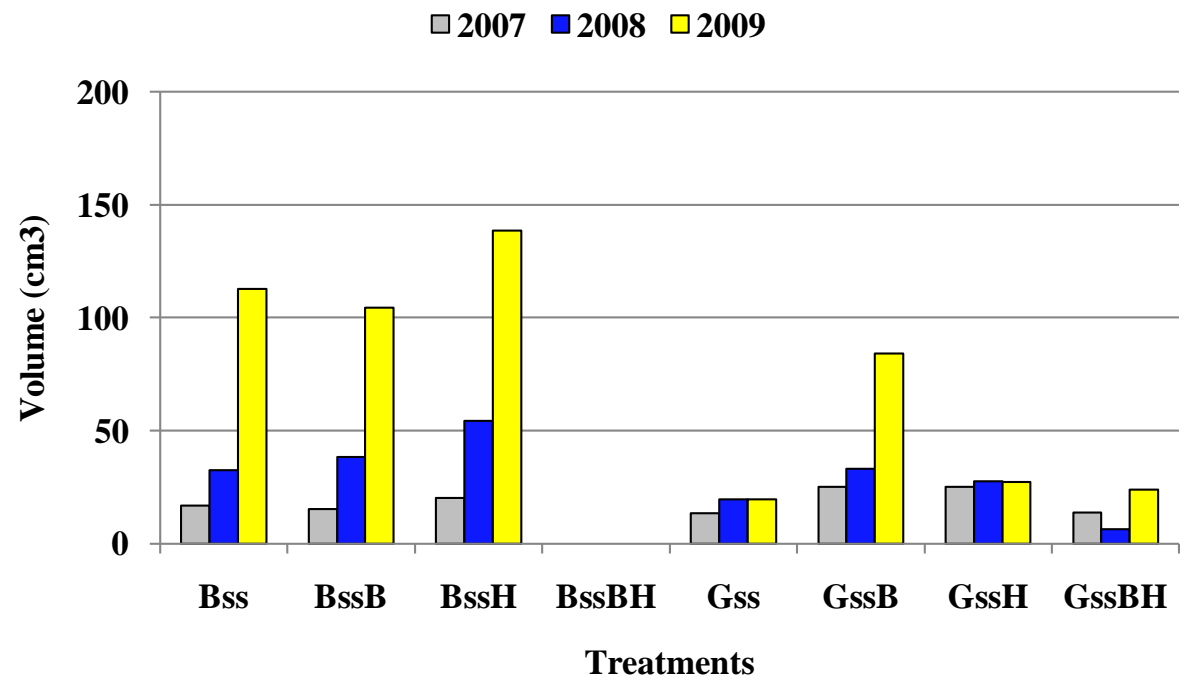

Figure 3-5d. Average volume of red oak for three growing seasons in eight soil treatment combinations at ICG Eastern, LLC's Birch River Operation in Webster County, WV

Sugar maple had the highest average survival across the eight soil treatment combinations at $85 \%$ with an average volume of $14 \mathrm{~cm}^{3}$ with a poor to moderate vigor rating of 2.9. The highest average survival $(100 \%)$ was recorded in the brown sandstone with bark mulch, brown sandstone with bark mulch and hydroseeding, gray sandstone with bark mulch, gray sandstone with hydroseeding, and gray sandstone with bark mulch and with hydroseeding treatments while the lowest $(43 \%)$ was recorded in the brown sandstone alone treatment. The greatest average volume $\left(30 \mathrm{~cm}^{3}\right)$ was recorded in the brown sandstone with hydroseeding treatment while the least $\left(3 \mathrm{~cm}^{3}\right)$ was recorded in the gray sandstone with hydroseeding and gray sandstone with bark mulch and with hydroseeding treatments. The highest average vigor rating (3.3) was recorded in the brown sandstone alone and gray sandstone with bark mulch treatments while the lowest (2.5) was recorded in the brown sandstone with bark mulch and with hydroseeding, gray sandstone with hydroseeding, and gray sandstone with bark mulch and with hydroseeding treatments. Species survival, height, diameter, and volume for the length of the study can be seen in Figures 3-6a through 3-6d. The good survival of sugar maple in this study is somewhat surprising since it 
prefers shaded and moist environments, neither of which are found on this site. As the trees continue to grow and a canopy forms, sugar maple would be expected to show increased performance as the conditions are more favorable to growth for this species.

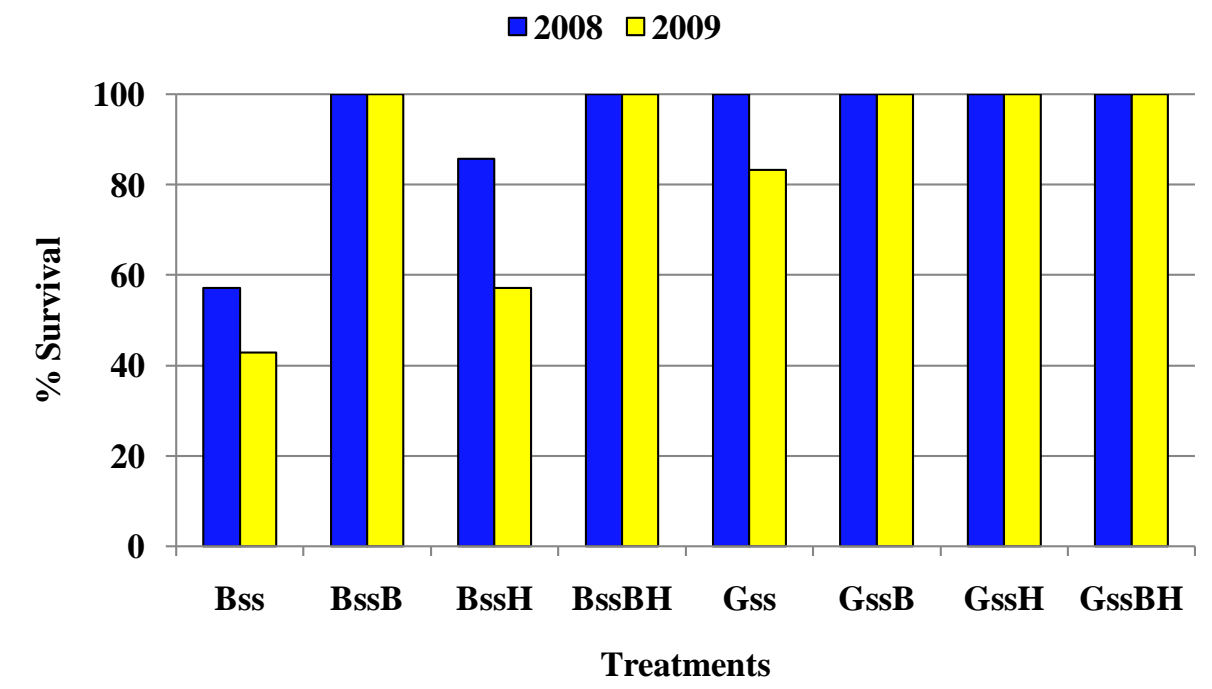

Figure 3-6a. Average survival of sugar maple for two growing seasons in eight soil treatment combinations at ICG Eastern, LLC's Birch River Operation in Webster County, WV

$\square 2007 \square 2008 \square 2009$

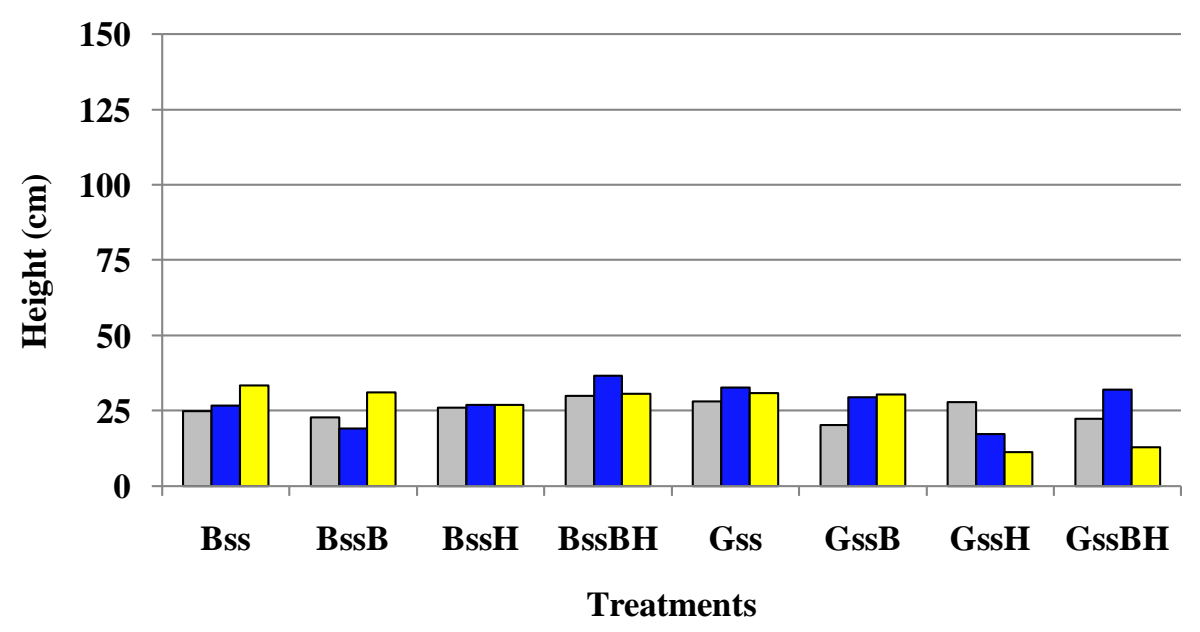

Figure 3-6b. Average height of sugar maple for three growing seasons in eight soil treatment combinations at ICG Eastern, LLC's Birch River Operation in Webster County, WV 


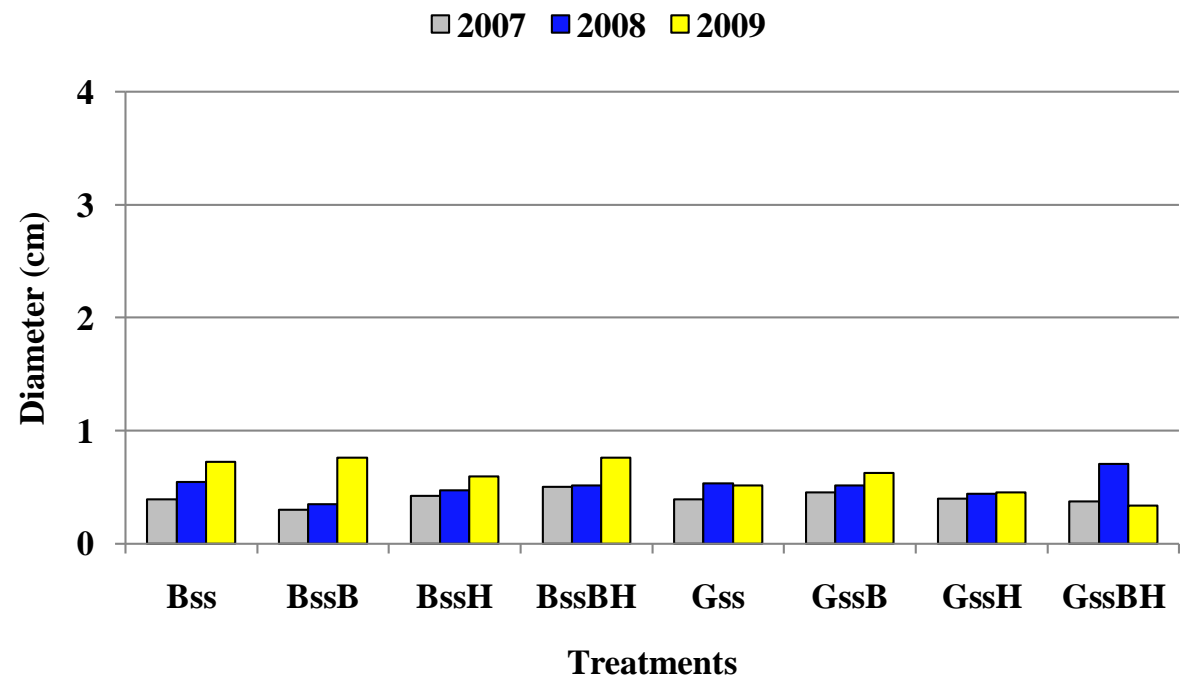

Figure 3-6c. Average diameter of sugar maple for three growing seasons in eight soil treatment combinations at ICG Eastern, LLC's Birch River Operation in Webster County, WV

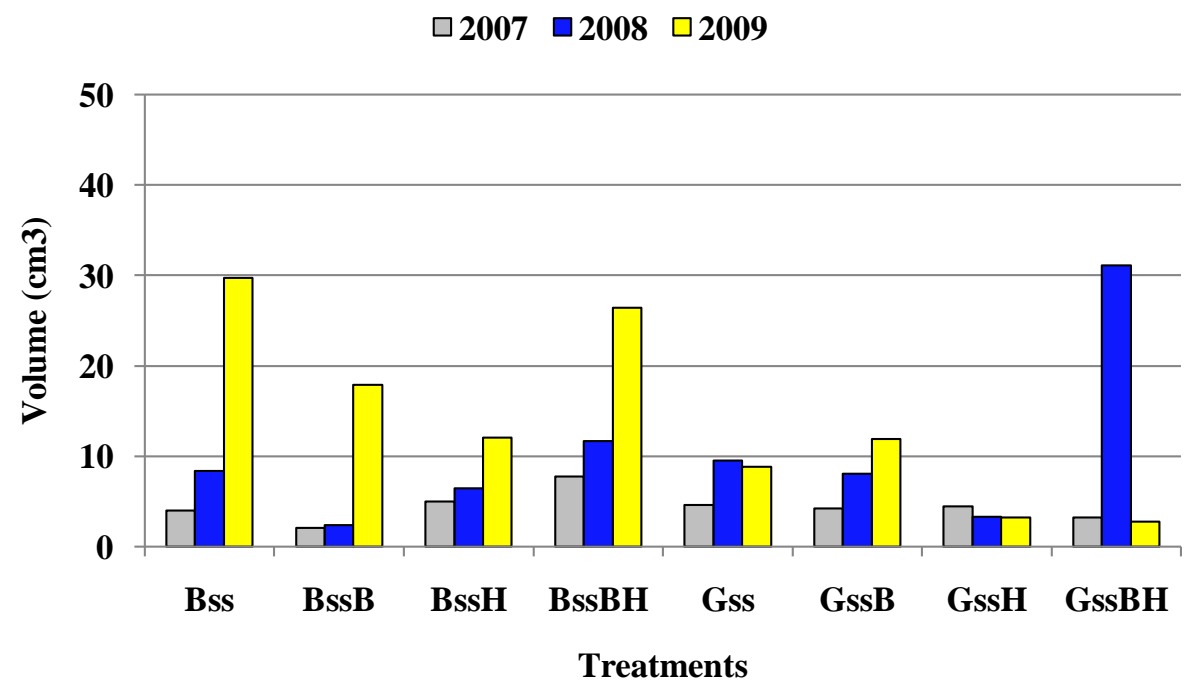

Figure 3-6d. Average volume of sugar maple for three growing seasons in eight soil treatment combinations at ICG Eastern, LLC's Birch River Operation in Webster County, WV

Sycamore had the third lowest average survival across the eight soil treatment combinations at $41 \%$ with an average volume of $71 \mathrm{~cm}^{3}$ and a good to very good vigor rating of 4.3. The highest average survival $(75 \%)$ was recorded in the brown sandstone alone treatment while the lowest $(0 \%)$ was recorded in the gray sandstone with hydroseeding treatment. The greatest average volume $\left(102 \mathrm{~cm}^{3}\right)$ was recorded in the gray sandstone with bark mulch and with hydroseeding treatment while the least $\left(23 \mathrm{~m}^{3}\right)$ was recorded in the gray sandstone alone 
treatment. The highest average vigor rating (5.0) was recorded in the brown sandstone with bark mulch and with hydroseeding and gray sandstone with bark mulch and with hydroseeding treatments while the lowest (3.0) was recorded in the gray sandstone alone treatment. Species survival, height, diameter, and volume for the length of the study can be seen in Figures 3-7a through 3-7d. Its lower survival and slower growth on this site matches its intolerance of coarsetextured, dry mine soils and as the rocky soils mature and as the tree canopy forms, sycamore could show increases as the site becomes more favorable for growth.

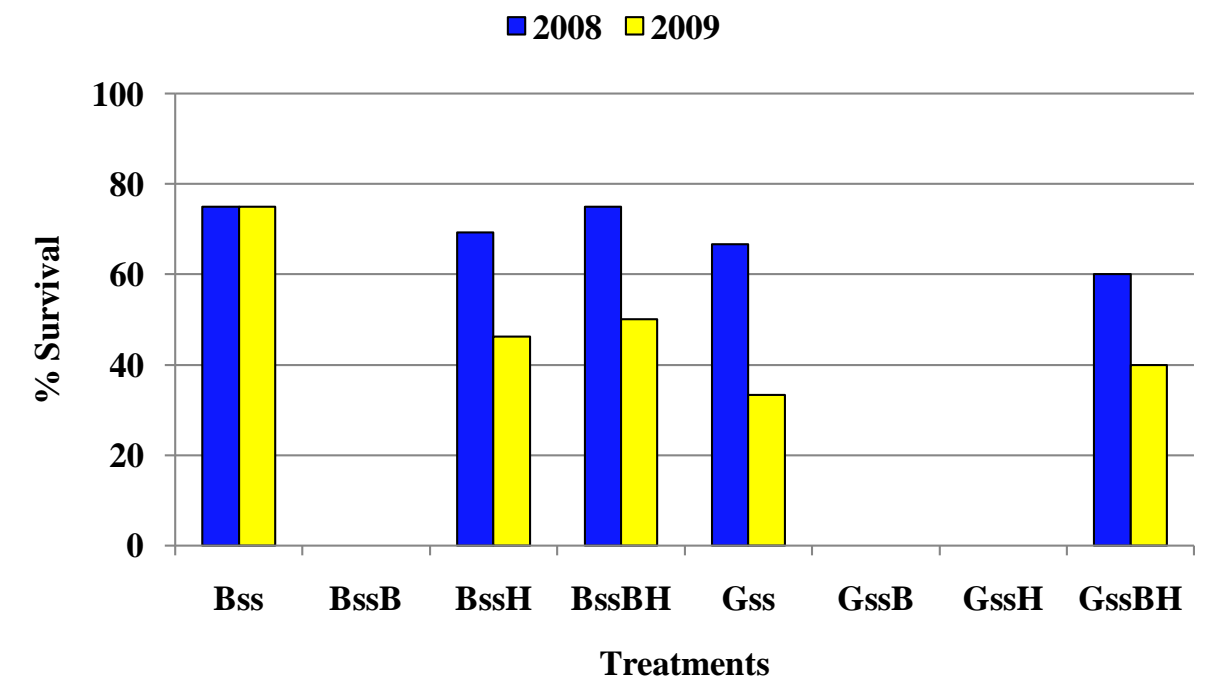

Figure 3-7a. Average survival of sycamore for two growing seasons in eight soil treatment combinations at ICG Eastern, LLC's Birch River Operation in Webster County, WV 


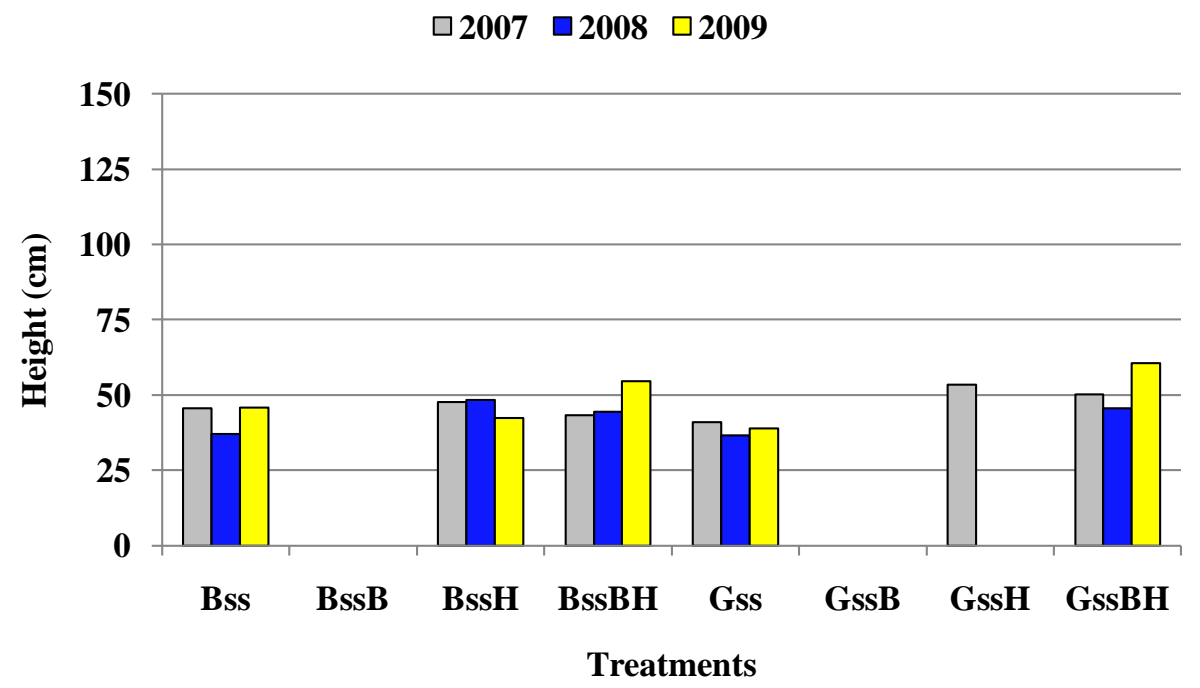

Figure 3-7b. Average height of sycamore for three growing seasons in eight soil treatment combinations at ICG Eastern, LLC's Birch River Operation in Webster County, WV

$\square 2007 \square 2008 \square 2009$

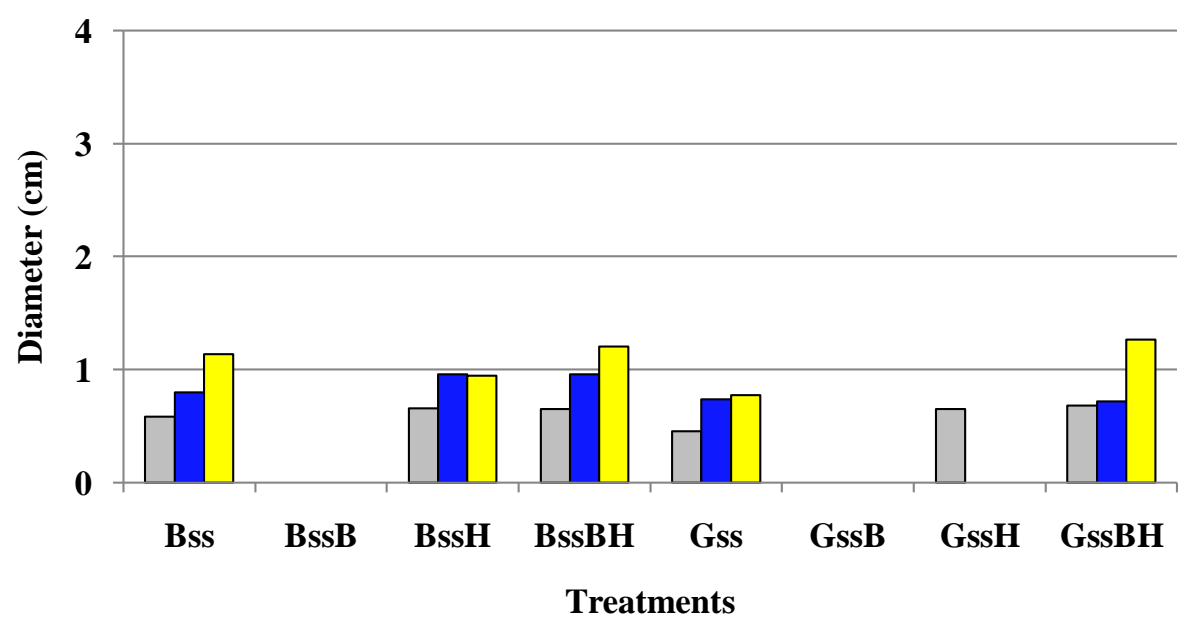

Figure 3-7c. Average diameter of sycamore for three growing seasons in eight soil treatment combinations at ICG Eastern, LLC's Birch River Operation in Webster County, WV 


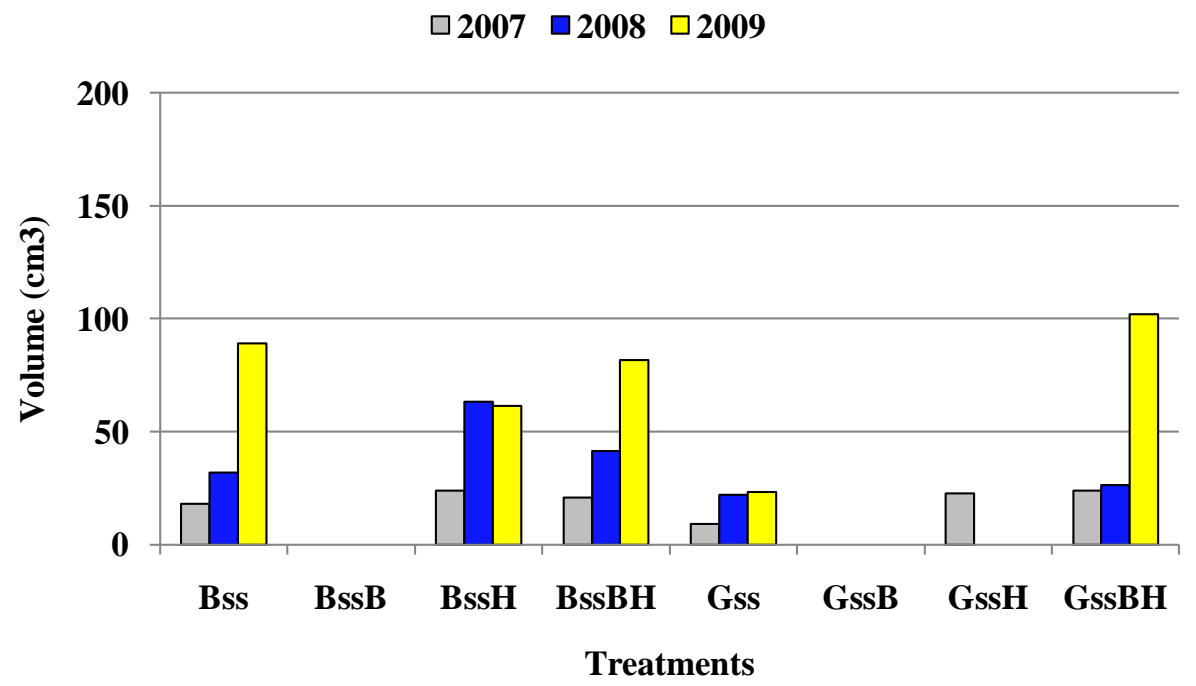

Figure 3-7d. Average volume of sycamore for three growing seasons in eight soil treatment combinations at ICG Eastern, LLC's Birch River Operation in Webster County, WV

Tulip poplar had the fourth lowest average survival across the eight soil treatment combinations at $73 \%$ with an average volume of $319 \mathrm{~cm}^{3}$ and a good to very good vigor rating of 4.4. The highest average survival $(100 \%)$ was recorded in the gray sandstone alone, gray sandstone with bark mulch, and gray sandstone with bark mulch and with hydroseeding treatments while the lowest $(33 \%)$ was recorded in the gray sandstone with hydroseeding treatment. The greatest average volume $\left(963 \mathrm{~cm}^{3}\right)$ was recorded in the brown sandstone with bark mulch treatment while the least $\left(56 \mathrm{~cm}^{3}\right)$ was recorded in the gray sandstone alone treatment. The highest average vigor rating (5.0) was recorded in the brown sandstone with bark mulch treatment while the lowest (3.6) was recorded in the gray sandstone alone treatment. Species survival, height, diameter, and volume for the length of the study can be seen in Figures 3-8a through 3-8d. Its performance in this study shows that the bark mulch treatment helped in producing a much greater volume than in treatments without bark mulch. The lower volume in the brown and gray sandstone with bark mulch and with hydroseeding as compared to the brown 
and gray sandstone with bark mulch could show that tulip poplar is experiencing competition with herbaceous ground covers which are hampering growth.

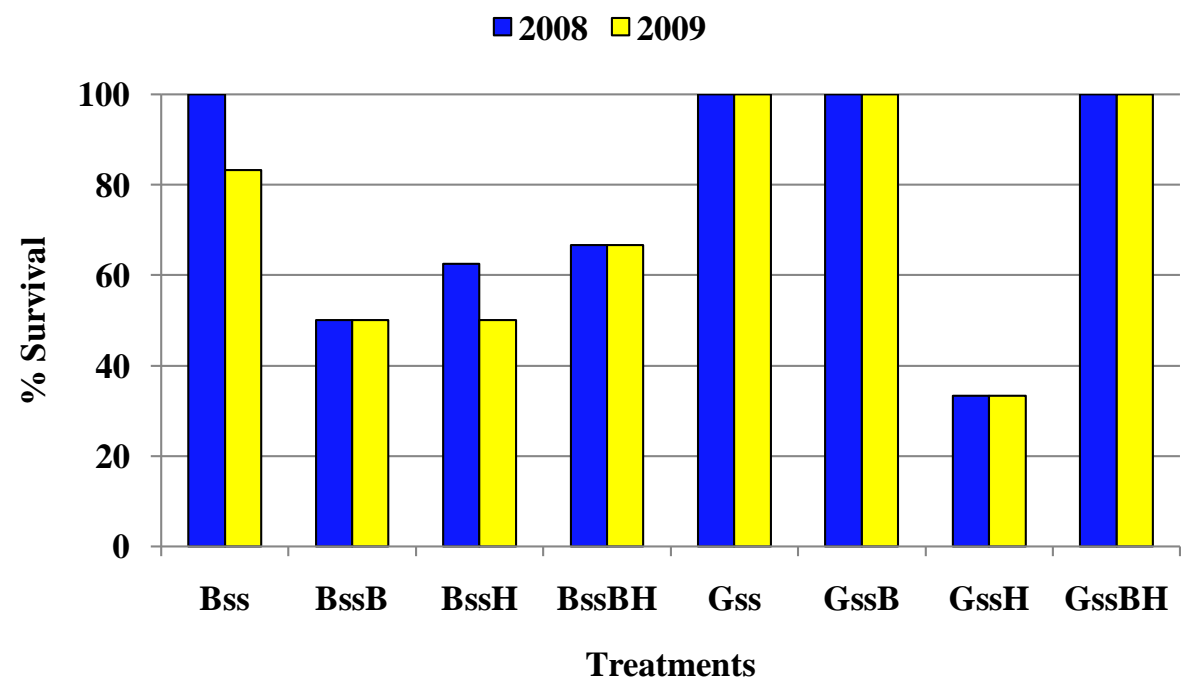

Figure 3-8a. Average survival of tulip poplar for two growing seasons in eight soil treatment combinations at ICG Eastern, LLC's Birch River Operation in Webster County, WV

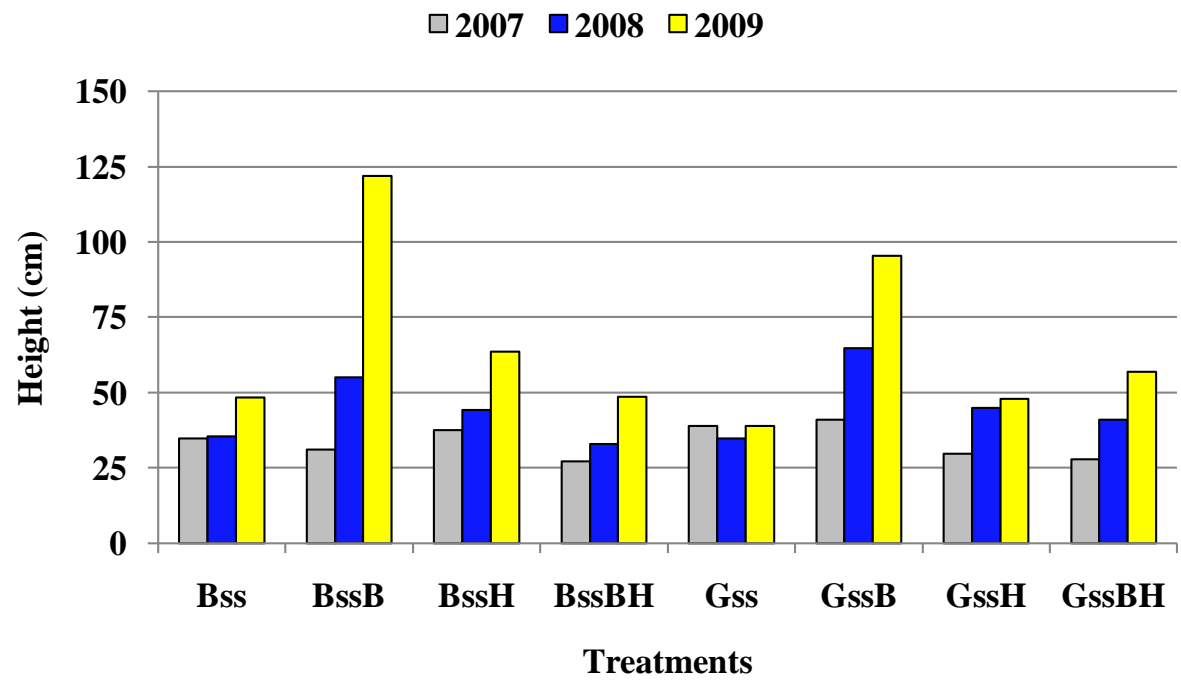

Figure 3-8b. Average height of tulip poplar for three growing seasons in eight soil treatment combinations at ICG Eastern, LLC's Birch River Operation in Webster County, WV 


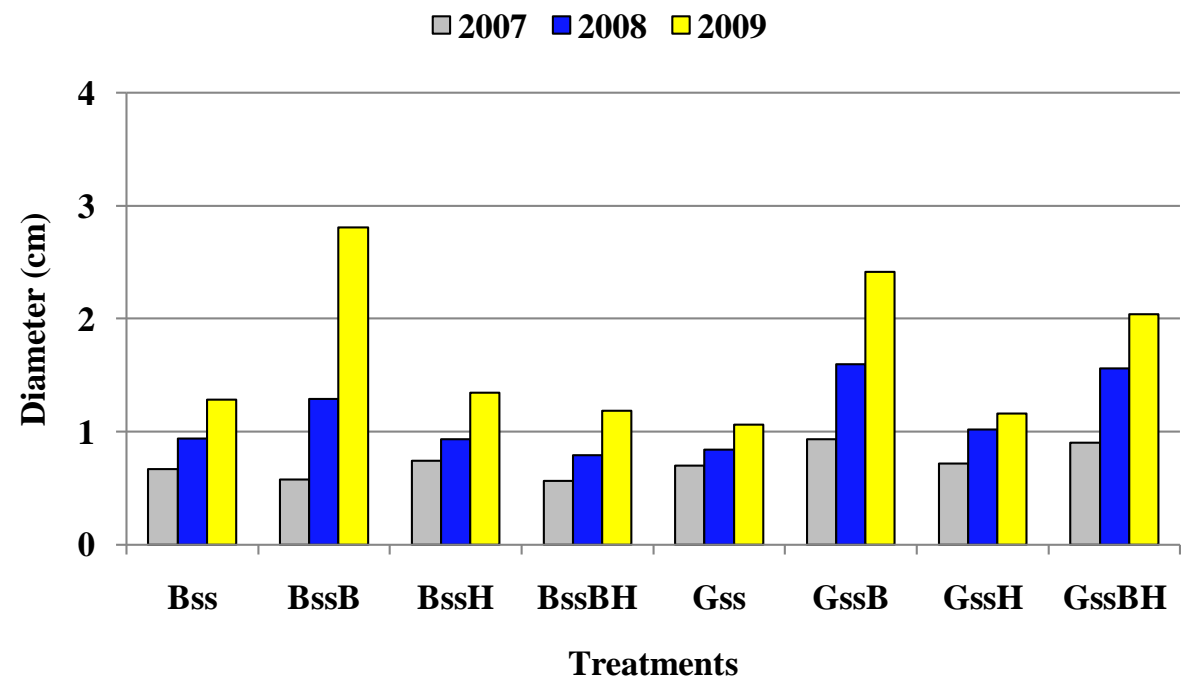

Figure 3-8c. Average diameter of tulip poplar for three growing seasons in eight soil treatment combinations at ICG Eastern, LLC's Birch River Operation in Webster County, WV

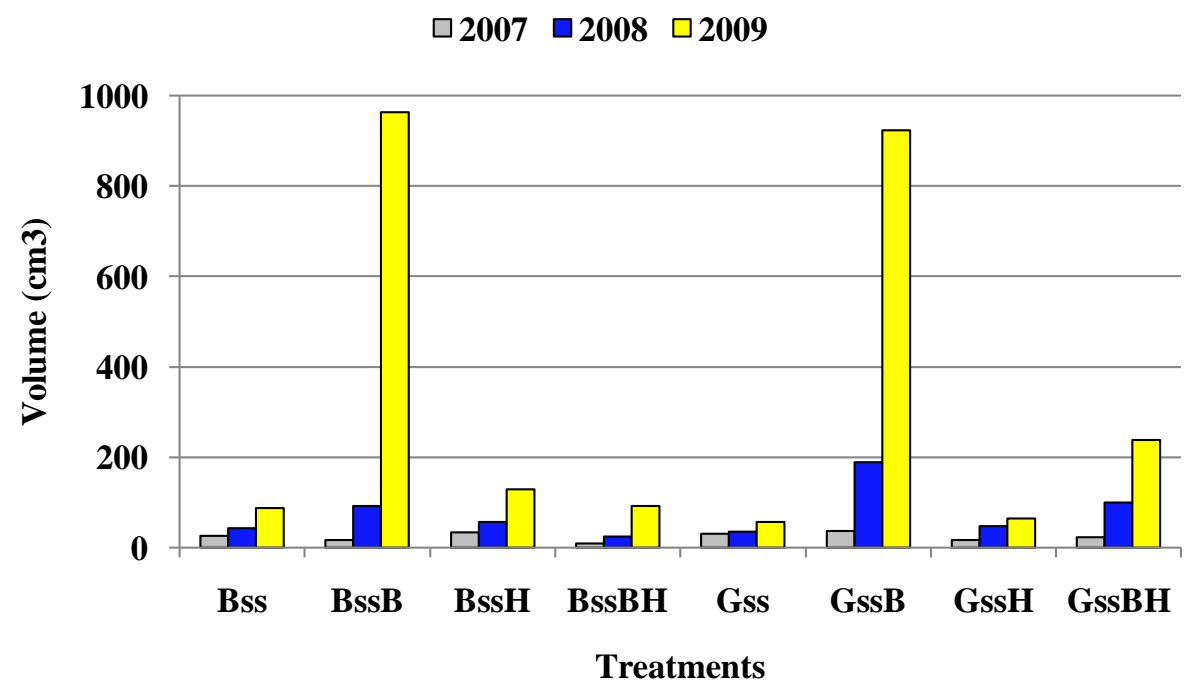

Figure 3-8d. Average volume of tulip poplar for three growing seasons in eight soil treatment combinations at ICG Eastern, LLC's Birch River Operation in Webster County, WV

White ash had the fifth lowest average survival across the eight soil treatment combinations at $75 \%$ with an average volume of $99 \mathrm{~cm}^{3}$ and a good to very good vigor rating of 4.7. The highest average survival (100\%) was recorded in the brown sandstone with bark mulch, brown sandstone with bark mulch and with hydroseeding, and gray sandstone with bark mulch and with hydroseeding treatments while the lowest $(0 \%)$ was recorded in the gray sandstone with hydroseeding treatment. The greatest average volume $\left(180 \mathrm{~cm}^{3}\right)$ was recorded in the gray 
sandstone with bark mulch treatment while the least $\left(36 \mathrm{~cm}^{3}\right)$ was recorded in the gray sandstone with bark mulch and with hydroseeding. The highest average vigor rating (5.0) was recorded in the brown sandstone with bark mulch, brown sandstone with bark mulch and with hydroseeding, and gray sandstone with bark mulch and with hydroseeding treatments while the lowest (4.0) was recorded in the gray sandstone alone treatment. Species survival, height, diameter, and volume for the length of the study can be seen in Figures 3-9a through 3-9d. Skousen et al. (2009) found white ash to have exceptional survival and growth on mine soils, and white ash also performed well in this study as other reports by Zeleznik and Skousen (1996) and Skousen et al. (2006). The addition of bark mulch increased volume in the gray sandstone substrate making it comparable to the brown sandstone treatment combinations. Increases in volume from 2008 to 2009 were exceptional for all the brown sandstone treatments and for the gray sandstone with bark (Figure 3-9d).

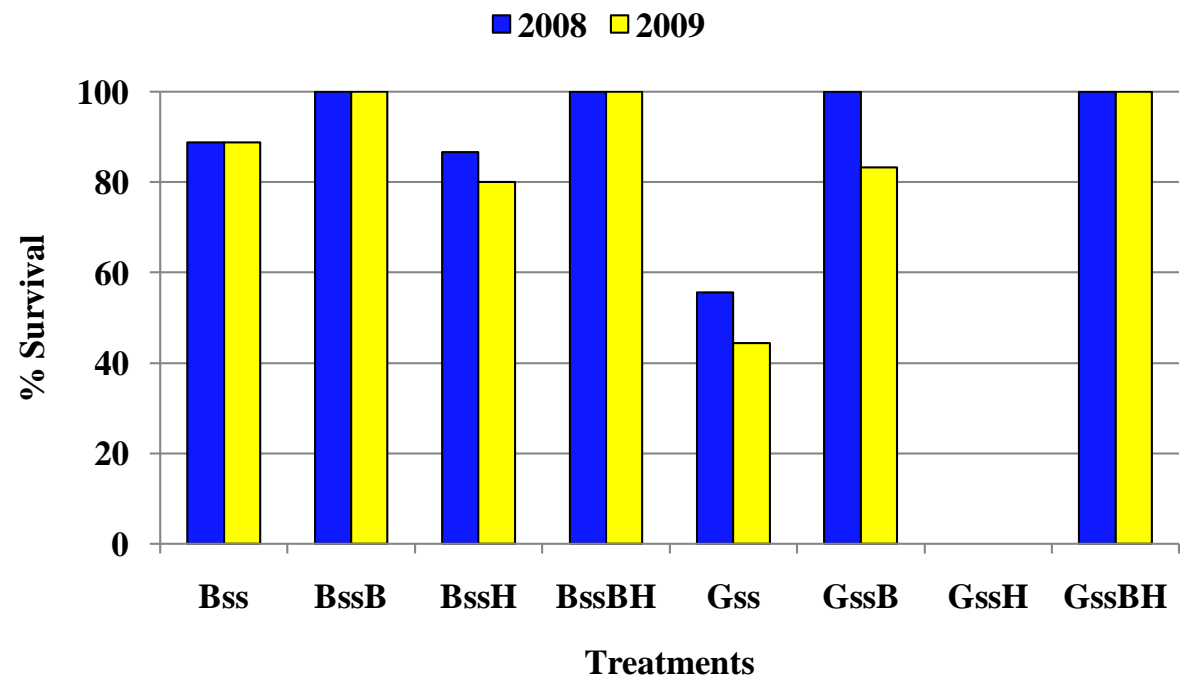

Figure 3-9a. Average survival of white ash for two growing seasons in eight soil treatment combinations at ICG Eastern, LLC's Birch River Operation in Webster County, WV 


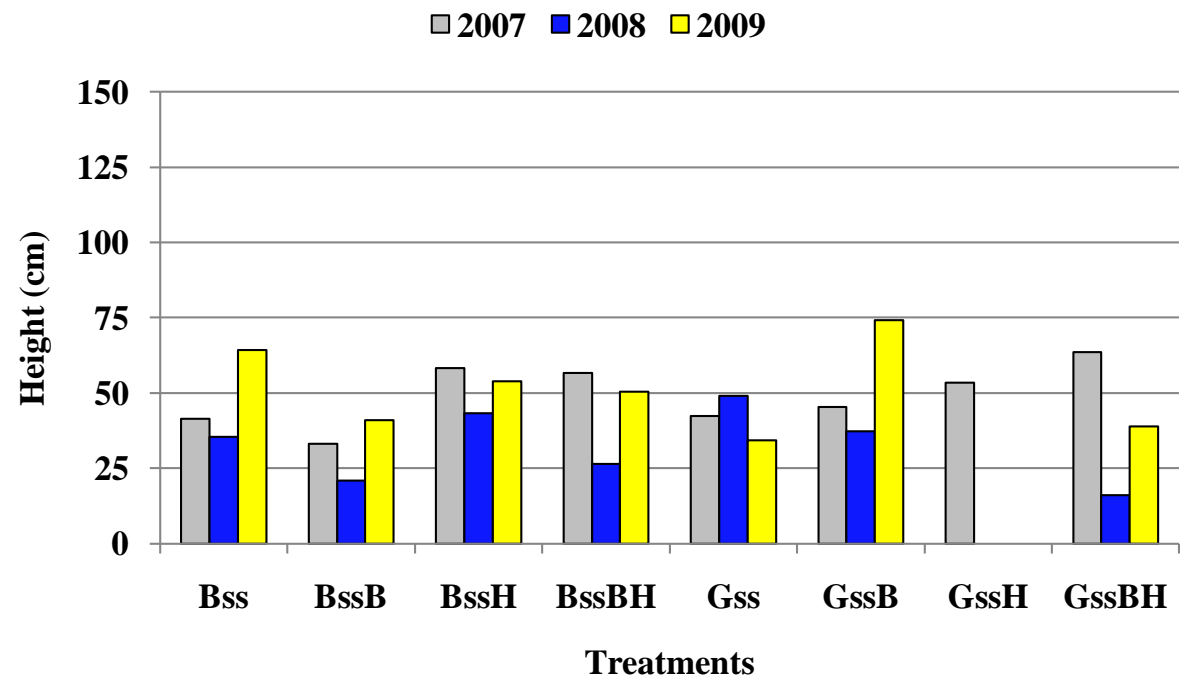

Figure 3-9b. Average height of white ash for three growing seasons in eight soil treatment combinations at ICG Eastern, LLC's Birch River Operation in Webster County, WV

$\square 2007 \square 2008 \square 2009$

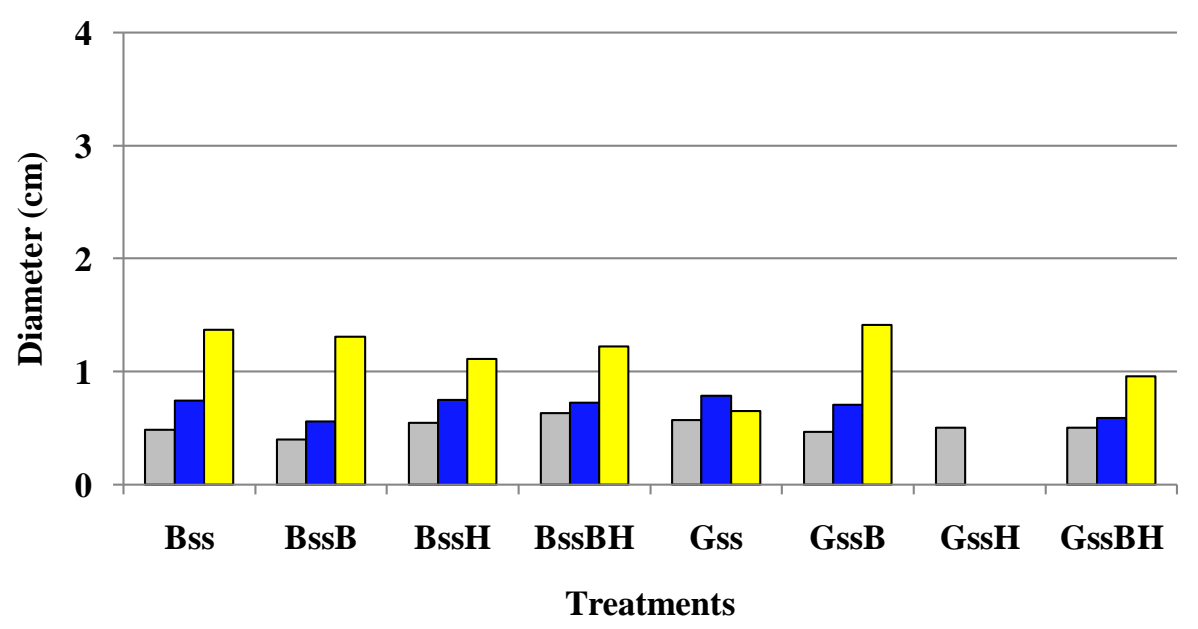

Figure 3-9c. Average diameter of white ash for three growing seasons in eight soil treatment combinations at ICG Eastern, LLC's Birch River Operation in Webster County, WV 


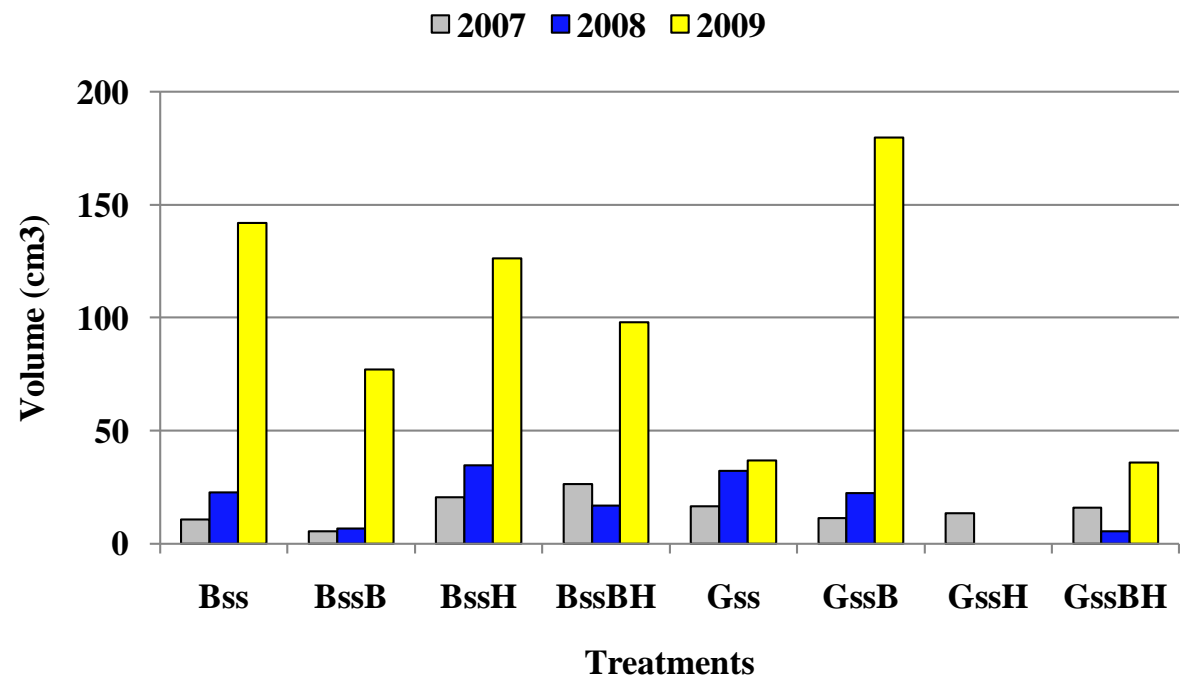

Figure 3-9d. Average volume of white ash for three growing seasons in eight soil treatment combinations at ICG Eastern, LLC's Birch River Operation in Webster County, WV

White oak had the third best average survival across the eight soil treatment combinations at $83 \%$ with an average volume of $44 \mathrm{~cm}^{3}$ and a moderate to good vigor rating of 3.9. The highest average survival (100\%) was recorded in the brown sandstone alone, brown sandstone with bark mulch, brown sandstone with bark mulch and with hydroseeding, and gray sandstone with bark mulch and with hydroseeding while the lowest $(50 \%)$ was recorded in the gray sandstone with bark mulch treatment. The greatest average volume $\left(159 \mathrm{~cm}^{3}\right)$ was recorded in the gray sandstone with bark mulch and with hydroseeding treatment while the least $\left(67 \mathrm{~cm}^{3}\right)$ was recorded in the brown sandstone with hydroseeding treatment. The highest average vigor rating (5.0) was recorded in the gray sandstone with bark mulch and with hydroseeding treatment while the lowest (2.5) was recorded in the gray sandstone alone treatment. Species survival, height, diameter, and volume for the length of the study can be seen in Figures 3-10a through 310d. Due to white oak being a slow growing species, as mentioned in Chapter 1, the lower volume recorded in this study was expected and as trees become established their volume would be expected to be similar to other species that grow to dominate forest canopies. It is noteworthy 
that volume increased more so on the gray sandstone with bark and with hydroseeding than any other treatment.

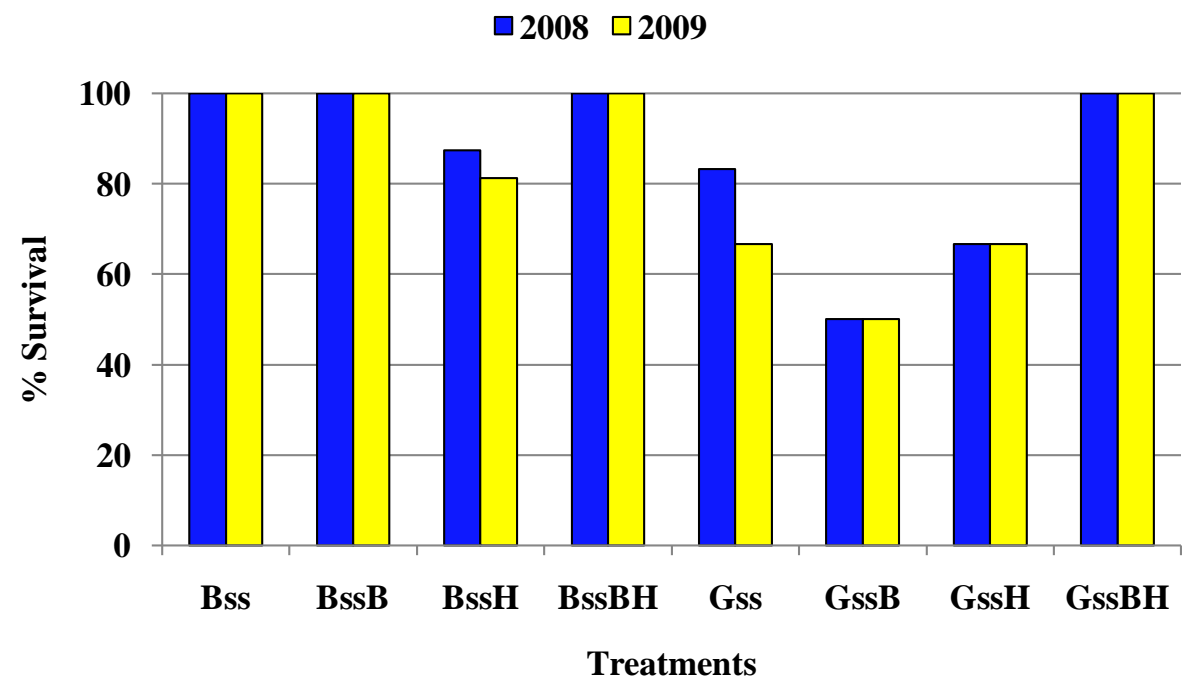

Figure 3-10a. Average survival of white oak for two growing seasons in eight soil treatment combinations at ICG Eastern, LLC's Birch River Operation in Webster County, WV

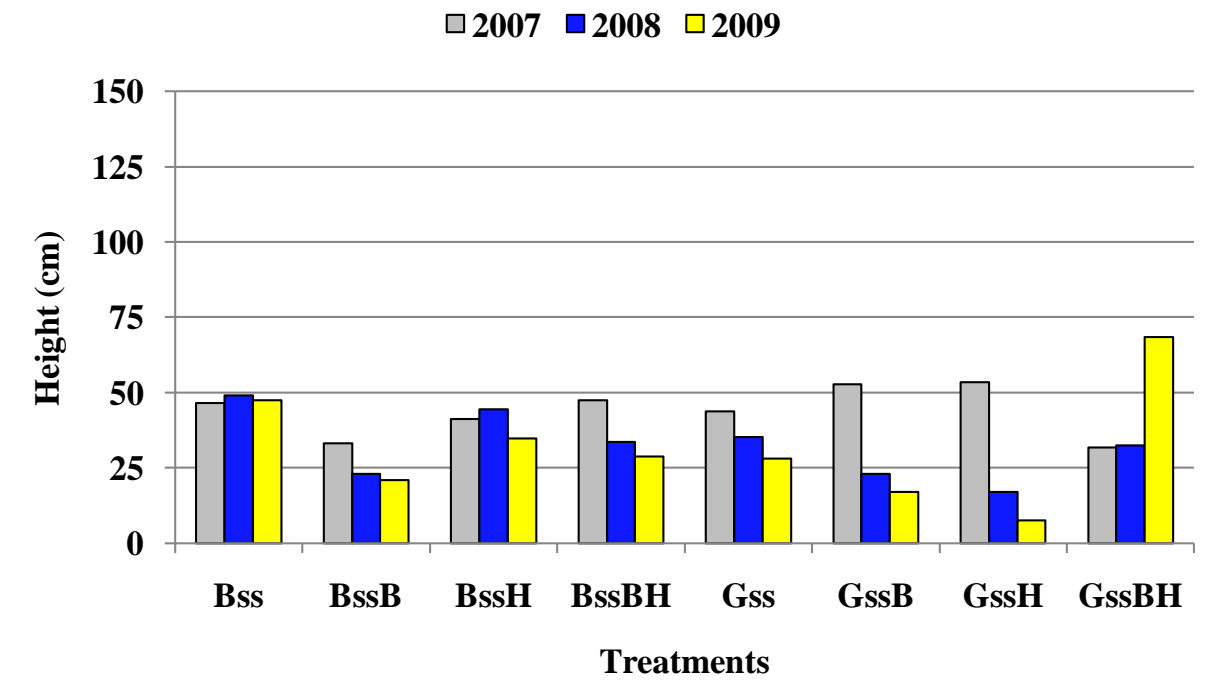

Figure 3-10b. Average height of white oak for three growing seasons in eight soil treatment combinations at ICG Eastern, LLC's Birch River Operation in Webster County, WV 


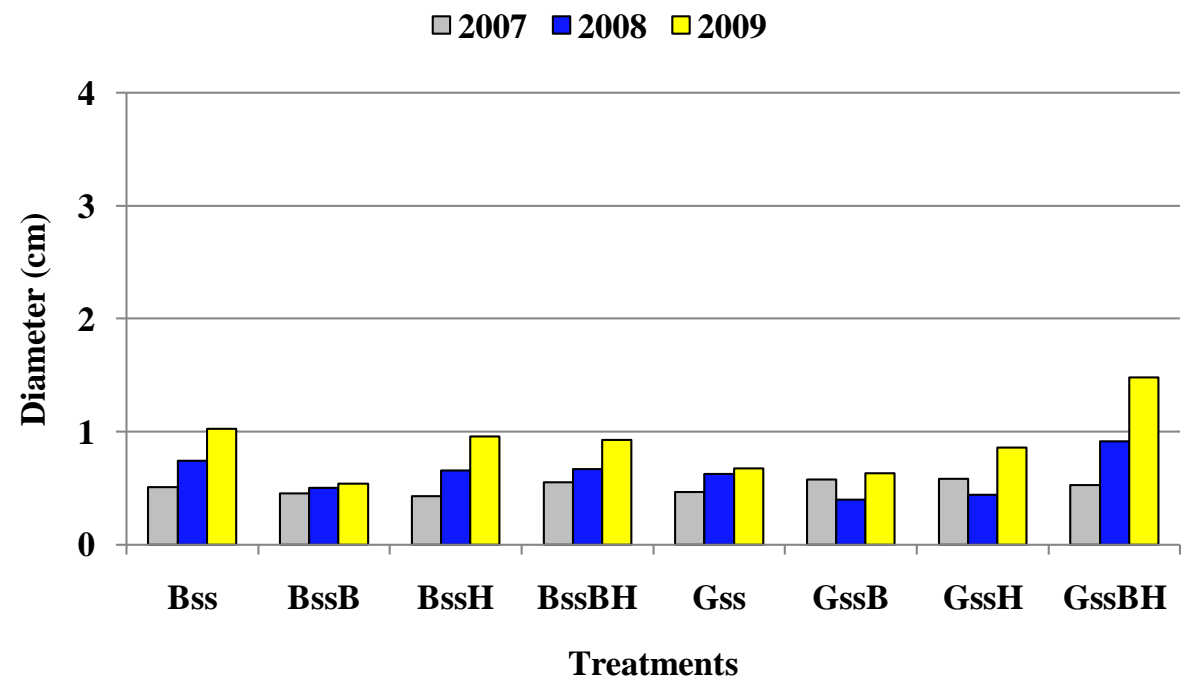

Figure 3-10c. Average diameter of white oak for three growing seasons in eight soil treatment combinations at ICG Eastern, LLC's Birch River Operation in Webster County, WV

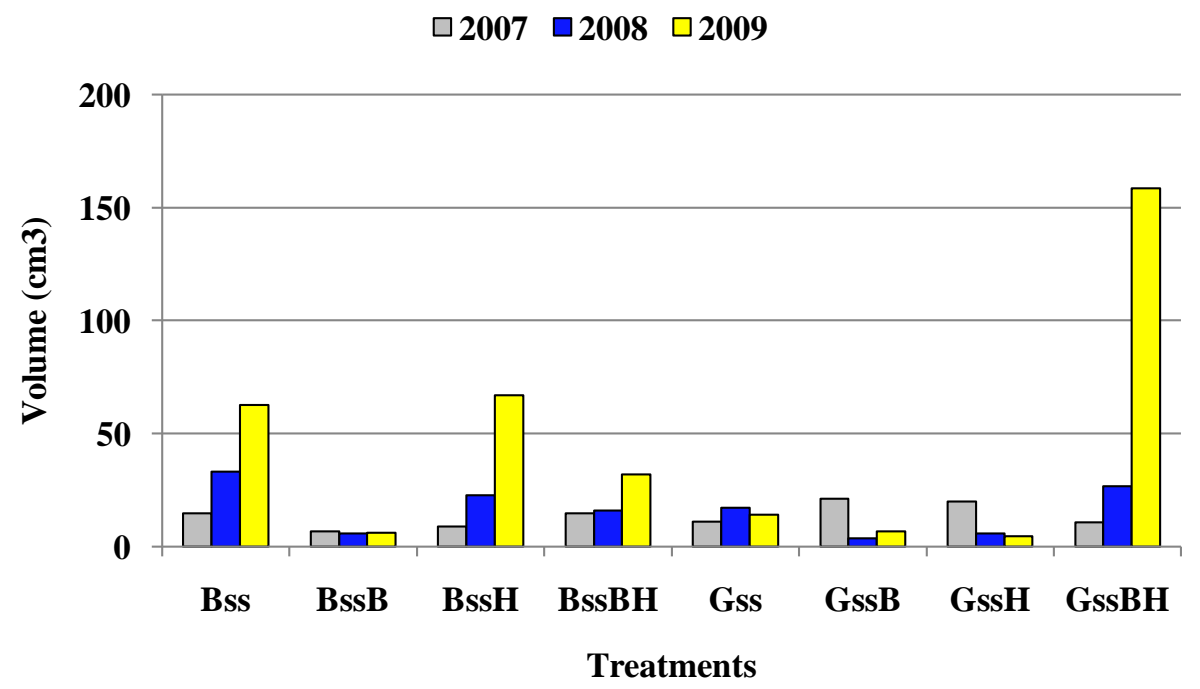

Figure 3-10d. Average volume of white oak for three growing seasons in eight soil treatment combinations at ICG Eastern, LLC's Birch River Operation in Webster County, WV

White pine had the sixth highest average survival across the eight soil treatment combinations at $78 \%$ with an average volume of $82 \mathrm{~cm}^{3}$ and a good to very good vigor rating of 4.8. The highest average survival $(100 \%)$ was recorded in the brown sandstone alone and gray sandstone with bark mulch and with hydroseeding treatments while the lowest $(50 \%)$ was recorded in the brown sandstone with bark mulch and with hydroseeding and gray sandstone with bark mulch treatments. The greatest average volume $\left(189 \mathrm{~cm}^{3}\right)$ was recorded in the brown 
sandstone alone treatment while the least $\left(23 \mathrm{~cm}^{3}\right)$ was recorded in the gray sandstone alone treatment. The highest average vigor rating (5.0) was recorded in the brown sandstone alone, brown sandstone with bark mulch and with hydroseeding, gray sandstone with bark mulch, and gray sandstone with bark mulch and with hydroseeding while the lowest (4.3) was recorded in the gray sandstone alone treatment. Species survival, height, diameter, and volume for the length of the study can be seen in Figures 3-11a through 3-11d. The performance of white pine in this study is similar to Emerson et al. (2009) who showed white pine to have an average survival of $65 \%$ and an average volume of $58 \mathrm{~cm}^{3}$ after three growing seasons. The addition of hydroseeding in the gray sandstone treatment combinations increased volume making it similar to the results found in the brown sandstone treatment combinations (Figure 3-11d).

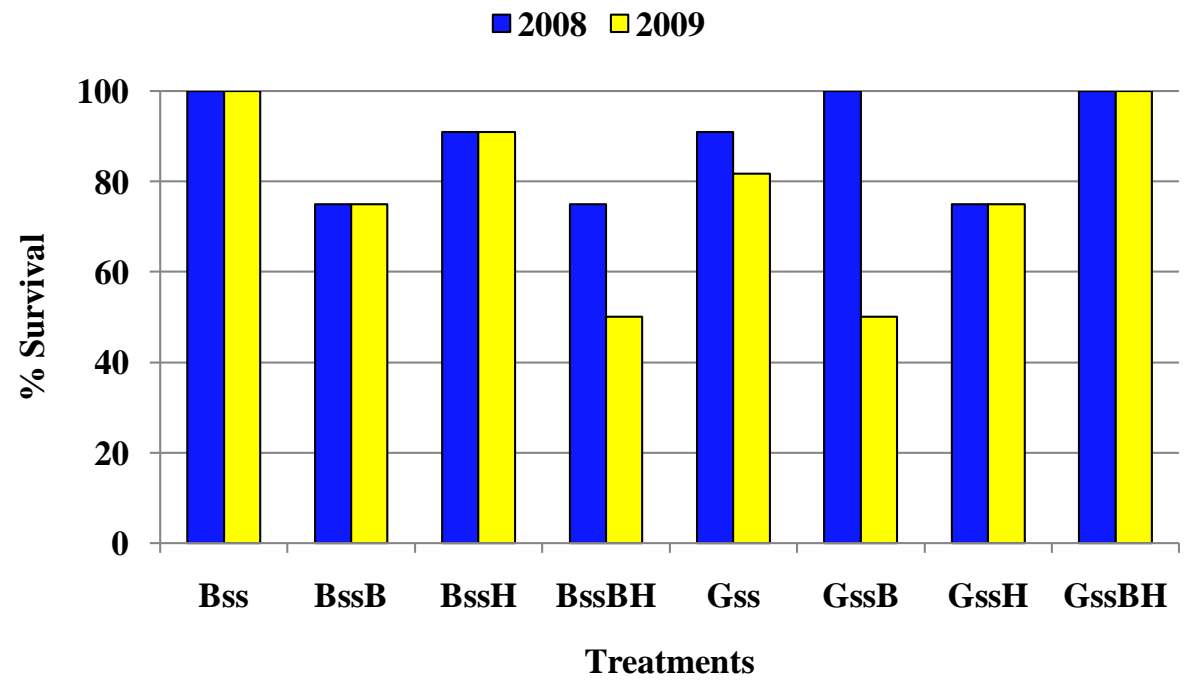

Figure 3-11a. Average survival of white pine for two growing seasons in eight soil treatment combinations at ICG Eastern, LLC's Birch River Operation in Webster County, WV 


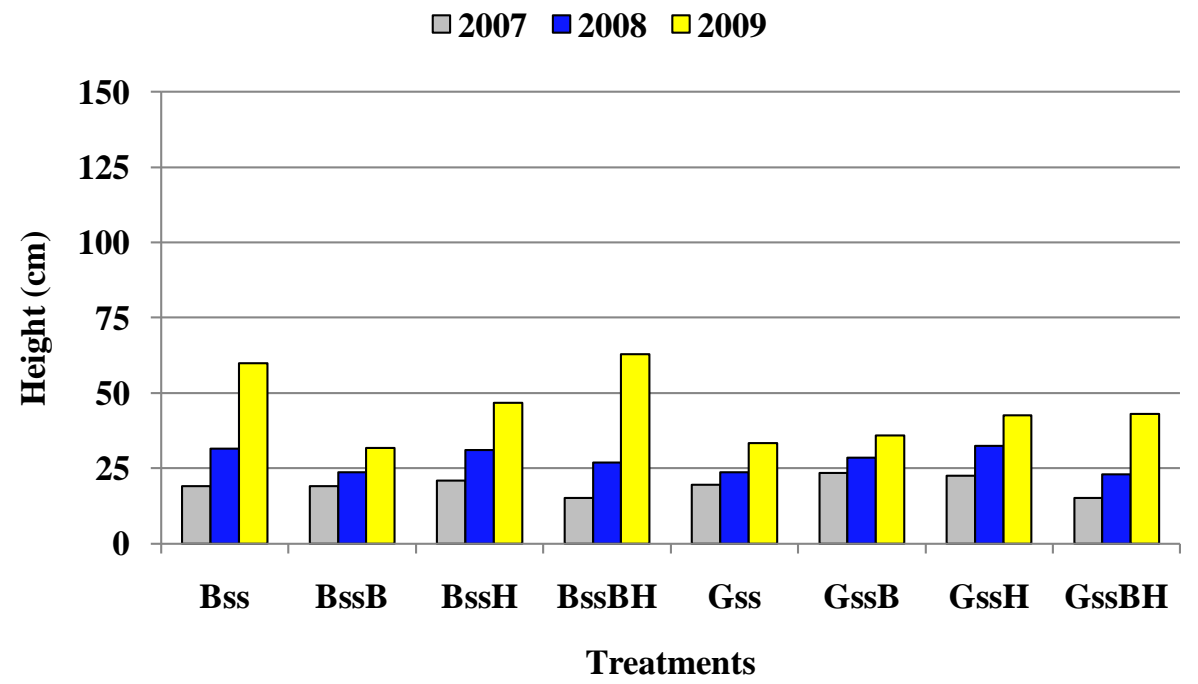

Figure 3-11b. Average height of white pine for three growing seasons in eight soil treatment combinations at ICG Eastern, LLC's Birch River Operation in Webster County, WV

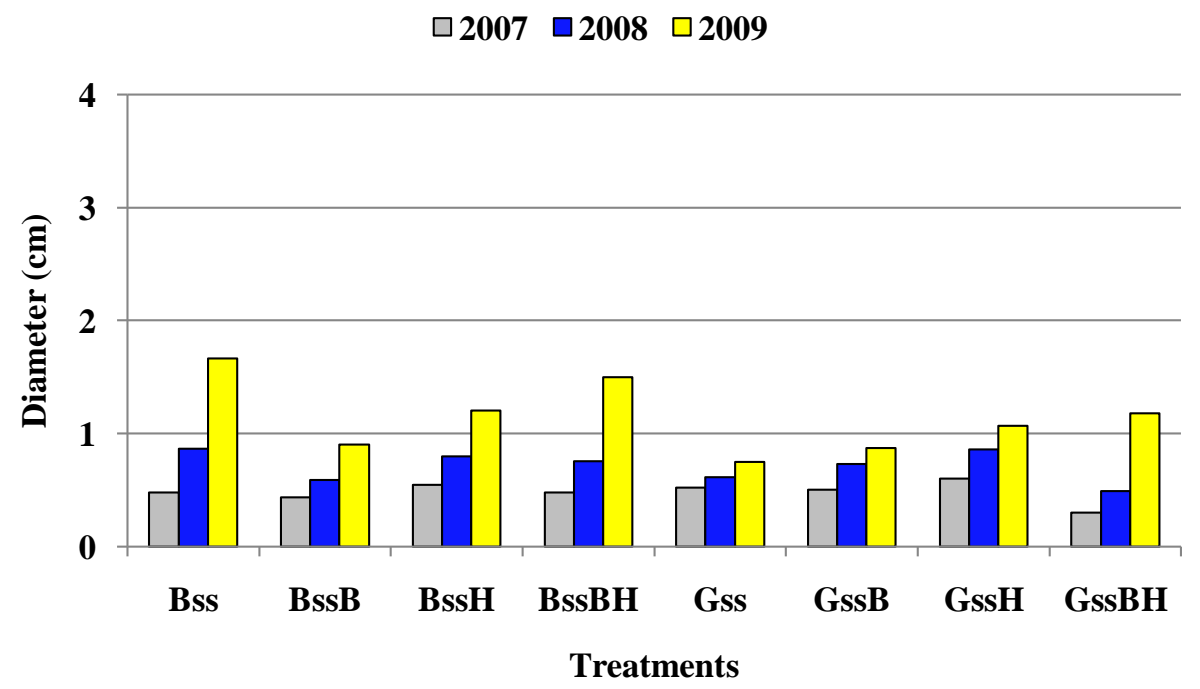

Figure 3-11c. Average diameter of white pine for three growing seasons in eight soil treatment combinations at ICG Eastern, LLC's Birch River Operation in Webster County, WV 


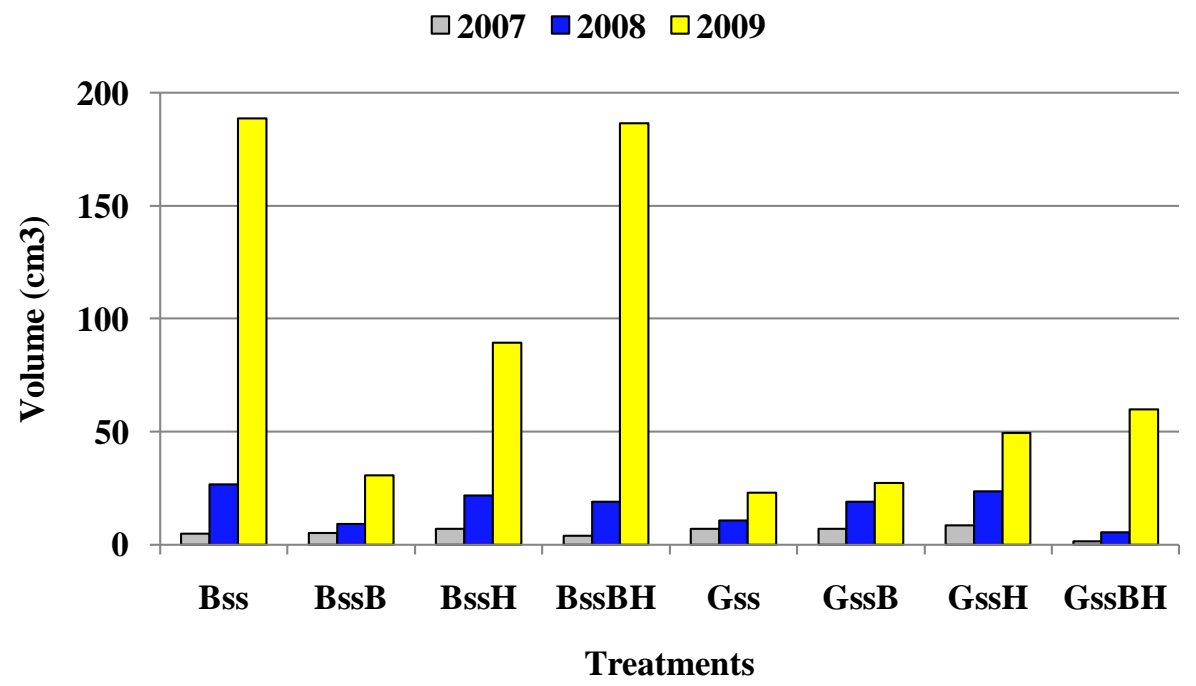

Figure 3-11d. Average volume of white pine for three growing seasons in eight soil treatment combinations at ICG Eastern, LLC's Birch River Operation in Webster County, WV

\section{$\underline{\text { Summary and Conclusions }}$}

Treatments of gray sandstone and treatments with bark mulch had soil $\mathrm{pH}$ levels that were significantly greater than the brown sandstone treatments that did not have bark mulch applied. Bark mulch, which was taken from log landings at sawmills, has ground up limestone from aggregate spread on the site for traction, which gives it a high $\mathrm{pH}$. Therefore, bark mulch has soil and limestone as well as organic matter from trees and mud. Electrical conductivity in treatments that received a bark mulch application was higher than their counterparts. Extractable element concentrations varied greatly across treatments. Overall there were few significant differences among treatments but treatments with bark mulch showed higher concentrations of $\mathrm{Mg}, \mathrm{K}$, and $\mathrm{Ca}$ and lower concentrations of $\mathrm{Zn}$ and $\mathrm{P}$.

Survival among species across all treatment combinations was not significantly different. However, treatments of brown sandstone had significantly greater volume than treatments of gray sandstone. The addition of bark mulch and hydroseeding increased volume but the increases we not significantly greater than the treatments without bark mulch or hydroseeding. Black 
locust was clearly the best performing tree on this site while the other trees showed no significant difference for volume. 


\section{CHAPTER 4. DETERMINATION OF MINE SOIL BULK DENSITY AND COMPARISON OF BULK DENSITY MEASUREMENT TECHNIQUES}

\section{$\underline{\text { Introduction }}$}

Since the late 1970's, mined lands have commonly been reclaimed using smooth grading followed by the establishment of dense grasses and legumes (Groninger et al., 2007). Using this type of reclamation, the land is often reclaimed by heavily compacting soils for stabilization, to minimize erosion, and to provide a good seed bed for pasture and hayland crops. However, in the early 1990's land owners began to show an increasing interest in reclaiming mined land to forest (Torbert and Burger, 2000). Even though the post mining land use chosen for the land was different, the practice of heavily compacting the soils was still being done. In return, this heavy soil compaction is thought to be the number one problem associated with sites being reclaimed with trees on post-SMCRA mine lands (Larson and Vimmerstedt, 1983). Heavy soil compaction affects the trees mainly by impacting root growth. Compacted soils can lead to an increase in the soil resistance to penetration, poor aeration, slow movement of nutrients and water, and the buildup of toxic gases around the roots (Brady and Weil, 2002). One way to avoid this would be to limit compaction of the surface during the reclamation process. This can be achieved by using low compaction grading of the mine soil during reclamation (Sweigard et al., 2007a). Angel et al. (2006) showed that by minimizing compaction through decreased grading, the height and survival of white oak, eastern white pine, northern red oak, black walnut, and yellow poplar were all significantly greater than in compacted mine soils. Zeleznik and Skousen (1996) found that leaving mine soil unleveled (noncompacted) increased the survival and height of white pine and yellow poplar. Knowing that decreased compaction increases tree growth and survival is important, but being able to quantitatively measure the level of compaction is key to showing the differences in compaction levels. 
Soil compaction can be measured in many ways. The common practice is by measuring soil bulk density. Soil bulk density is defined as the mass of a unit volume of dry soil in which both solids and pore space are included in the volume measurement (Brady and Weil, 2002). Measurement is achieved in one of three ways. The first and most common way of sampling soil bulk density is by collecting an intact soil core of known volume (Blake and Hartge, 1986). A second way is by excavating the soil and then measuring the physical dimension of the excavated cavity using rulers. A third way is by excavating the soil and filling the excavated cavity with a medium of known density such as sand or with a substance such as polyurethane foam in which the volume of the polyurethane foam filling the cavity can be determined. In mine soils, it's often difficult to extract soil by means of a container with a known volume due to the high amount of rock fragments. Thus excavation methods are more commonly used to determine bulk density in mine soils. A radiation technique using a moisture-density gauge can also be used for bulk density determination (American Society for Testing and Materials, 1999). However, a certified technician is required to conduct the readings due to the ${ }^{137} \mathrm{Cs}$ found in the moisture-density gauge.

\section{Objectives}

a. Determine soil bulk density in mine soils composed of weathered brown sandstone and unweathered gray sandstone and to compare these to unmined native forest.

b. Compare four soil bulk density determination methods and evaluate their in-field efficiency.

\section{Methods and Materials}

This study was conducted at Catenary Coal's Samples mine $\left(38^{\circ} 26^{\prime} 27^{\prime \prime} \mathrm{N}, 80^{\circ} 36^{\prime} 33^{\prime \prime}\right.$ W) near the town of Eskdale, in Kanawha County, West Virginia. Five substrates were chosen 
for the bulk density determination. Four of the substrates were reforestation demonstration plots and the fifth was adjacent unmined native forest (Table 4-1). In January 2005, Catenary Coal constructed the demonstration plots consisting of weathered brown sandstone to a depth of $1.5 \mathrm{~m}$ and unweathered gray sandstone to a depth of $1.5 \mathrm{~m}$. Plots were constructed by end-dumping the overburden material in closely adjacent piles and then one half of each plot was compacted by using a bulldozer to completely cover the surface with tracks while the other half of the plot was graded with only one or two passes of the bulldozer to minimize compaction. The unmined native forest substrate (Dekalb-Pineville-Guyandotte association) was located adjacent to the demonstration plots on the permitted area.

Table 4-1. Substrates used for bulk density determination at Catenary Coal's Samples mine operation in Mine in Kanawha County, West Virginia

\begin{tabular}{ll}
\hline Substrate & Abbreviation \\
\hline $1.5 \mathrm{~m}$ weathered brown sandstone compacted & $5 \mathrm{~B}-\mathrm{C}$ \\
$1.5 \mathrm{~m}$ weathered brown sandstone noncompacted & $5 \mathrm{~B}-\mathrm{NC}$ \\
$1.5 \mathrm{~m}$ unweathered gray sandstone compacted & $5 \mathrm{G}-\mathrm{C}$ \\
$1.5 \mathrm{~m}$ unweathered gray sandstone noncompacted & $5 \mathrm{G}-\mathrm{NC}$ \\
Unmined native forest & $\mathrm{UNF}$ \\
\hline
\end{tabular}

In July 2009, three excavation techniques (polyurethane foam, frame apparatus, and sandcone) and one radiation technique were used for determining soil bulk density. For the polyurethane foam technique, a hole with a square surface area of about $225 \mathrm{~cm}^{2}(15 \mathrm{~cm} \times 15$ $\mathrm{cm}$ ) and depth of approximately $15 \mathrm{~cm}$ was excavated using a hand trowel and the substrate material was collected and saved for weight determination. The excavated area was then filled with polyurethane foam (Mueller and Hamilton, 1992). The foam was applied by starting at the deepest part of the hole and working upwards in a circular fashion leaving a small excess when finished. A piece of cardboard was then placed over the hole and weighted to push the foam into crevices in the hole. After curing and hardening over night, the foam was trimmed off flush with the soil surface, carefully removed, and excess soil was brushed and picked from the surface of 
the foam form. The foam form was labeled and returned to the laboratory where its volume was measured by water displacement. The excavated soil was air dried for a period of seven days in the West Virginia University (WVU) green house and then weighed to determine the mass of each sample.

For the sand-cone technique, a metal template was placed on the soil surface and soil was excavated in a $15-\mathrm{cm}$ diameter hole to a depth of $15 \mathrm{~cm}$ through the center of the template (Blake and Hartge, 1986). The hole was then filled with sand and the weight of the sand used to fill the hole was recorded and later used to calculate the volume of the hole using the density of the sand used (sand density $=1.43 \mathrm{~g} \mathrm{~cm}^{3}$ ). The excavated soil was air dried for a period of seven days in the WVU green house and then weighed to determine the mass of each sample.

For the frame apparatus method, a wooden frame measuring $1225 \mathrm{~cm}^{2}(35 \mathrm{~cm}$ by $35 \mathrm{~cm}$ square) with a plexi-glass cover plate, containing 40 evenly placed holes, was placed on the soil surface and secured with four metal rods (Grossman and Reinsch, 2002). The distance to the soil surface from the plastic plate was then measured in the 40 holes. After initial measurements, the plexi-glass plate was removed (the wooden frame being left in place) and the soil was excavated to a depth of about $15 \mathrm{~cm}$. After excavation, the plastic cover plate was replaced and the distance to the bottom of the excavated area to the soil surface was again measured in the 40 holes to determine the volume of soil removed. The differences in height was determined and multiplied by $1000 \mathrm{~cm}^{2}$ to obtain the volume measurement.

$$
\text { Volume }=\left[\sum\left(\mathrm{H}_{1}-\mathrm{H}_{0}\right) / 40\right) \times 1000 \mathrm{~cm}^{2}
$$

Where: $\mathrm{H}_{0}$ equals initial height measurement, $\mathrm{H}_{1}$ equals height measurement after excavation, and $1000 \mathrm{~cm}^{2}$ equals area covered by the frame. The excavated soil was air dried for a period of seven days in the WVU green house and then weighed to determine the mass of each sample. 
The radiation method (American Society for Testing and Materials, 1999) required contracting a private firm to conduct the soil bulk density sampling since a registered nuclear radiation technician must operate the device. The substrate surface was prepared by removing any loose materials that would have prevented adequate contact between the testing device and the substrate. A hole was then formed in the substrate by pounding a $2.5 \mathrm{~cm}$ steel rod approximately $20 \mathrm{~cm}$ into the soil for the insertion of the testing probe. The testing probe was then placed in the hole to a depth of $15 \mathrm{~cm}$ and a one-minute reading was taken at each sampling point. Bulk substrate samples were then collected at the $15 \mathrm{~cm}$ depth by the technician so density calculations could be determined after correction for soil moisture.

Bulk density measurements were taken in each treatment from five randomly located points. The four sampling techniques were conducted from within a $4-\mathrm{m}^{2}$ area at each of the randomly selected locations. Five replications of each technique were conducted in each treatment (five replications and four techniques equaling 20 measurements per treatment for a total $n=100$ ). The in-field efficiency of the techniques used was determined by the amount of time it took to complete each technique in the field. The statistical analysis was performed by a General Linear Model by substrate and technique and Tukey's multiple comparison test was used to determine significant differences at $P<0.05$ level for soil bulk density and in-field efficiency.

\section{$\underline{\text { Results and Discussion }}$}

The bulk density determined with the sand-cone technique was significantly lower than the other three determination techniques, giving results that were 18 to $23 \%$ lower than the other techniques. No significant differences were found among the frame, polyurethane foam, or radiation techniques (Table 4-2). Bulk density measurements by technique ranged from 1.35 to 
$1.76 \mathrm{~g} \mathrm{~cm}^{-3}$. The significantly lower bulk density for the sand-cone technique compared to the others was not expected. Muller and Hamilton (1992) found that there was no significant difference between the sand-cone and polyurethane techniques when compared in two compacted mine soil substrates. However, the polyurethane foam and radiation techniques produced similar results to Page-Dumroese et al. (1999) who found little to no significant difference between the two techniques when compared in a rocky forest soil.

The bulk density in the unmined native forest substrate was significantly lower than the four sandstone substrates and there were no significant differences among the four sandstone substrates (Table 4-2). The unmined native forest substrate had a bulk density that was approximately 38 to $43 \%$ lower than the sandstone substrates.

Bulk density by substrate ranged from 1.05 to $1.84 \mathrm{~g} \mathrm{~cm}^{-3}$. The bulk densities for the four sandstone substrates and the unmined native forest were comparable to other studies conducted on similar sites. Michels et al. (2007) found bulk densities of 1.66 and $1.72 \mathrm{~g} \mathrm{~cm}^{-3}$ in compacted sandstone substrates and 1.60 and $1.61 \mathrm{~g} \mathrm{~cm}^{-3}$ in noncompacted sandstone substrates at a depth of $15 \mathrm{~cm}$. The unmined native forest bulk densities were similar to and slightly lower than PageDumroese et al. (1999) for the polyurethane foam and radiation techniques in which the authors found the bulk densities to be 1.10 and $1.24 \mathrm{~g} \mathrm{~cm}^{-3}$ at $0-10 \mathrm{~cm}$ and 1.11 to $1.21 \mathrm{~g} \mathrm{~cm}^{-3}$ at $10-20$ $\mathrm{cm}$. 
Table 4-2. Soil bulk density and in-field efficiency for four soil bulk density determination techniques in five substrates at Catenary Coal's Samples mine operation in Kanawha County, West Virginia

\begin{tabular}{|c|c|c|c|}
\hline & & Bulk Density & In-field efficiency \\
\hline \multirow[t]{5}{*}{ Technique } & & $\mathrm{g} \mathrm{cm}^{-3}$ & $\mathrm{~s}$ \\
\hline & Frame & $1.69^{\mathrm{a}}$ & $1605^{\mathrm{a}}$ \\
\hline & Polyurethane foam & $1.76^{\mathrm{a}}$ & $612^{\mathrm{c}}$ \\
\hline & Radiation & $1.64^{\mathrm{a}}$ & $345^{\mathrm{d}}$ \\
\hline & Sand-cone & $1.35^{\mathrm{b}}$ & $837^{\mathrm{b}}$ \\
\hline \multicolumn{4}{|l|}{ Substrate } \\
\hline & $5 B-C$ & $1.76^{\mathrm{a}}$ & $1032^{\mathrm{a}}$ \\
\hline & $5 \mathrm{~B}-\mathrm{NC}$ & $1.84^{\mathrm{a}}$ & $939^{\mathrm{ab}}$ \\
\hline & $5 \mathrm{G}-\mathrm{C}$ & $1.72^{\mathrm{a}}$ & $750^{c}$ \\
\hline & $5 \mathrm{G}-\mathrm{NC}$ & $1.70^{\mathrm{a}}$ & $714^{\mathrm{c}}$ \\
\hline & UNF & $1.05^{\mathrm{b}}$ & $816^{\mathrm{bc}}$ \\
\hline \multicolumn{4}{|l|}{ Interactions $^{\dagger}$} \\
\hline & F-5 B-C & $1.92^{\mathrm{ab}}$ & $2016^{\mathrm{a}}$ \\
\hline & F-5B-NC & $1.90^{\mathrm{ab}}$ & $1632^{\mathrm{ab}}$ \\
\hline & F-5G-C & $1.79^{\mathrm{abc}}$ & $1356^{\mathrm{bc}}$ \\
\hline & F-5G-NC & $1.74^{\mathrm{abc}}$ & $1368^{\mathrm{bc}}$ \\
\hline & F-UNF & $1.12^{\mathrm{de}}$ & $1656^{\mathrm{ab}}$ \\
\hline & P-5B-C & $1.97^{\mathrm{a}}$ & $780^{\mathrm{de}}$ \\
\hline & $\mathrm{P}-5 \mathrm{~B}-\mathrm{NC}$ & $1.87^{\mathrm{abc}}$ & $720^{\text {def }}$ \\
\hline & P-5G-C & $2.12^{\mathrm{a}}$ & $516^{\text {efg }}$ \\
\hline & $\mathrm{P}-5 \mathrm{G}-\mathrm{NC}$ & $1.86^{\mathrm{abc}}$ & $468^{\text {efg }}$ \\
\hline & P-UNF & $0.99^{\mathrm{de}}$ & $576^{\text {efg }}$ \\
\hline & $\mathrm{R}-5 \mathrm{~B}-\mathrm{C}$ & $1.78^{\mathrm{abc}}$ & $264^{\mathrm{g}}$ \\
\hline & $\mathrm{R}-5 \mathrm{~B}-\mathrm{NC}$ & $1.82^{\mathrm{abc}}$ & $384^{\text {efg }}$ \\
\hline & $\mathrm{R}-5 \mathrm{G}-\mathrm{C}$ & $1.78^{\mathrm{abc}}$ & $408^{\text {efg }}$ \\
\hline & $\mathrm{R}-5 \mathrm{G}-\mathrm{NC}$ & $1.74^{\mathrm{abc}}$ & $312^{\mathrm{fg}}$ \\
\hline & R-UNF & $1.10^{\mathrm{de}}$ & $360^{\text {efg }}$ \\
\hline & S-5B-C & $1.38^{\text {cde }}$ & $1068^{\mathrm{cd}}$ \\
\hline & S-5B-NC & $1.76^{\mathrm{abc}}$ & $1020^{\mathrm{cd}}$ \\
\hline & S-5G-C & $1.18^{\mathrm{de}}$ & $720^{\operatorname{def}}$ \\
\hline & S-5G-NC & $1.46^{\mathrm{bcd}}$ & $708^{\operatorname{def}}$ \\
\hline & S-UNF & $0.97^{\mathrm{e}}$ & $672^{\text {defg }}$ \\
\hline
\end{tabular}

${ }^{\top} \mathrm{F}-5 \mathrm{~B}-\mathrm{C}=$ frame $1.5 \mathrm{~m}$ brown compacted, P-5B-NC = polyurethane foam $1.5 \mathrm{~m}$ brown noncompacted, $\mathrm{R}-5 \mathrm{G}-\mathrm{C}=$ radiation $1.5 \mathrm{~m}$ gray compacted, $\mathrm{S}-\mathrm{UNF}=$ sand-cone unmined native forest

Significantly different in-field efficiency times were recorded for each of the four determination techniques (Table 4-2). The radiation technique had the greatest in-field efficiency (6 minutes per sample) while the frame was the lowest at 27 minutes per sample with the polyurethane foam and sand-cone techniques being intermediate between the two. Overall the infield efficiency ranged from 345 to 1605 seconds for the four determination techniques. The in- 
field efficiency for the weathered brown sandstone substrates was significantly lower than the unweathered gray sandstone substrates while the unmined native forest was not significantly different than both sandstone substrates (Table 4-2). This was due to the more rocky nature of the gray sandstone compared to brown sandstone. The unmined native forest soil had rocks and roots which slowed the measurements.

\section{$\underline{\text { Summary and Conclusion }}$}

The frame, polyurethane foam, and radiation determination techniques all produced similar results in the sandstone substrates and unmined native forest, and showed comparable results to other studies suggesting that all three techniques would provide accurate measurements of bulk density. The significantly lower bulk density results for the sand-cone technique could have been due to rock fragment content ( 40 to $50 \%$ in the brown sandstone and $63 \%$ in the gray) and an uneven surface found in the sandstone substrates. This could have allowed a greater volume of sand to fill the excavated area and the void space between the base of the sand-cone metal template and the ground surface. This discrepancy would have increased the volume of sand used to fill the hole which would have resulted in a greater volume of material than what was excavated, which would lead to lower bulk density measurements. As expected, the unmined native forest substrate had a lower bulk density than the four sandstone substrates.

Each determination technique was significantly different in respect to in-field efficiency and each technique has its own benefits and drawbacks. The frame technique allows the sampling of a large volume of material which could lower the amount of error associated with sampling, but that larger sample requires a greater amount of time to collect while in the field. Although the polyurethane foam technique in-field efficiency was intermediate in time recorded, the foam must cure for eight hours or be left over night and collected the following day. The 
added versatility of being able to use the polyurethane foam on sloping and uneven areas is a benefit but additional time to return and collect the foam molds is necessary. The sand-cone technique is fairly efficient in the field and can be completed all at one time, but it cannot be used on sloping areas nor on areas with great amounts of rock fragments protruding from the ground surface since the metal base plate must be flush with the soil surface to get accurate results. The radiation technique required the shortest time of the four techniques and allows for a greater number of samples to be measured in a set period of time. It, however, requires expensive equipment, training, and certification to properly execute the technique. 


\section{CHAPTER 5. LITERATURE CITED}

American Society for Testing and Materials. 1999. Standard test methods for density of soil and soil aggregate in place by nuclear methods (shallow depth). D 2922-96. Annual Book of ASTM Standards (I), Vol. 04.08:271-275. ASTM, Philadelphia, PA.

Andrews, J.A., J.E. Johnson, J.L. Torbert, J.A. Burger, and D.L. Kelting. 1998. Minesoil and site properties associated with early height growth of eastern white pine. J. Environ. Qual. 27:192-199.

Angel, P., V. Davis, J. Burger, D. Graves, and C. Zipper. 2005. The Appalachian Regional Reforestation Initiative. Office of Surface Mining. Washington, D.C.

Angel, P.N., D.H. Graves, C. Barton, R.C. Warner, P.W. Conrad, R.J. Sweigard, and C. Agouridis. 2006. Surface mine reforestation research: evaluation of tree response to low compaction reclamation techniques. p. 45-58. In R.I. Barnhisel (ed.) Proc. $7^{\text {th }}$ International conference on acid rock drainage (ICARD), St. Louis, MO. 26-30 March 2006. American Society of Mining and Reclamation (ASMR). Lexington, KY.

Angel, P.N., C.D. Barton, R.C. Warner, C. Agouridis, T. Taylor, and S.L. Hall. 2008. Forest establishment and water quality characteristics as influenced by spoil type on a loosegraded surface mine in eastern Kentucky. p. 28-65. In R.I. Barnhisel (ed.) Proc. of National Meeting of the American Society of Mining and Reclamation, New opportunities to apply our science, Richmond, VA. June 14-19. American Society of Mining and Reclamation, Lexington, KY.

Ashby, W.C. 1997. Soil ripping and herbicides enhance tree and shrub restoration of stripmines. Restoration Ecology. vol. 5. 2:169-177.

Beck, D.E. 1990. Liriodendron tulipifera L., yellow-poplar. In: Silvics of North America, Vol. 2, Hardwoods, R.M. Burns and B.H. Honkala (eds.) USDA For. Serv. Agric. Handb. 654:406-416.

Blake, G.R., and K.H. Hartge. 1986. Bulk density. p. 363-374. In A. Klute (ed.) Methods of soil analysis. Part 1. Agron. Monogr. 9. $2^{\text {nd }}$ ed. ASA and SSSA, Madison, WI.

Bower, C.A., and L.V. Wilcox. 1965. Soluble salts. In Methods of soil analysis, part 2. C.A. Black editor. ASA, Madison, WI.

Brady, N.C., and R.R. Weil. 2002. The nature and properties of soil. Thirteenth edition. Pearson Education, Inc. Upper Saddle River, New Jersey.

Bureau of Economical Analysis. 2009. Gross domestic product by state. Available at http://www.bea.gov/regional/gsp (Verified August 02, 2010). Bureau of Economical Analysis, Washington, DC. 
Burger, J.A., and C.E Zipper. 2002. How to restore forests on surface mined land. Virginia Coop. Ext. Serv. Publ. no. 460-123, Blacksburg, VA.

Burger, J., D. Graves, P. Angel, V. Davis, and C. Zipper. 2005a. The forestry reclamation approach. Office of Surface Mining. Washington, D.C.

Burger, J.A., D.O. Mitchem, C.E. Zipper, and R. Williams. 2005b. Herbaceous ground cover effects on native hardwoods planted on mined land. p. 136-145. In R.I. Barnhisel (ed.) Proc. of National Meeting of the American Society of Mining and Reclamation, New opportunities to apply our science, Richmond, VA. June 14-19. American Society of Mining and Reclamation, Lexington, KY.

Burger, J.A, D. Mitchem, and W.L. Daniels. 2007. Red oak seedling response to different topsoil substitutes after five years. In: Proc., 2007 American Society of Mining and Reclamation Meet. Gillette, WY. 2-7 June 2007. R.I. Barnhisel (ed.) ASMR, Lexington, KY.

Burger, J.A., D.O. Mitchem, C.E. Zipper, and R. Williams. 2008. Hardwood reforestation for phase III bond release: need for reduced ground cover. p. 192-205. In R.I. Barnhisel (ed.) Proc. of National Meeting of the American Society of Mining and Reclamation, New opportunities to apply our science, Richmond, VA. June 14-19. American Society of Mining and Reclamation, Lexington, KY.

Burger, J., V. Davis, J. Franklin, C. Zipper, J. Skousen, C Barton, and P. Angel. 2009. Treecompatible ground covers for reforestation and erosion control. Office of Surface Mining. Washington, D.C.

Bussler, B.H., W.R. Byrnes, P.E. Pope, and W.R. Chaney. 1984. Properties of minesoil reclaimed for forest land use. Soil Sci. Soc. Am. J. 48:178-184.

Casselman, C.N., T.R. Fox, J.A. Burger, A.T. Jones, and J.M. Galbraith. 2006. Effects of silvicultural treatments on survival and growth of trees planted on reclaimed mined land in Appalachians. For. Eco. and Man. Vol. 223. Iss. 1-3. pg 403-414.

Chaney, W.R., P.E. Pope, and W.R. Byrnes. 1995. Tree survival and growth on land reclaimed in accordance with Public Law 95-87. J. Environ. Qual. 24:630-634.

Conrad, P.W., R.J. Sweigard, V, Badaker, D.H., Graves, and C.D. Barton. 2008. The impact of surface applied mulches on selected physical properties of reclaimed mountaintop removal sites. International Journal of Mining, Reclamation, and Environment. 22:3 222236

Core, E. 1959. Common forest trees of West Virginia. Mathews Printing and Lithographing Company, Charleston, West Virginia. 112pp.

Cummins, D.G., W.T. Plass, and C.E. Gentry. 1965. Chemical and physical properties of spoil banks in the eastern Kentucky coal fields. U.S. Dept. of Agric., Forest Serv. Res. Paper. CS-17 
Demars, K.R., R.P. Long, and J.R. Ives. 2000. Use of wood waste materials for erosion control. New England Transportation Consortium. Technical Report. Project No. 97-3

Dickson, J.G. 1990. Cercis canadensis L., eastern redbud. In: Silvics of North America, Vol. 2, Hardwoods, R.M. Burns and B.H. Honkala (eds.) USDA For. Serv. Agric. Handb. 654:266-269.

Emerson, P., J. Skousen, and P. Ziemkiewicz. 2009. Survival and growth of hardwoods in brown versus gray sandstone on a surface mine in West Virginia. J. Environ. Qual. 38:18211829

Falk, B. 1997. Opportunities for the woodwaste resource. Forest Products Journal. 47: 17-22

Fields-Johnson, C., C.E. Zipper, D. Evans, T.R. Fox, and J.A. Burger. 2008. Fourth-year tree response to three levels of silvicultural input on mined lands. p. 389-404. In R.I. Barnhisel (ed.) Proc. of National Meeting of the American Society of Mining and Reclamation, New opportunities to apply our science, Richmond, VA. June 14-19. American Society of Mining and Reclamation, Lexington, KY.

Fisher, R.F., and D. Binkley. 2000. Ecology and management of forest soils. John Wiley and Sons, Inc. New York, New York. 489pp.

French, M.E., C.D. Barton, D. Graves, P.N. Angel, and F.V. Hebard. 2007. Evaluation of mine spoil suitability for the introduction of American chestnut hybrids in the Cumberland Plateau. p. 249-258. In R.I. Barnhisel (ed.) Proc. of National Meeting of the American Society of Mining and Reclamation, 30 years of SMCRA and beyond, Gillette, WY. June 2-7, 2007. American Society of Mining and Reclamation, Lexington, KY.

Fralish, J.S., and S.B. Franklin. 2002. Taxonomy and ecology of woody plants in North American forests (excluding Mexico and subtropical Florida). John Wiley \& Sons, Inc., New York, New York. 612pp.

Godman, R.M. 1965. Sugar maple, Acer saccharum Marsh. In: Silvics of forest tress of the United States. H.A. Fowells, comp. USDA. Agric. Handb. 271:66-73.

Godman, R.M., H.W. Yawney, and C.H. Tubbs. 1990. Acer saccharum Marsh., sugar maple. In: Silvics of North America, Vol. 2, Hardwoods, R.M. Burns and B.H. Honkala (eds.) USDA For. Serv. Agric. Handb. 654:78-91.

Groninger, J., J. Skousen, P. Angel, C. Barton, J. Burger, and C. Zipper. 2007. Mine reclamation practices to enhance forest development through natural succession. The Appalachian Regional Reforestation Initiative. Office of Surface Mining. Washington, D.C.

Grossman, R.B. and T.G. Reinsch. 2002. Bulk density and linear extensibility. In Methods of Soil Analysis, Part 4, Physical Methods. Soil Science Society of America. Madison, WI. 
Haering, K.C., W.L. Daniels, and J.A. Roberts. 1993. Changes in mine soil properties resulting from overburden weathering. J. Environ. Qual. 22:194-200.

Haering, K.C., W.L. Daniels, and J.M. Galbraith. 2004. Appalachian mine soil morphology and properties: effects of weathering and mining method. Soil Sci. Soc. Am. J. 68:1315-1325.

Harlow, W.M. 1935a. The dendrology of the more important trees of the United States, Part I hardwoods. Edwards Brothers, Inc., Ann Arbor, Michigan. 111pp.

Harlow, W.M. 1935b. The dendrology of the more important trees of the United States, Part II softwoods. Edwards Brothers, Inc., Ann Arbor, Michigan. 111pp.

Havlin, J.L, J.D.Beaton, S.L.Tisdale, and W.L.Nelson. 2005. Soil fertility and fertilizers. Pearson Education, Inc. Upper Saddle River, New Jersey. p515

Hicks, R.R. Jr. 1998. Ecology and management of central hardwood forests. Wiley, New York, USA. 368pp.

Hough, R.B. 1936. Handbook of the trees of the northern states and Canada east of the Rocky Mountains. Romeyn B. Hough Company, Lowville, New York. 470pp.

Huntley, J.C. 1990. Robinia pseudoacacia L.,Black locust. In: Silvics of North America, Vol. 2, Hardwoods, R.M. Burns and B.H. Honkala (eds.) USDA For. Serv. Agric. Handb. 654:755-761.

King, J. and J. Skousen. 2003. Tree survival on a mountaintop surface mine in West Virginia. p. 563-574. In R.I. Barnhisel (ed.) Proc. of National Meeting of the American Society of Mining and Reclamation and $9^{\text {th }}$ Billings land reclamation symposium, Billings, MT. June 3-6, 2006. American Society of Mining and Reclamation.

Larson, M.M., and J.P. Vimmerstedt. 1983. Evaluation of 30-year-old plantations on strip-mined land in east central Ohio. Ohio Agric. Res. and Develop. Center. Res. Bull. 1149.

Marquis, D.A. 1990. Prunus serotina Ehrh., black cherry. In: Silvics of North America, Vol. 2, Hardwoods, R.M. Burns and B.H. Honkala (eds.) USDA For. Serv. Agric. Handb. 654:594-604.

McLemore, B.F. 1990. Cornus florida L., flowering dogwood. In: Silvics of North America Vol. 2, Hardwoods, R.M. Burns and B.H. Honkala (eds.) USDA For. Serv. Agric. Handb. 654:279-283.

Mehlich, A. 1953. Short test methods used in soil testing division. Department of Agriculture, Raleigh, North Carolina. STDP No. 1-53. 
Michels, A., C. Barton, T. Cushing, P. Angel, R. Sweigard, and D. Graves. 2007. Evaluation of low spoil compaction techniques for hardwood fort establishment on an eastern Kentucky surface mine. p. 492-503. In R.I. Barnhisel (ed.) Proc. of National Meeting of the American Society of Mining and Reclamation, 30 years of SMCRA and beyond, Gillette, WY. June 2-7, 2007. American Society of Mining and Reclamation, Lexington, KY.

Mueller, R.N., and M.E. Hamilton. 1992. A simple effective method for determining the bulk density of stony soils. Commum. Soil Sci. Plant. Anal. 23:313-319

Norland, M.R. 2000. Use of mulches and soil stabilizers for land reclamation.. p. 645-666. In Reclamation of drastically disturbed lands. (eds R.I. Barnhisel, R.G. Darmody, and W.L. Daniels). American Society of Agronomy, Madison, WI.

Page-Dumroese, D.S., M.F. Jurgensen, R.E. Brown, and G.D. Mroz. 1999. Comparison of methods for determining bulk density of rocky forest soils. Soil Sci. Soc. Am. J. 63:379383

Plass, W.T. 1982. Organic and inorganic amendments affect vegetation growth on an acidic minesoil. Broomall (PA): USDA Forest Service Northeastern Forest Experiment Station. Research Paper NE-502.

Preston, R.J. Jr. 1989. North American Trees. Iowa State University Press, Ames, Iowa. 407pp.

Ringe, J.M. 1988. Economic aspects of sawmill residue use for tree seedling establishment on surface mines. International Journal of Mining, Reclamation and Environment. 2:3 129133.

Ringe, J.M., D.H. Graves, and J.W. Stringer. 1989. Economics of sawmill residue in the establishment of black locust plantations on surface mines. International Journal of Mining, Reclamation, and Environment. 3:4 201-205

Rizza, J., J. Franklin, and D. Buckley. 2007. The influence of different ground cover treatments on the growth and survival of tree seedlings on remined sites in Eastern Tennessee. p. 663-677. In R.I. Barnhisel (ed.) Proc. of National Meeting of the American Society of Mining and Reclamation, 30 years of SMCRA and beyond, Gillette, WY. June 2-7, 2007. American Society of Mining and Reclamation, Lexington, KY.

Rodrigue, J.A., and J.A. Burger. 2004. Forest soil productivity of mined land in the midwestern and eastern coalfield regions. Soil Sci. Soc. Am. J. 68:833-844.

Rogers, R. 1990. Quercus alba L., white oak. In: Silvics of North America, Vol. 2, Hardwoods, R.M. Burns and B.H. Honkala (eds.) USDA For. Serv. Agric. Handb. 654:605-613.

Sander, I.L. 1990. Quercus rubra L., northern red oak. In: Silvics of North America, Vol. 2, Hardwoods, R.M. Burns and B.H. Honkala (eds.) USDA For. Serv. Agric. Handb. 654:727-733. 
Schlesinger, R.C. 1990. Fraxinus americana L., white ash. In: Silvics of North America, Vol. 2, Hardwoods, R.M. Burns and B.H. Honkala (eds.) USDA For. Serv. Agric. Handb. 654:333-338.

Schoenholtz, S.H., J.A. Burger, and R.E. Kreh. 1992. Fertilizer and organic amendments effects on mine soil properties and revegetation success. Soil Sci. Soc. Am. J. 56:1177-1184.

Showalter, J.M., J.A. Burger, and C.E. Zipper. 2010. Hardwood seedling growth on different mine spoil types with and without topsoil amendment. J. Environ. Qual.39:483-491.

Showalter, J.M., J.A. Burger, C.E. Zipper, J.M. Galbraith, P.F. Donavan. 2007. Influence of mine soil properties on white oak seedling growth: a proposed mine soil classification model. South J. Appl. For. 31(2):99-107.

Skousen, J., and P. Emerson. 2010. Release of nutrients from brown and gray sandstone soil substitutes in southern West Virginia. p. 1135-1143. In R.I. Barnhisel (ed.) Proc. of National Meeting of the American Society of Mining and Reclamation, Bridging Reclamation, Science and the Community, Pittsburgh, PA. June 5-11. American Society of Mining and Reclamation, Lexington, KY.

Skousen, J., J. Gorman, E. Pena-Yewtukhiw, J. King, J. Stewart, P. Emerson, and C. DeLong. 2009. Hardwood tree survival in heavy ground cover on reclaimed land in West Virginia: mowing and ripping effects. J. Environ. Qual. 38:1400-1409.

Skousen, J.G., P. Ziemkiewicz, and C. Venable. 2006. Tree recruitment and growth on 20-yearold, unreclaimed surface mined lands in West Virginia. Int. J. of Mining, Recl. and Environ. vol. 20, No. 2, June 2006, 142-154.

Skousen, J., and C.E. Zipper. 2009. Revegetation species and practices. Virginia Coop. Ext. Serv. Publ. no. 460-122, Blacksburg, VA.

Sweigard, R., J. Burger, C. Zipper, J. Skousen, C. Barton, and P. Angel. 2007a. Low compaction grading to enhance reforestation success on coal surface mines. Office of Surface Mining. Washington, D.C.

Surface Mining Control and Reclamation Act. 1977. Public Law 95-87. U.S. Congress, Washington, DC.

Torbert, J.L., and J.A. Burger. 1990. Tree survival and growth on graded and ungraded minesoil. Tree planters' notes 41(2)3-5.

Torbert, J.L., and J.A. Burger. 2000. Forest land reclamation. p. 371-398. In Reclamation of drastically disturbed lands. (eds R.I. Barnhisel, R.G. Darmody, and W.L. Daniels). American Society of Agronomy, Madison, WI. 
Torbert, J.L., J.A. Burger, J.N. Lien and S.H. Schoenholtz.1985. Results of a tree species trial on a recontoured surface mine in southwestern Virginia. Southern J. of Appl. For. 9:150153.

Torbert, J.L., J.A. Burger, S.H. Schoenholtz, and R.E. Kreh. 2000. Growth of three pine species after eleven years on reclaimed mine soils in Virginia. North J. Appl. For. 17(3):95-99.

Torbert J.L., J.A. Burger and W.L. Daniels. 1990. Pine growth variation associated with overburden rock type on a reclaimed surface mine in Virginia. J. Environ. Qual. 19:8892.

Wendel, G.W. and H.C. Smith. 1990. Pinus strobus L., eastern white pine. In: Silvics of North America, Vol. 1, Conifers, R.M. Burns and B.H. Honkala (eds.) USDA For. Serv. Agric. Handb. 654:476-488.

WVDEP. 2002. Title 38, Series 2, West Virginia Surface Mining Reclamation Rule.

West Virginia Forestry Association. 2008. "Forestry Facts." Available at http://www.wvfa.org/forestry-facts.html (Verified July 29, 2010). West Virginia Association, Ripley, WV.

West Virginia Office of Miners' Health Safety and Training. 2010. West Virginia Coal Mining Facts. Available at http://www.wvminesafety.org/wvcoalfacts.htm (Verified July 29, 2010). West Virginia Office of Miners' Health, Safety and Training, Charleston, WV.

Zeleznik, J.D., and J.G. Skousen. 1996. Survival of three tree species on old reclaimed surface mines in Ohio. J. Environ. Qual. Vol. 25, no. 6, pp. 1429-1435. 